\title{
حجية المصالح المرسلة وأثرها فى الفقه الإسلاهى
}

\author{
shel \\ د./ سليمان عبد الوهاب الشحات بدوى \\ مدرس أصول الفقه \\ بكليت الشريعت والقانونـ بتفهنا الأشراف
}




\section{المقدهة}

قسمت هذا البحث إلى مقدمة وفصلين،وخاتمة

أها المقدهة فهي تشتهل على الآتي :-

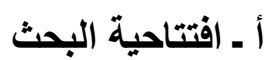

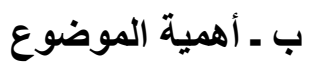

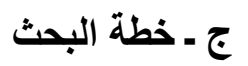

(أ) أنتاحية البحث

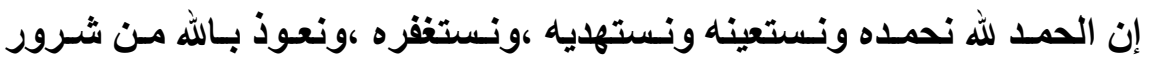

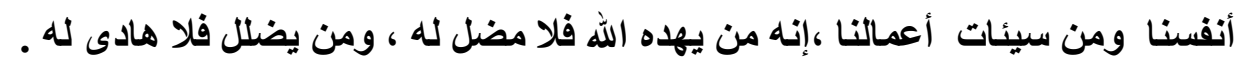

وأثشهـ أن لا الهه إلا الله وحده لا شريك لـه ،لـه الملك وله الحمد يحي ويميت

$$
\text { وهو على كل شيء قدير. }
$$

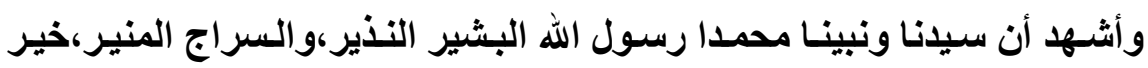

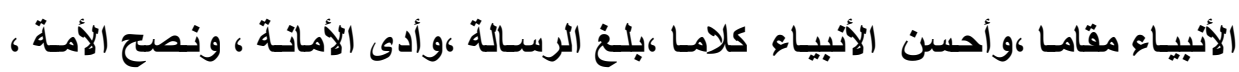

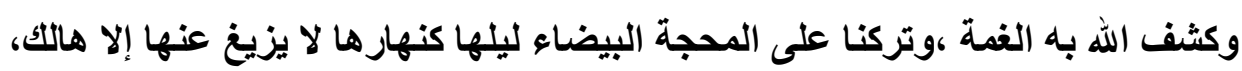
فا للهم صل وسلم وزد وبارك عليه وعلى آله وصحبه أجمعين .

(ب) أهمية الموضوع

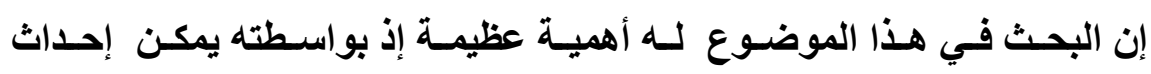
التشريعات والقوانين اللازمة بكل ما يستجد من وقائع في هذا العصر الذي نعيش فيه لهيه 
وخصوصا عند فقد الاليل الخاص من الكتاب أو السنة أو الإجماع أو القياس(')، وذلك

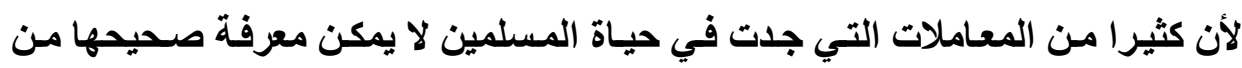
فاسدها إلا عن طريق المصالح المرسلة .

وبـالنظر في الشريعة الإسـلامية وجدنا أن الله عز وجل راعى فيها مصالح

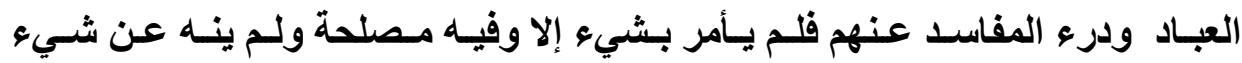

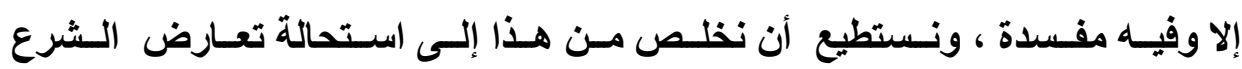

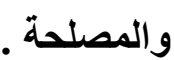

فأردت بيحثي هذا إثبات حجية المصالح المرسلة وأنها صالحة للاستلال

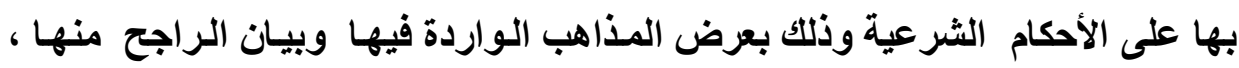
وبيان أثر هذا الخلاف في الفروع الفقهية ،سائلا المولى عز وجل النفع لي ولسائر المسلمين فهو ولى ذلك والقادر عليه .

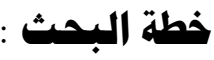

قسمت هذا الموضوع إلى مقدمة ،وثلاثة فصول ،وخاتمة. أما المقدمة فهي تثتمل على ما يأتي:-

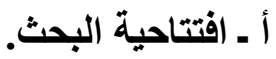
ب ـ أهمية الموضوع. ج - خطة البحث وهي كما يأتي: 
الفـصل الأول : تعريـف المسالح المرسـلة ، والفـرق بينها وبـين مايشتبه بهـا ،

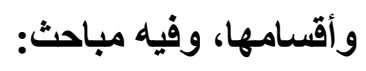

المبث الأول : تعريف المصلحة لغة واصطلاحا.

المبحث الثاني : الفرق بين المصلحة وما يثتبه بها ،وفيه مطلبان:

- المطلب الأول : الفرق بين المصلحة والقياس.

- المطلب الثاني : الفرق بين المصلحة والاستحسان.

المبحث الثالث : إطلاقات المصلحة وأسباب الأخذ بها وفيه مطلبان:

$$
\text { - المالب الأول : إطلاقات المصلحة. }
$$

- المطلب الثاني : أسباب الأخذ بالمصلحة.

المبحث الرابع : أقسام المصلحة ،وفيه مطالب:

- المطلب الأول : أقسام المصلحة باعتبار قوتها في ذاتها ،وفيه فرعان :

الفرع الأول : أقسام المصلحة باعتبار قوتها في ذاتها.

$$
\text { الفرع الثاني : متثمات مراتب المصالح. }
$$

- المطاسب الثـاني : أقسام المسصلحة مـن حيث العهوم والخصوص أو

$$
\text { الوضوح والخفاء. }
$$

- المطلب الثالث : أقسام المصلحة من حيث اعتبار الشارع لها أو عدم

$$
\text { اعتباره. }
$$


الفصل الثاني : حجية المصالح المرسلة ،وفيه مبحثان:

المبحث الأول : مذاهب العلماء في الاحتجاج بها.

المبحث الثاني : أدلة المذاهب وبيان المذهب الراجح.

الفصل الثالث : أثر الاحتجاج بالمصالح المرسلة في الفقه الإسلامي.

$$
\text { وفيه مباحث: }
$$

المبحث الأول: في العبادات.

المبحث الثاني: في المعاملات.

المبحث الثالث: في العقوبات.

الخاتمة : في أهم النتائج والتوصيات. 


\section{المبحث الأول}

\section{تعريف المسلمة لغة واصطلاها}

\section{أولاً :تعريف الملحة لغة :-}

المصلحة في اللغة تطلق بإطلاقين :

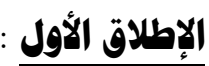

أنها كالمنفعة وزنساً ومعنى فهي بـذلك إمـا أن تكون مصدر بمعنى الصلاح كالمنفعة بمعنى النفع ،وإما اسم للواحدة من المصالح كالمنفعة اسم للواحدة في

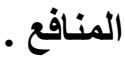

ويؤيد ذلك ما جاء في لسان العرب ما نصه :" والمصلحة الصلاح والمصلحة

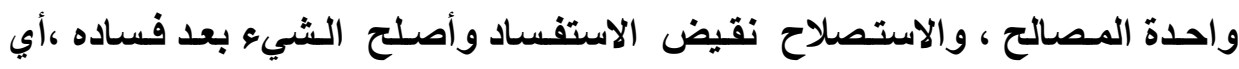
أقامه، وأصلح الدابة ،وأحسن إليها فصلحت(') و المنفعة هي اللذة تحصيلا أو إبقاءً ، و والمراد بالتحصيل جلبها وبالإبقاء المحافظة عليها.

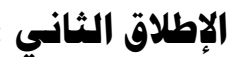

إنها تطلق على الفعل الذي فيهـ صـلاح بمعنى النفع مجازاً مرسـلا من بـاب إطلاق اسم المسبب على السبب فيقال التجارة مصلحة ، وطلب العلم مصلحة لأن

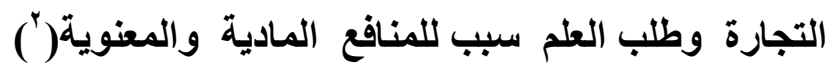

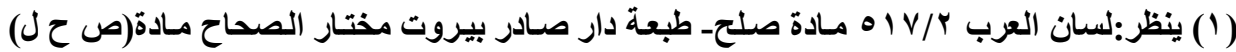

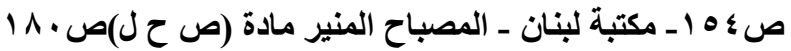

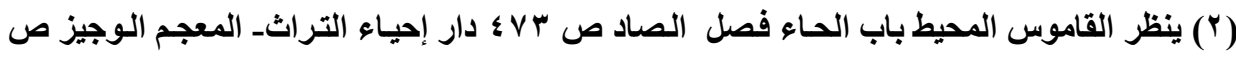

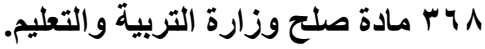

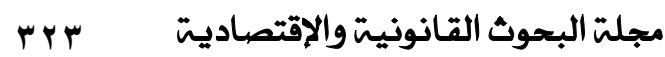




\section{ثانيا :تعريف المصلحة اصطلاحا:}

عرفها العلماء بتعريفات كثيرة تكاد أن تكون كلها متقاربة في المفنى فمن

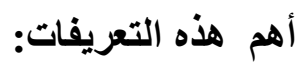

اـ تعريف الإهام الغزالي(') : قال " المصلحة هي عبارة في الأصل عن جلب منفعة

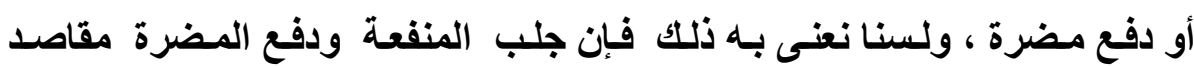
الخلق، وصلاح الخلق في تحصيل مقاصدهم ، لكنا نعنى بالمصلحة الححافظة على مقصود الثرع ومقصود الثرع من الخلق خمسة ، وهو أن يحفظ عليهم دينهم،ونفسهم ،وعقلهم ،ونسلهم ،ومسالهم فكل مسا يتضمن حفظ هذه الأصسول

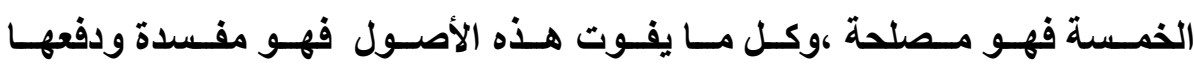

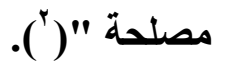

\section{ويؤخذ هن هذا التعريف أهران}

أحسدها : أن المصلحة في الأصل عبارة عن جلب منفعة أو دفع مضرة ، وهذا يتفق مع المعنى اللغوي للمصلحة كما سبق أن بيناه .

(1) الغزالي : هو محمد بن محمد بن أحمد حجة الإسلام زين العابدين الإمـا م أبو حامـ الغزالي،ولـا

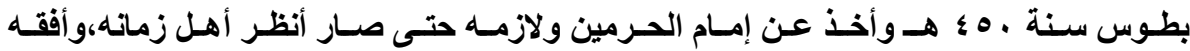

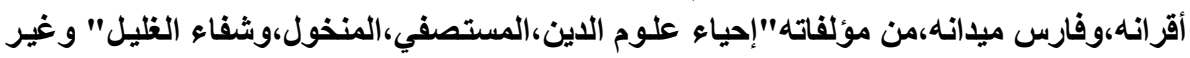

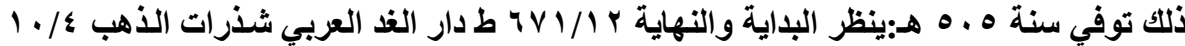

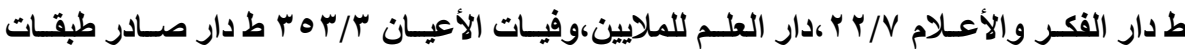

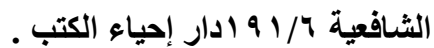

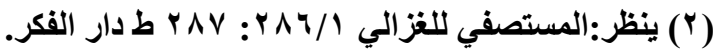


ثانيدهـا : أن الإمـام الغزالي حينمـا عرف المصلحة لـم يقصد المعنى العرفي ، وإنما قصد بها جلب النفع أو دفع ضرر مقصود للشارع ،ومعنى ذلك أن النساس قد يعتبر ون الأمر منفعة وهو في نظر الشارع مفسدة ،وقد يعتبرونه مفسدة وهو بنظر الثارع مصلحة ، فليس هناك تلازم بين المصلحة والمفسدة في عرف النساس وفي

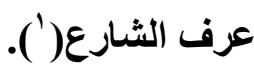
rـ تعريـف الإهـام السشاطبي (r) : قال:" وأعنى بالمصالح مـا يرجع إلى قيام حياة الإنسان ،وتمام عيشه ،ونيله ما تقتضيه أوصافه الثهوانية والعقلية على الإطلاق حتى يكون منعما على الإطلاق ،وهذا في مجرد الاعتياد لا يكون ،لأن تلك المصالح مشوبة بتكليف ومشاق قلت أو كثرت تقترن بها أو تسبقها أو تلحقها كالأكل والشرب واللبس والسكنى والركوب والنكاح وغير ذلكك ،فِان هذه الأمور لا تنال إلا بكد وتعبككما أن المفاسد الدنيوية ليست بمفاسد محضة من حيث مواقع الوجود ،إذ ما من مفسدة تفرض في العادة الجارية إلا ويقترن بها أو يسبقها أو يتبعها من الرفق واللطف ونيل اللذات كثير "(").

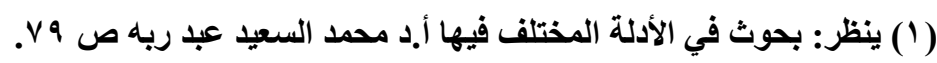

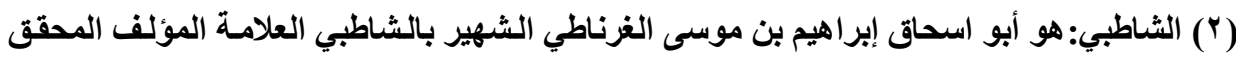

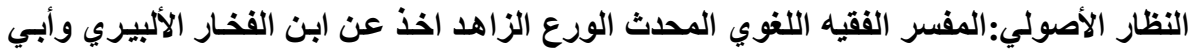

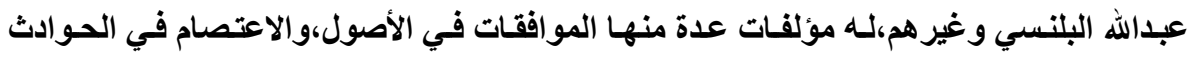

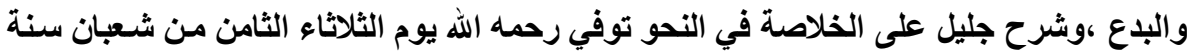

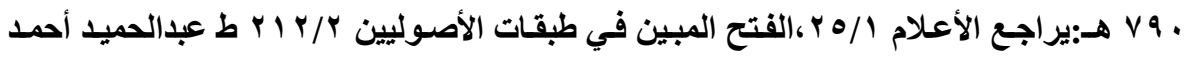




\section{ويؤخذ هن هذا التعريف أهران :-}

أحسدهما : أن الإمسام الشاطبى عرف المصلحة بمـا يتفق ومقصود الشارع

سواء كاتت في رتبة الضروري وفي رتبة الحاجى وفي رتبـة التحسينى كما هو واضح من النص السابق.

ثانيدهـــا : ويؤخـذ مـن هـا التعريـف أنسه لا توجـ مسصلحة خالـصة في

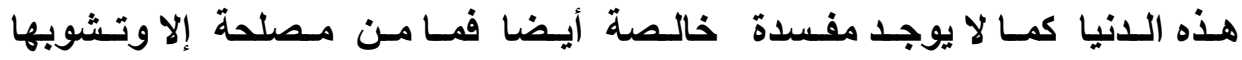
مفسدة ،ومـامن مفسدة إلاوتشوبها مصلحة، والعبرة إنمـاتكون للغالب ، وأخذ هذا من استقراء النصوص منها قولـه تعـالى "يسألونك عن الخمر والميسر قل فيهمـا إثم كبيز ومنـافع للنـاس وإثمهمـا أكبر من نفعهما"(') وسبب ذلك إن هذه الارار دار ابتلاء واختبار لقوله تعالى "الأي خلق الموت والحياة ليبلوكم أيكم أحسن

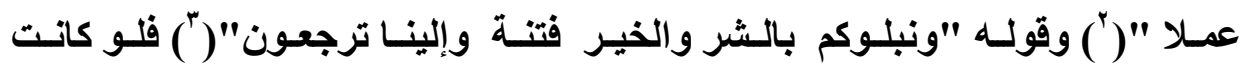
المصالح خالصة لما تركها الناس واتجروا وراء شهواتهم ولو كاتت المفاسد خالصة لما ارتكبها الناس وداسوا على عقولهم ، بخلاف الدار الآخرة فبان مصلحة فيها خالصة ، والمفسدة فيها كذلك لارتفاع التكليف فيها () 


\section{r- تعريف ابن قداهة") والطوفي": "المصلحة هى جلب نفع أو دفع ضرر "(")}

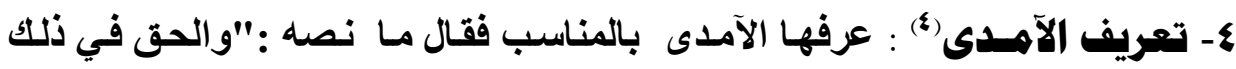
أن يقـال : المناسب عبـارة عن وصف ظـاهر منضبط يلزم مسن ترتيب الحكم

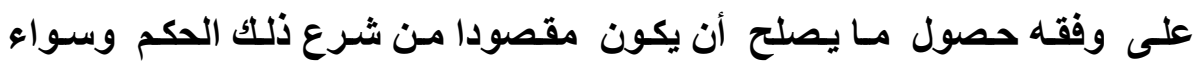

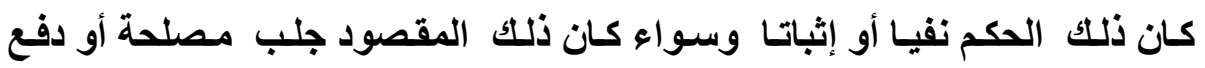

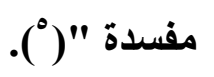

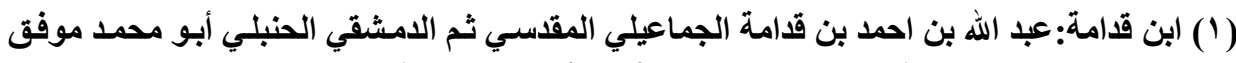

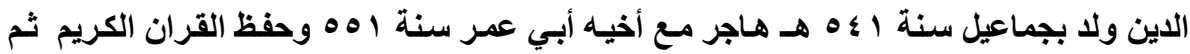

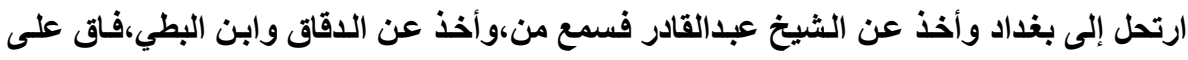

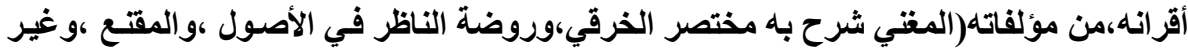

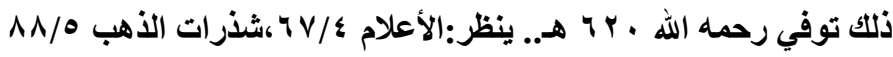

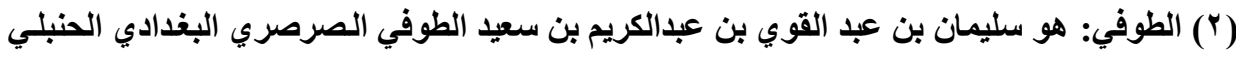

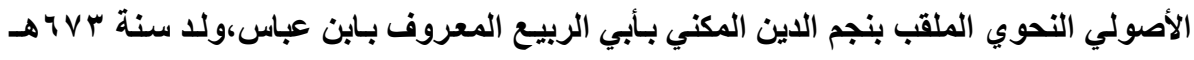

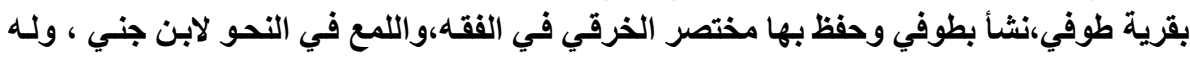

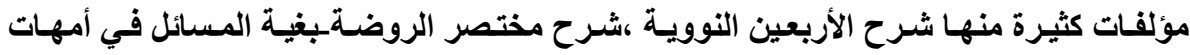

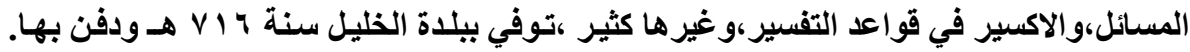

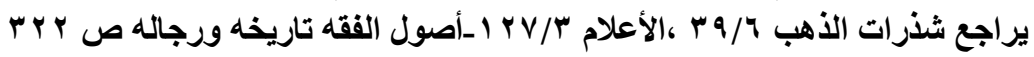

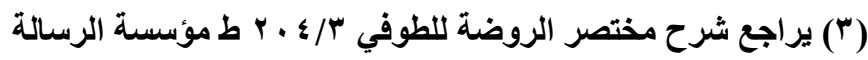

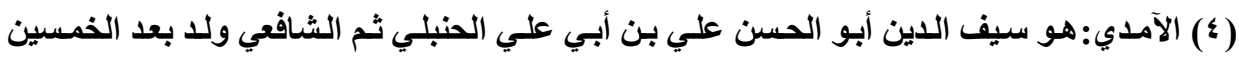

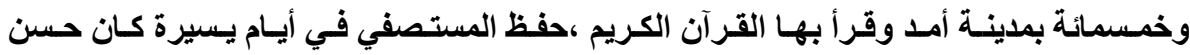

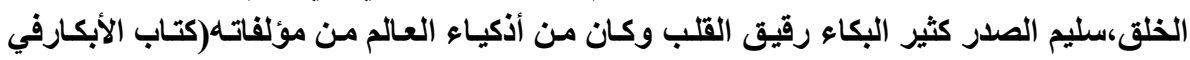

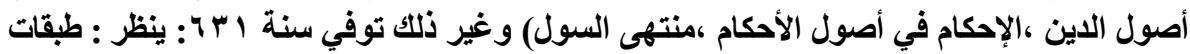

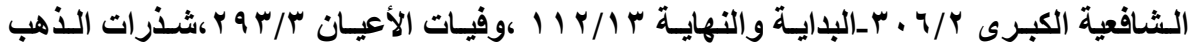


وبعد عرض هذه التعريفات نجد أنها كلها متقاربـة وكلها تدور حول معنى

واحـ وهـى جلب المنفعة للإنسـان ودفع المـرة عنـه ،وأن كل منفعـة قصدها

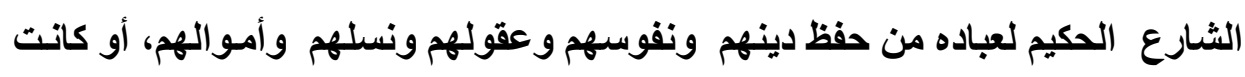

ملائمة لمقصوده إنما حصلت وفق شروط معينة. 


\title{
المبحث الثاني \\ الفرق بين المصلحة وها يشتبه بها وفيه هطابسان
}

\author{
المطاب الأول : الفرق بين المصلحة والقياس. \\ المالب الثاني : الفرق بين المصلحة والاستحسان.
}

\section{المطالب الأول}

\section{الفرق بين المسلحة والقياس}

بـالنظر في المصالح المرسلة والقيـاس نجد أنهما يتفقان في أمرين وأنهمـا

$$
\text { يختلفان في أمرين أما وجه الاتفاق:- }
$$

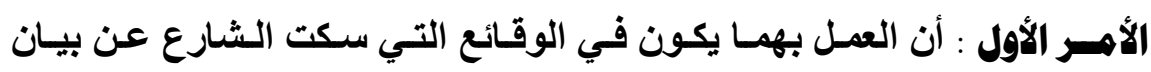

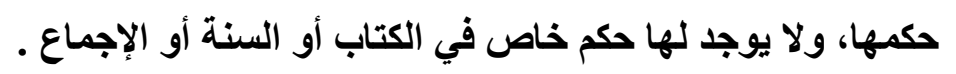

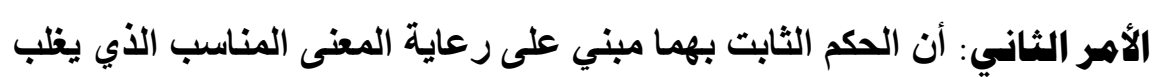

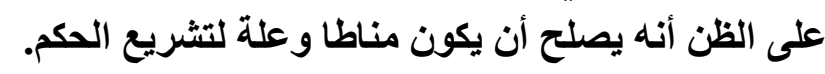

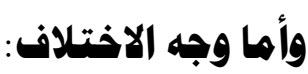

الأهر الأول : أن الوقائع التي يعمل فيها بالقياس لها لها نظير في الكتاب أو السنة

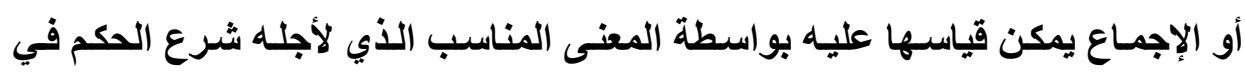

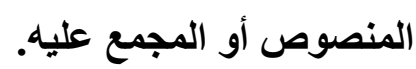

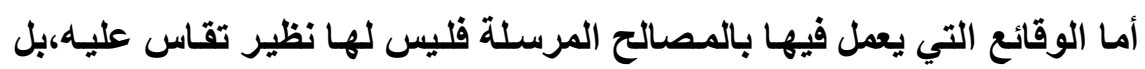

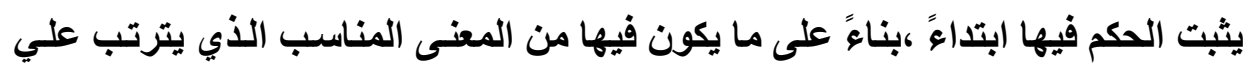
تثريع الحكم وبنائه عليه تحقيق مصلحة للناس أو دفع مفسدة عنه فهر. 
الأهر الثاني :أن المعنى المناسب الأي بني عليه الحكم في القياس قام الدليل

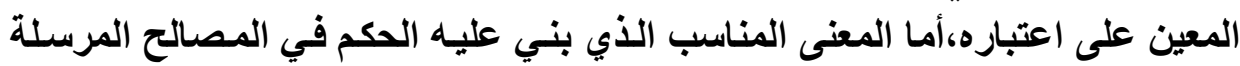

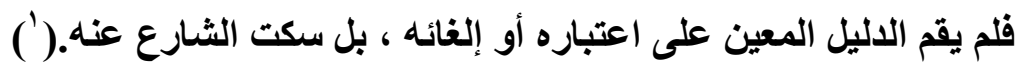

\section{المالب الثاني}

\section{الفرق بين الصالح المرسلة والاستحسان}

يككن التفرقة بينهما بان الاستحسان يقتضي أن يكون للمسألة التي يحكم بـه

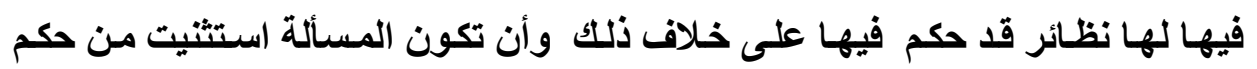

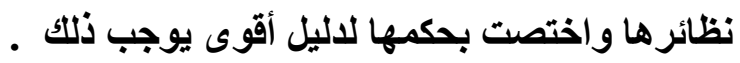

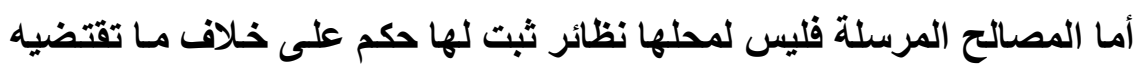
المصلحة في ذلك المحل بل الحكم فيه ثابت بها ابتداء.

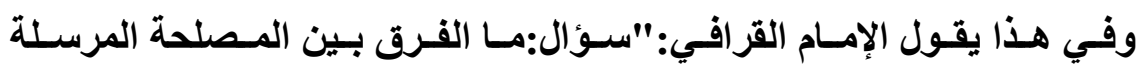

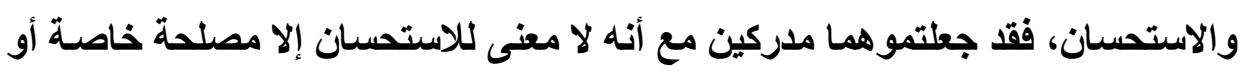
راجحة تقع في نفس الناظر.

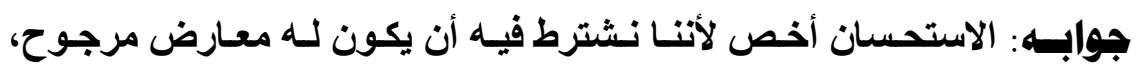

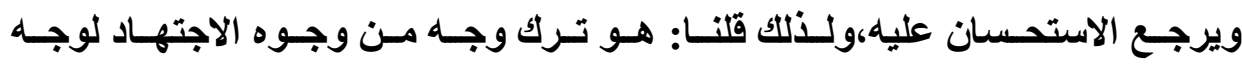

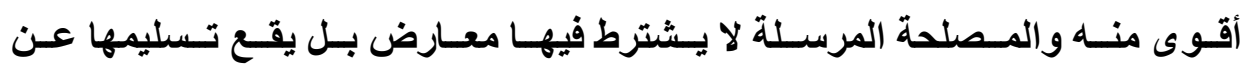

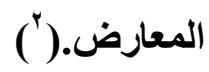

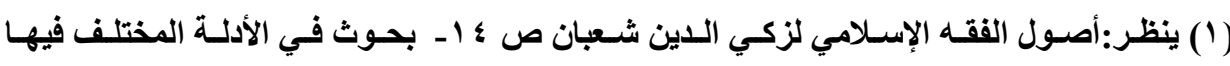

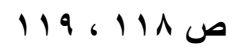

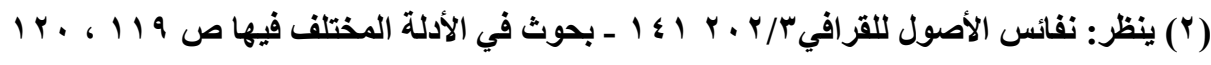

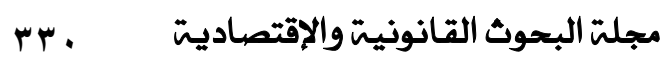




\section{المبحث الثالث}

\section{اطلاقات الملحة وأسباب الأخذ بها.}

\section{وفيه هطالبان :}

المطلب الأول : إطلاقات المصلحة

المالب الثاني : أسباب الأخذ بالمصالح :

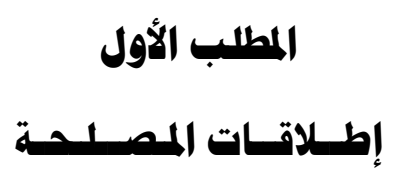

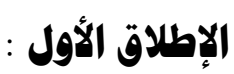

من العلمساء من أطلق على المصلحة المناسب المرسل(')،لأن ترتيب الحكم

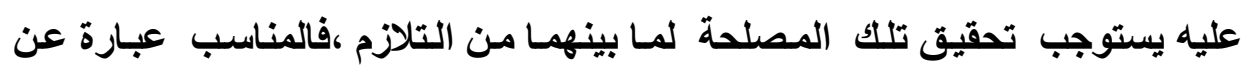
علة الحكم ،والمصلحة عبارة عن حكته ،فالحكم مترتب على علته ،والحكمة مترتبة على الحكم ،فإطلاق أحدهما يلازم إطلاق الأخر ويصاحبه(').

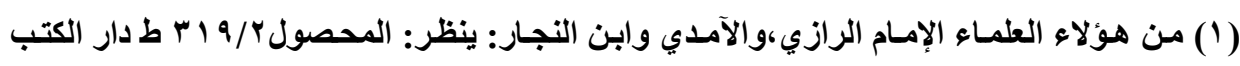

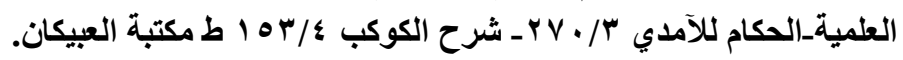

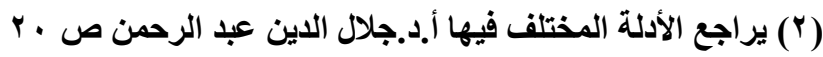

مجلتّ البحوث القانونيت والإقتصاديت اسب 
هذا وقد عرفه الآمدي(') "بأنه المناسب الذي لم يشهـ لـه أصل من أصول

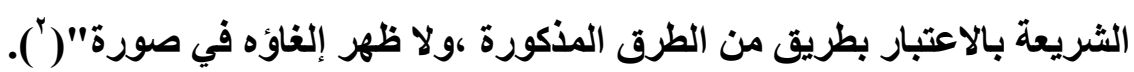
ـ وعرفه الغزالي(") :بأنه " مـالم يشهـ لـه الشرع بالبطلان ولا بالاعتبار نص

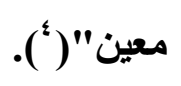

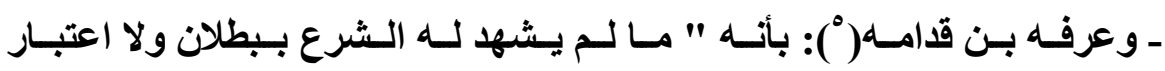

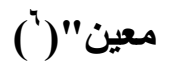

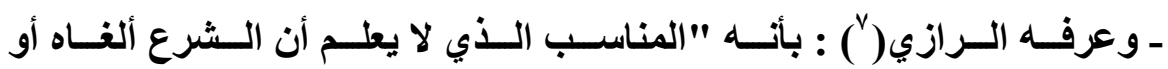

$$
\text { اعتبره"(). (1). }
$$

أما المحثثين من العلمـاء فقد عبروا عن المناسب المرسل بالمصالح المرسـلة ولهذا فقد عرفو ها بأنها عبارة عن المعاني التي يحصل من ربط الحكم بها وبنائه عليها

$$
\begin{aligned}
& \text { (1) (1) سبقت ترجمته ص (ب) } \\
& \text { r }
\end{aligned}
$$

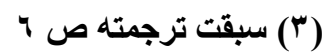

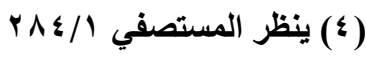

$$
\begin{aligned}
& \text { (0) سبقت ترجمته ص (2) }
\end{aligned}
$$

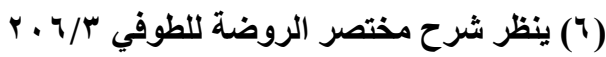

و (V) هو محمد بن عمر بن الحسن بن الحسين أبو عبد الله فخر الدين الرازي القرشي البكري التميمسي

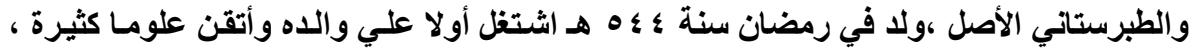

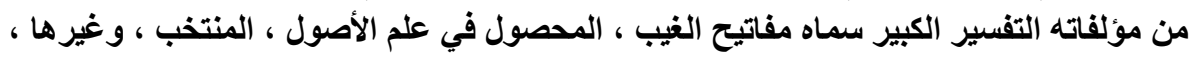

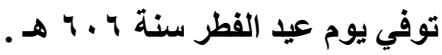

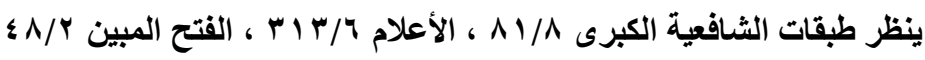

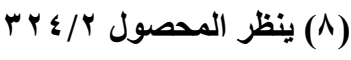


جلب مصلحة أو دفع مفسدة عن الخلق ولم يقم دليل معين من قبل الثارع يدل علي

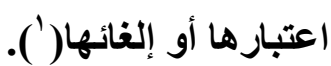

وبالنظر في هذه التعريفات نجد أنها كلها تدور حول مغنى واحد وهو المصالح

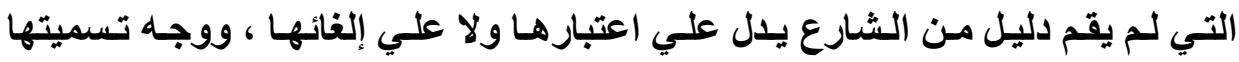

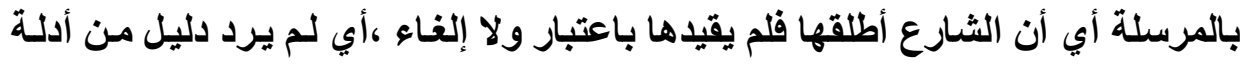

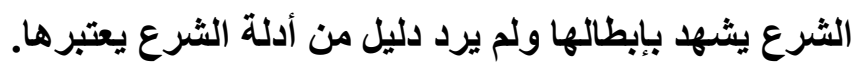
الإطسلاق الثـاني : مـن العلمـاء مـن يطلقون عليهـا الاستصلاح(') لأنسه طلب

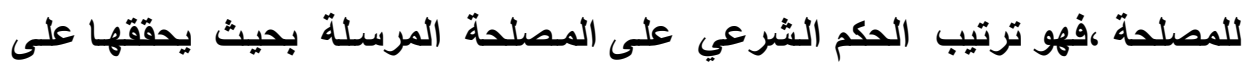

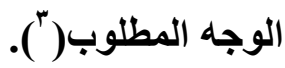

الإطلاق الثالث: من العلماء من يطلقون عليها الاستدلال(") ،ويراد به مـاكـان

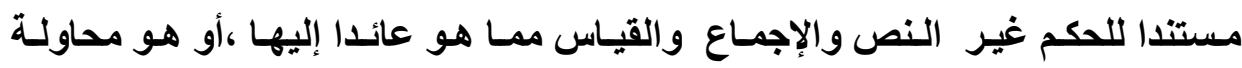
الدليل الثرعي من جهة القواعد لامن جهة الأدلة المعلومة . وحقيقته : الاجتهاد الثرعي في استتباط حكم لم ينص عليه بعينه.( )

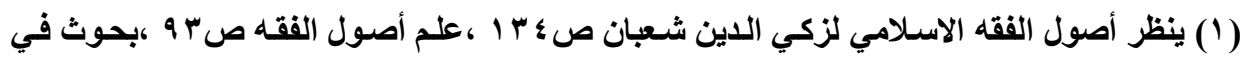

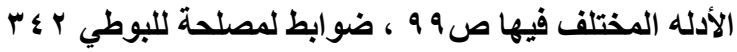

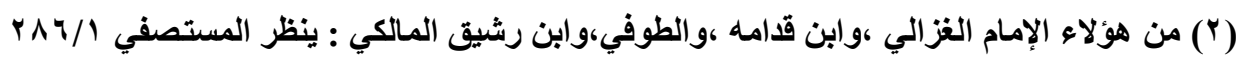

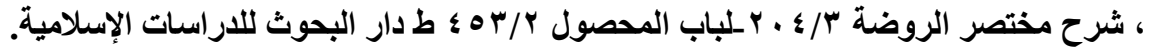

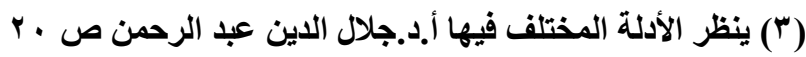

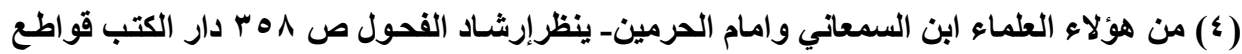

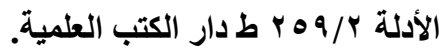

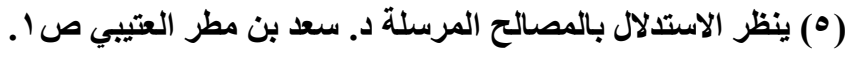




\section{الإطلب الثاني \\ أسباب الأخذ بالاصالح}

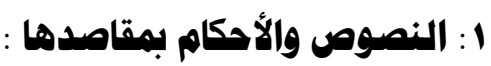

و هذا هو مـا عليه الجمهور خلافا للظاهرية ، ولكن الجمهور يتفاوت في مدى الجها الأخذ بهذا المبدأ ،وفي مدي الاطراد في العمل به والتفاوت بين الفقهاء أفرادا أكثر ممـا

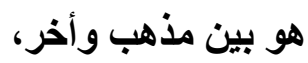

وكون النصوص والأحكام ينبغي أن تؤخذ بمقاصدها دون الوقوف عند ظواهرها

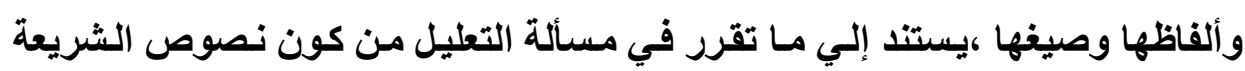
وأحكامها معللة بمصالح ومقاصد وضعت لأجلها ،فينبغي عدم إهمال تلكك المقاصد ولا الغفلة عنها عند تقريز الأحكام ، وعند النظر في النصوص وماصد ('). r l l الجمع بين الكليات العامة والأدلة الخاصة :

وأعني بالكليات العاهة : الكليات النصية ، والكليات الاستقرائية.

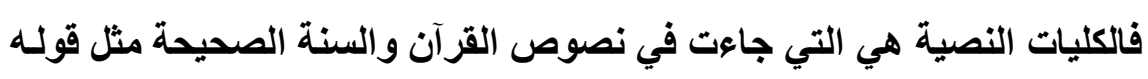

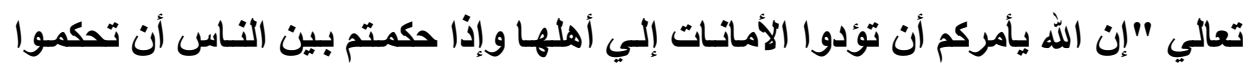

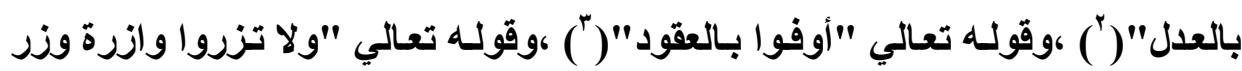
أخري"(") بالعد").

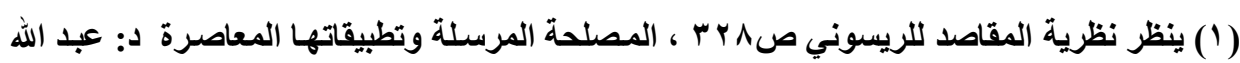

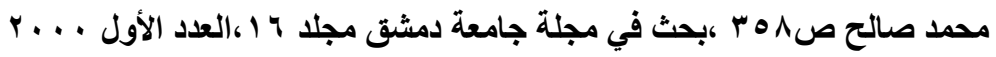

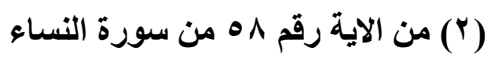

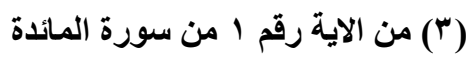

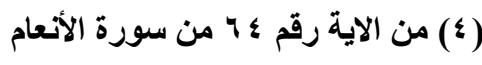


ومثل قولـه صلي الله عليه وسلم "لا ضرر ولا ضـرار "(') ،وقولـه صلـي الله

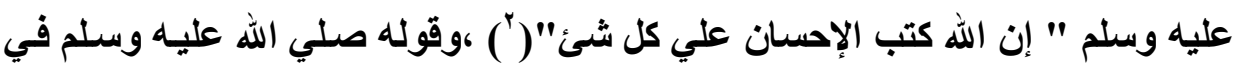

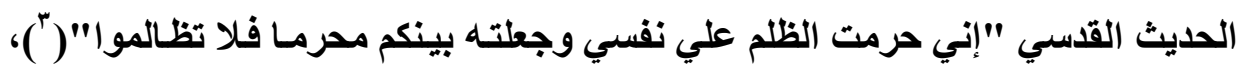
وقوله صلي الله عليه وسلم "إنما الأعمال بالنيات"( (4).

أها الكليات الاستقرائية: فهي التي يتوصل إليها عن طريق عدد من النصوص والأحكام الجزئية ،كحفظ الضروريات ،والحاجيات ،والتحسينات ،وسائر المقاصد العامة للشريعة والقواعد الفقهية الجامعة مثل "الضروريات تبيح المحظورات ،والمشقة

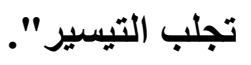

\section{وأعني بالأدلة الخاصة ،أو الأدلة الجزئيه :}

الأدلة الخاصة بمسائل معينة كأية كذا الدالة علي كذا ،أو الحديث الفلانس الدال

علي حكم المسألة الفلانية ،أو الأقيسة الجزئية.

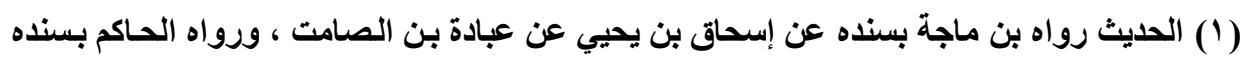

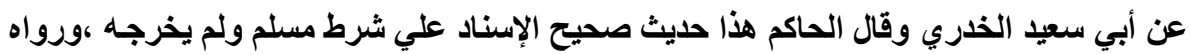

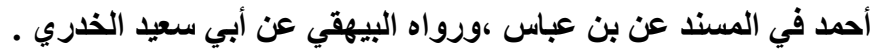

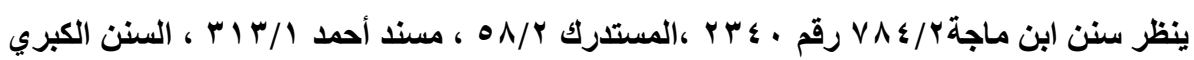

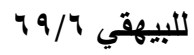

(Y) الحديث رواه الإمام مسلم في كتاب الصيد الأمر بإحسان الذبح وتحديد الثفرة ، ينظر صحيح مسلم

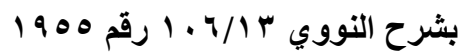

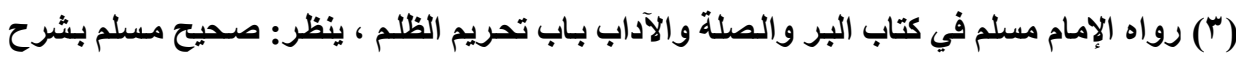

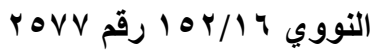

( ) الحديث رواه البخاري في كتاب بدء الوحي ،والإمام مسلم في كتاب الإمارة باب إنما الأعمال بالنية.

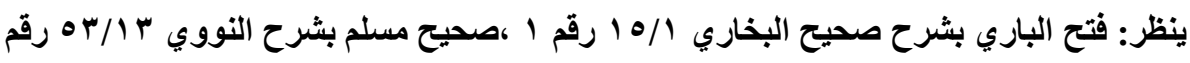




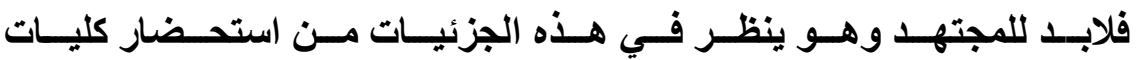
الثريعة الجزئية ،ومقاصدها العامـة ،وقواعدها الجامعة ، لابد من مراعـاة هذه وتلثك في أن واحد، ولابـ أن يكون الحكم مبنياً علي هذه وتلكا معـا ،أعني الأدلـة الكليـة ،

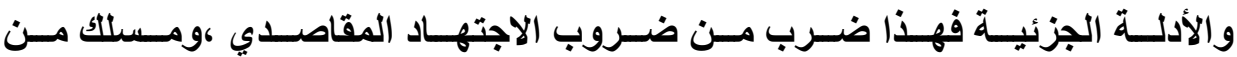

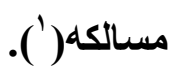

\section{r - جلب المسالح ودرs الإفاسد مطالقا :}

أي حيثما تحققت المصلحة فيجب العمل علي جلبها ورعايتها ،وحيثمـا تحققت المفسدة فيجب العمل علي دفعها وسد أبوابها ،وان لم يكن في ذلك نص خاص فحسبنا النصوص العامـة الواردة في الحث علي الصلاح والإصلاح والنفع والخير ،وحسبنـا النصوص العامـة في ذم الفساد والإفساد والمفسدين في النهـي عن الشر والضرر، وحسبنا الإجمـاع المنعقد علـي أن المقصد الأعم للشريعة هو جلب المـصالح ودرء المفاسد في العاجل والآجل.

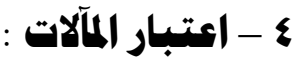

أي أن المجته حين يجته ويحكم ويفتي عليه أن يقدر مـآلات الأفعال التي هي محل حكمه ،وإفتائه وأن يقدر عواقب حكمـه وفتواه ،وألا يعتبر أن مهمته تتحصر في إعطاء الحكم الشرعي ،بل مهمته في الفعل وهو يستحضر مآله أو مآلاته ، وأن يصدر الحكم وهو ناظر إلي أثره أو آثاره ، فإذا لم يفعل فهو إمـا قاصر عن درجة الاجتهاد أو مقصر فيها. 
و هذا فرع عن كون الأحكام بمقاصدها ، فعلي المجتهذ الذي أقيم متكلما باسم

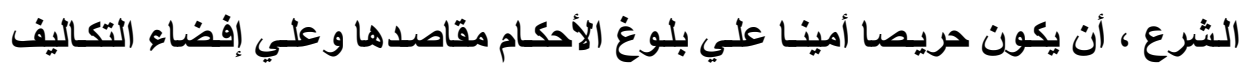

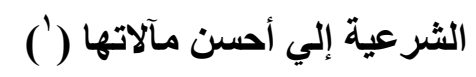

ويؤصل الإمـام الثشاطبي هذا الأصل بقولـه:" النظر في مـآلات الأفعال معتبر

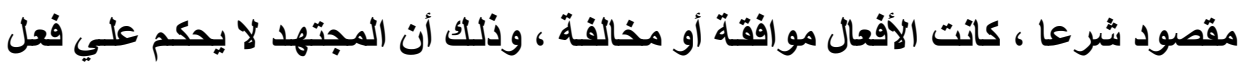

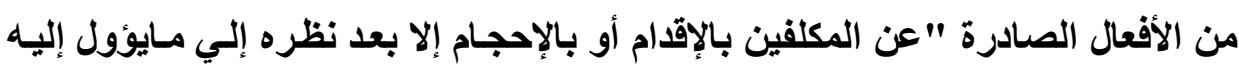

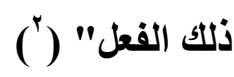




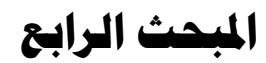

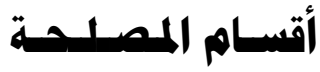

قسم الأصوليون المصلحة إلى تقسيمات عدة باعتبارات مختلفة وفيه مطالب:

\section{المطاب الأول}

أقسام المصلحة باعتبار قوتها في ذاتها وفيه فرعان :

\section{الفرع الأول}

أقسام المصلحة باعتبار قوتها في ذاتها. تنقسم المصلحة بهذا الاعتبار إلى ثلاثة أقسام :-

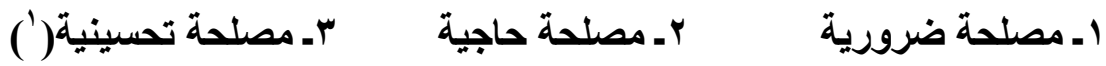
أها أما الصلحة الضرورية :

فمعناها إنها لابد منها في قيام مصالح الدين والدنيا بحيث إذا فقدت لـم تجر مصالح الانيا على استقامة بل على فساد وتهارج وفوت حيـاة ،وفي الآخرة فوت الات النجاة والنعيم، والرجوع بالخسران المبين .

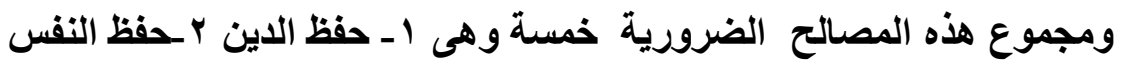
r- حفظ العقل ع ـ حفظ النسل ه ــ حفظ المال .

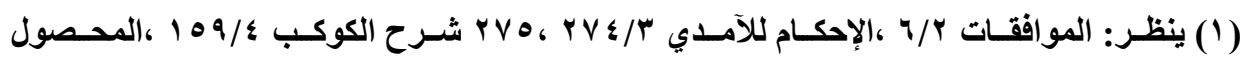

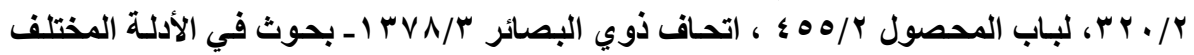

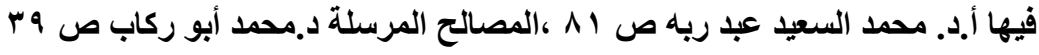




\section{1 - فهفظ الدين يكون بأهرين}

أحدهما :حفظه من جانب الوجود وذلكك بإقامة أركانـه وتثبيت قواعده ولذا

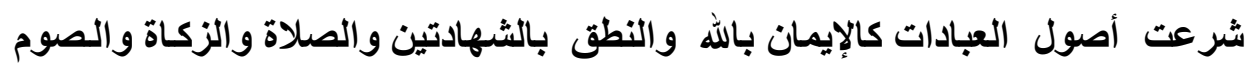
والحج.

ثانيهها: حفظه من جاتب العدم بمـا يدراً عنها الاختلال الواقع أو المتوقع

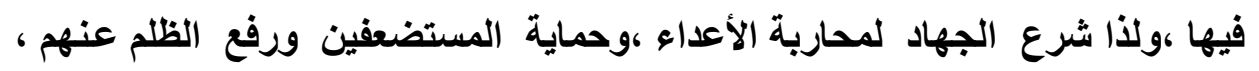
وشرعت العقوبات غير المقدرة لإيقاف فساد المبتدعة في الدين ( ('). r- حفظ النفس،وهذا يكون بأهرين:

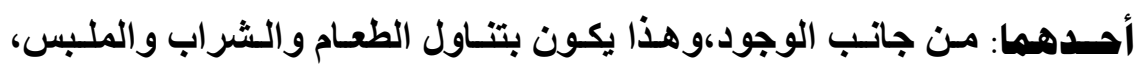
و المسكن مما يتوقف عليه بقاء الحياة،وصون الأبدان.

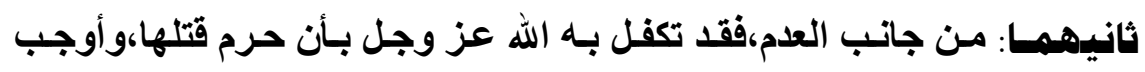

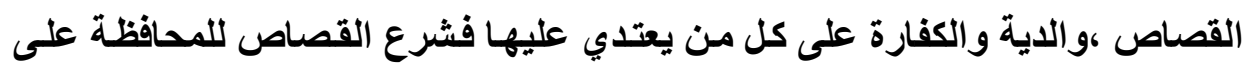

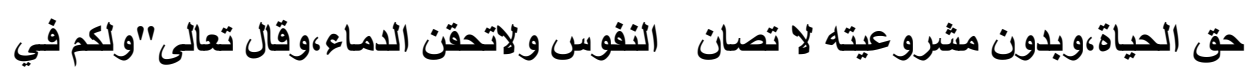

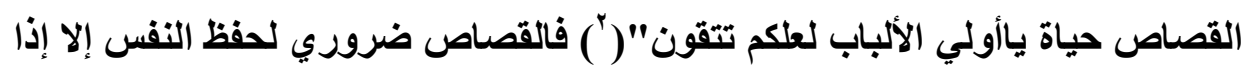
عفا أولياء الام عنه إلى الديات.

(1) (1) ينظر المراجع السابقة

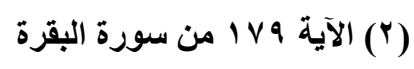

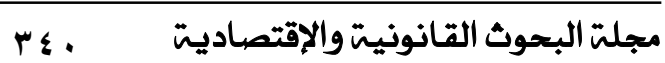




\section{r- مفظ العقل - ويكون بأهرين}

أحسهما : من جاتب الوجود،وذلكت بتوجيهه إلى النظر و التفكير والاستتنتاج

لقوله تعالى"أفلا ينظرون إلى الإبل كيف خلقت"(')وقولـه تعالى" أفلا يتدبرون القرآن

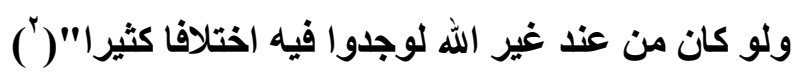
ثانيهها: من جانب العدم،وذلك بتحريم المسكرات،وإقامة العقوبـات عليها،ولذا

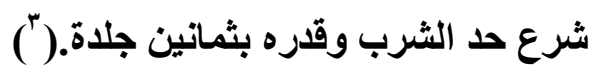

\section{§- حفظ النسل: ويكون بأهرين}

أحدهما: من جاتب الوجود،وذلك باباحة النكاح ،وأحكام الحضانة والنفقات لكي

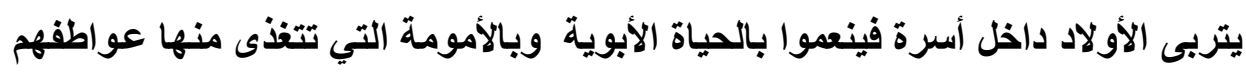

$$
\text { وتكمل مداركهק. }
$$

ثانيهها: من جانب العدم،وذلك بأن حرم الزنا وأوجب الحد على فاعله ومرتكبه

$$
\text { حفظا لهذه المصلحة من جانب العدم. }
$$

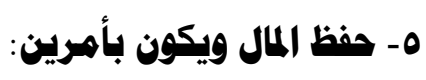

أحدهما: حفظه من جانب الوجود وذلك بإباحة المعاملات فقد شرعت لحماية

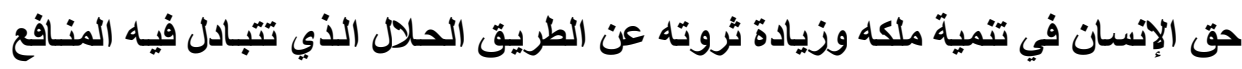
من غير ظلم ولاجور بما يعود عليه وعلى الجماعة بالخير والرفاهية،فالبيع والإجارة

$$
\begin{aligned}
& \text { (1) الآية VI المن سورة الغاشية }
\end{aligned}
$$

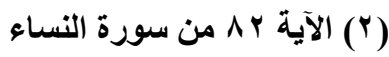

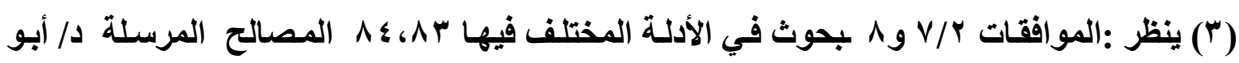

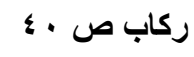


مثّلا من المصالح الضرورية لحفظ المال من جانب الوجود إذ بدونهما لايمكن تحصيل

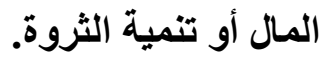

ثانيهها: حفظهما من جاتب العدم:فق شرع الله حد السرقة وهو القطع،وأوجب ضمان الثيء المغصوب،فالسرقة جريمة تعود على أصل هذه المصلحة بالإبطال،ولذلك التك كانت عقوبة السرقة ضرورية في حفظ هذا الحق وحماية تلك المصلحة ،وأمـا التضمين التصني

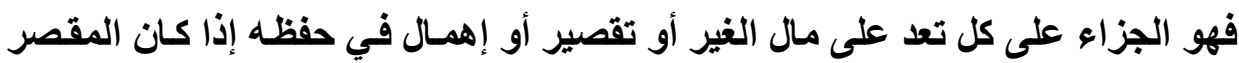

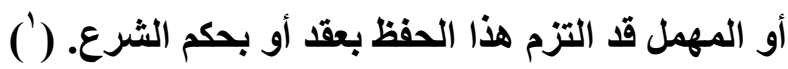

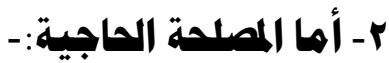
فمعناها إنها مفتقر إليها من حيث التوسعة ورفع الضيق المؤدي في الغالب إلى الحرج والمشقة اللاحقة بفوت المطلوب،فإذا لم تراع دخل على المكلفين على الجملة الحرج والمشقة،ولكن لا يبلغ مبلغ الفساد العادي المتوقع في المصالح العامة. و هي جارية في العبادات ،والعادات ،و المعاملات،والجنايات. ففي العبادات: شرعت الرخص المخفقة للمشقة المترتبة على السفر والمرض. وفي العادات: أبيح الصيد والتمتع بالطيبات مما هو حلال مأكلا ومشربا ،وملبسا، ومسكنا ،ومركبا ،وما أثبه ذلك.

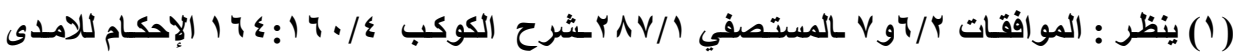

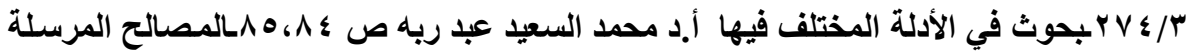

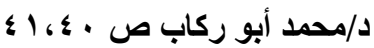


وفي المعـاملات: شرع القرض(') و المساقاة (')والسلم،(")وو إلغاء التوابع في العقد على المتبوعات كثمرة الثجر،ومال العبد.

وفي العقوبات: شرعت القسامة( ()وضرب الدية على العاقـلة وتضمين الصناع،

$$
\text { وما أشبه ذلكت. (0) }
$$

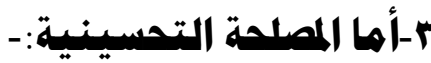

فمعناها،الأخذ بمـا يليق مـن محاسن العادات وتجنب الأحوال المدنسات التي

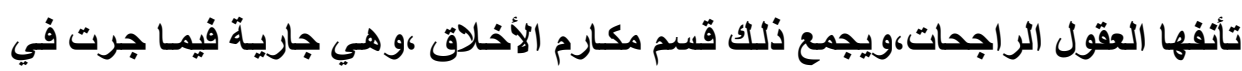
الأوليان،أي المصلحة الضرورية والحاجية.

فــي العبسادات: شـرع أنـواع الطهارات،وسـتر العورة،وأخذا الزينـة للصلاة و التقرب إلى الله تعلى بالنو افل من الطاعات كالصلاة والصيام والصدقات.

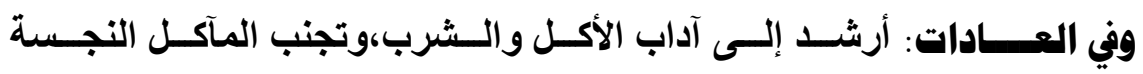
و المشروبات المستقذرة،وترك الإسراف في الطعام والثراب واللباس وغير البها.

(1) القرض :هو أن يدفع المالك الى العامل مـالا ليتجر فيهه و الريح مثترك بينهما .ينظر :مقىى

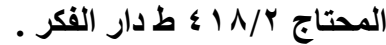

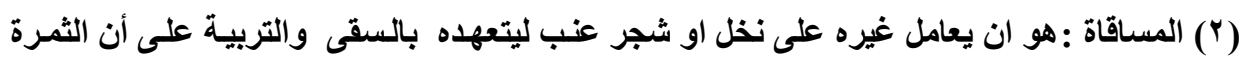

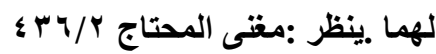

(ب) السلم :هو بيع شئ موصوف في الأنمة ،وسمى سلما لتسليم رأس المال في المجلس ،وسمى سلفا

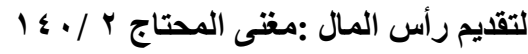

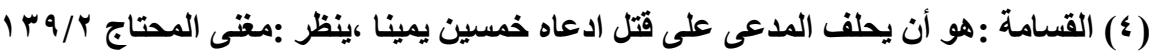

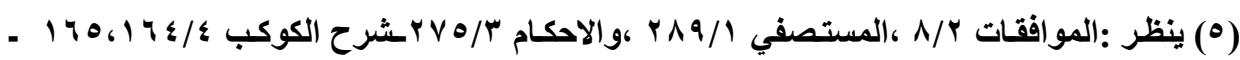

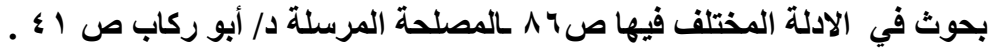


وفي المعساملات:نهى عن التعامل في كل نجس وضسار،وعن بيع فضل المباء

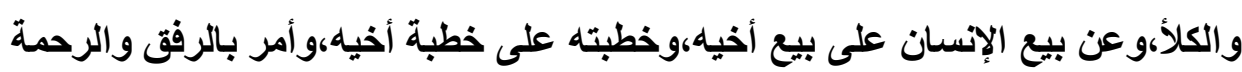
في معاشرة الزوجة و إمساكها بمعروف أو تسريحها بإحسان. وفي العقوبات:نهى عن التمثيل والغدر،وحرم قتل النساء والأطفال والرهبان في

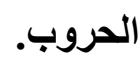

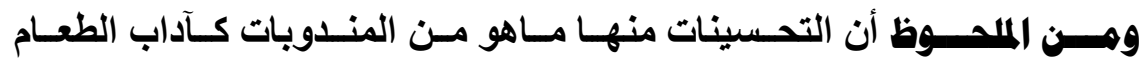
والثراب،ومنها ماهو من الفرائض المطلوبة شرعا على سبيل الحتم والإيجاب كستر

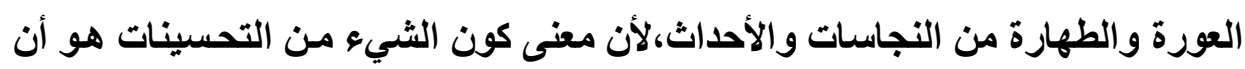

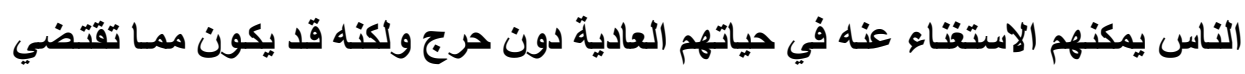

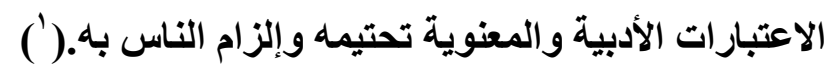

\section{الفرع الثاني \\ هتمسمات هراتب المصالح}

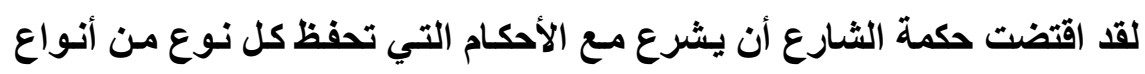
المقاصد الثلاثة السابقة أحكامـا أخرى كالتتمة لها. وكل تكملة لها من حيث هي تكملة شرط ،وهو ألا يعود اعتبارهـا علي الأصل

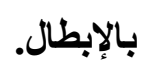




\section{وبيان ذلك: أن الصلاة مثُلا لها شروط ومكملات كالطهارة واستقبال القبلة} فإذا تعذرت هذه الثروط أو بعضها ،ويقينا مع ذلك مصرين علي توفير هذه المكملات فإن الأصل نفسه سيضيع ونبقي بغير صلاة ،فيكون اعتبار المكمل إلى أصله بالإبطال

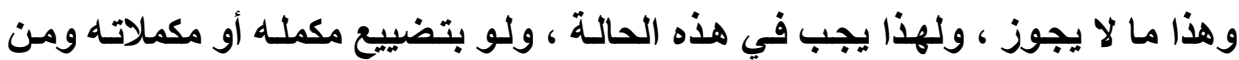
أمثلة ذلك في المعاملات البيع فمن شروطه انتفاء الغرر لكن توفيرهذا الشرط قد يكون

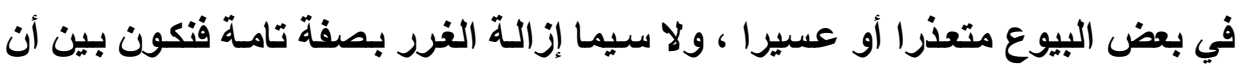
نعطل هذه البيوع التي لا بد فيها من قدر من الغرر وبين أن نمضيها مع تكلل الغرر مـا

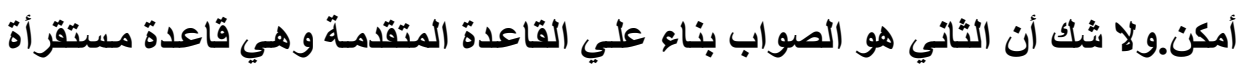

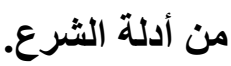
فالثارع سبحانه وتعالي جعل المصالح يكمل بعضها بعضا ويخدم بعضها بعضا وجعل الأدنى تابعا للأعلى ومتأخرا عنه في الاعتبار فلا ينبغي أن تستعمل في تعطيل

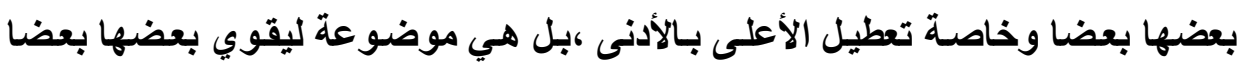
ويجلب بعضها بعضا ، ويحمي بعضها بعضا وعلي هذا الأسساس بني الثشاطبي المسألة

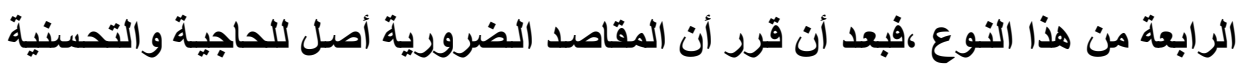
فصل ذلك في خمسة قواعد وهي: ا r ب: اختلال الضروري يلزم منه اختلال الباقين بإطلاق ץ: لا يلزم من اختلال الباقين اختلال الضروري ؛ : قد لا يلزم من اختلال التحسيني بإطلاق ،أو الحاجي بإطلاق ،اختلال الضروري

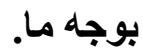


•: ينبغي المحافظة علي الحساجي والتحسيني للضروري ومرمـاه من تقرير هذه القواعد وترتيبهـا هو الوصسول إلـي النتيجـة المقررة في القاعدة الخامسة والمبنية بدورها علي القاعدة الرابعة(') وذلك أنـه لأجل حفظ الضروريات لا بد من المحافظة علي الحاجيات والتحسينات بصفة عامة لأن في إبطال الأخف جرأة علي ما هو أكد منـه ومدخل للإخـلال بـه فصار الأخف كأنهـ حمى للآكد والراتع حول الحمى يوشك أن يقع فيـه فـالمتجرئ علـي الأخف بالإبطال بـه معرض للتجرؤ علي ما سواه فإذاً قد يكون في إبطال الكمالات بإطلاق ، إبطال

$$
\text { الضروريات بوجه ما( ). }
$$

أهمية هذا التقسيم : تظهر أهيـة هذا التقسيم في الترجيح بين المصالح عند التعارض وذلك عندما تكون الواقعة الواحدة مناطاً لمصلحتين إذ يجب ترجيح إحدى المصلحتين علي الأخرى ، وقد قرر علمـاء الأصول أن المصلحة الضرورية تقدم علي المصلحة الحاجية ،والمصلحة الحاجية تقدم علي المصلحة التحسينية ،ويقدم مكمل الضروري علي الحاجي ،ومكمل الحاجي علي التحسيني(")

$$
\text { الامطاب الثاني }
$$

أقسام المصلحة من حيث العموم والخصوص أو الوضوح والخفاء.

تنقسم الملحة هن حيث العموم والفصوص إلى ثلاثة أقسام:1- مصلحة عامة

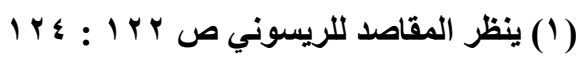

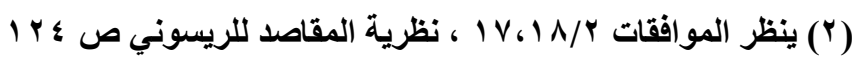

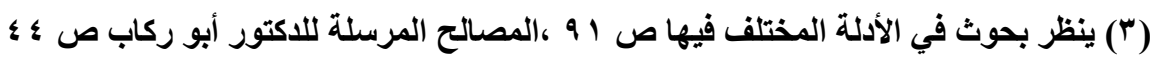




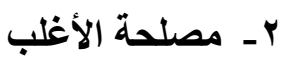 \\ ب- - مصلحة خاصة}

وهذا التقسيم للمصلحة ذهب إليه الإمام الغزالي (')في كتابهـ شفاء الغليل فقال

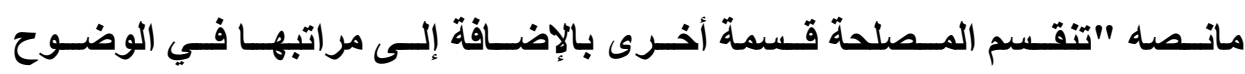

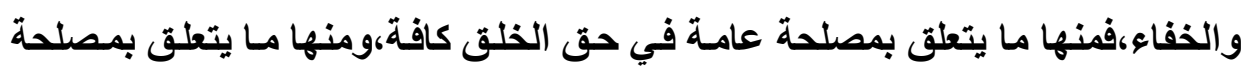

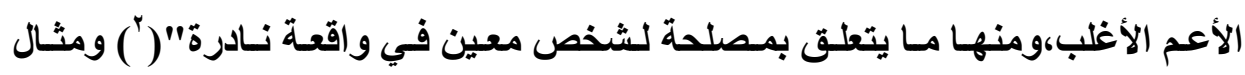

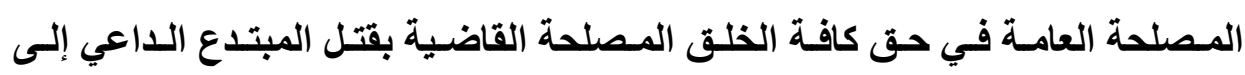
باعته،،إذا غلب على الظن ضـرره وصـار ذلك الضرر كلياً،والمصلحة بقتل الزنـديق المستتر وعدم قبول توبته بعد القدرة عليه.

ومثـال المصلحة التي تتعلق بـالأعم الأغلب ،تضمين الصناع(بّ) ، فالتضمين مصلحة لعامة أرباب السلع وليسوا هم كل الأمة ولاكافة الخلق. ومثال المصلحة الخاصة النادرة،المصلحة القاضية بفسخ نكاح زوجة المفقود، وانقضاء عدة من تباعدت حيضتها بالشهر فإن هذه مصالح نادرة تتعلق بشخص واحد

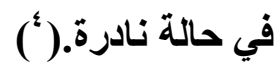

$$
\text { (1) (1) سبقت ترجمته ص في البحث (1) }
$$

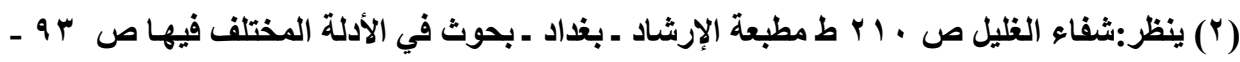

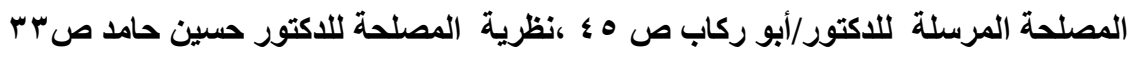

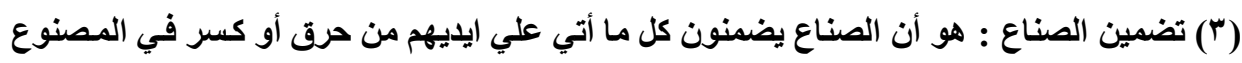

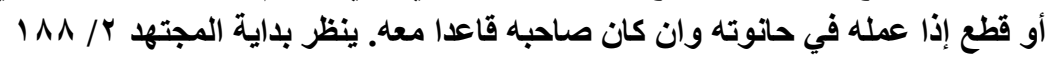




\section{أهسمية التقسيبم:-}

وتظهر أهمية هذا التقسيم عند الترجيح بين المصالح المتعارضة فعند التعارض بين المصالح فإن المصلحة العامة تقدم على مصلحة الأغلب والخاصسة،وتقدم مصلحة

$$
\text { الأغلب على المصلحة الخاصة. }
$$

وعلى هذا الأساس فقد قدموا مصلحة أرباب السلع على مصلحة بعض الصناع

إذا غلب التعدي والتقصير على مجموع الصناع كما قدموا منـع بيع الحاضر للبـادي(' (')

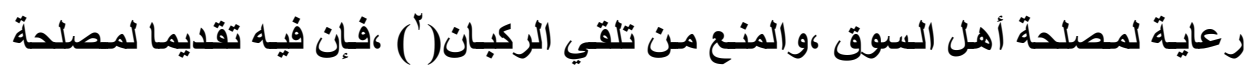
عامة هي مصلحة أهل السوق على مصلحة خاصة هي مصلحة المتلقي في أ ن يحصل على السلعة ويعيد بيعها بربح يعود عليه.(")

\section{المطلب الثالث}

أقسام المصلحة من حيث اعتبار الشارع لها أو عدم اعتباره لها.

تنقسم المصلمة هن هذا الاتجاه إلى ثلاثة أقسام :-

$$
\text { r } 1 \text { - مصالح معتبرة }
$$

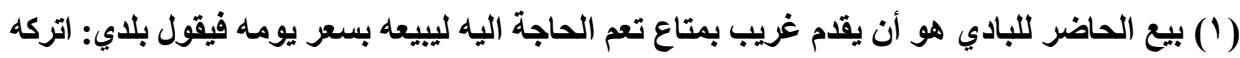

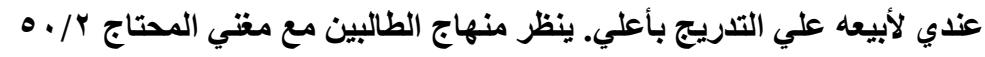

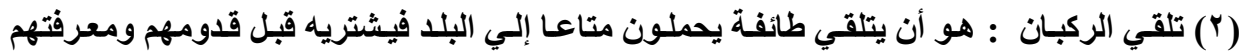

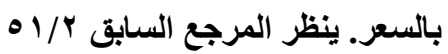

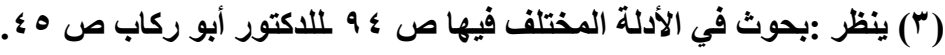


وهي التي اعتبرها الشارع بنص أو إجماع ،أو ترتيب الحكم على وفقها فى

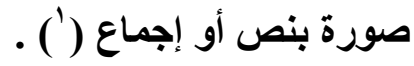

وحاصل هذه المصلحة يرجع إلى القياس،وهو اقتباس الحكم من معقول النص

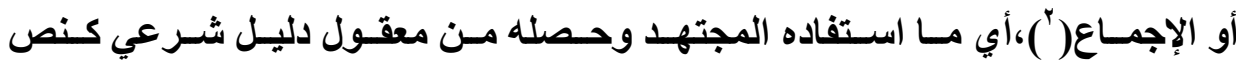

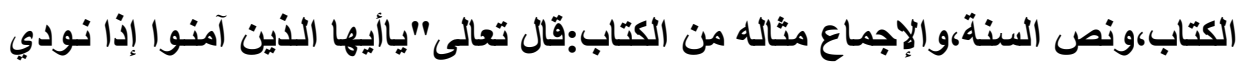
للصلاة من يوم الجمعة فاسعوا إلى ذكر الله وذروا البيع"(") فاللفظ يدل هنا على تحريم

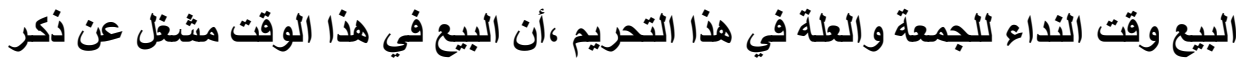
الله وعن الصلاة.فيقاس على ذلك كل مـا يشغل عن ذكر الله وعن الصلاة كالإجـارة

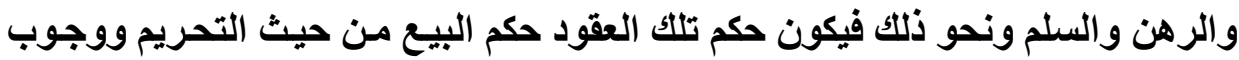
الترك.

و المصلحة المقصودة بهذا القياس تسمى المصلحة المعتبرة من الثارعومثاله

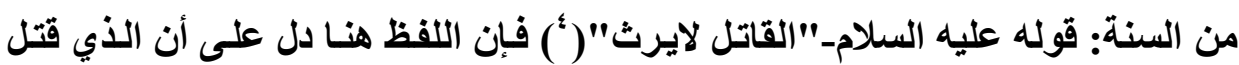

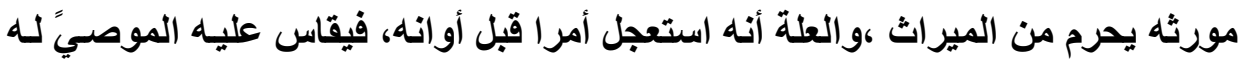

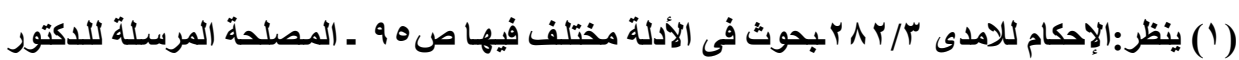

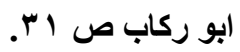

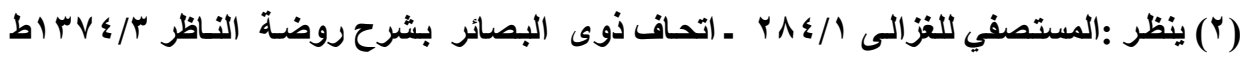

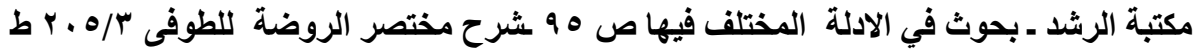

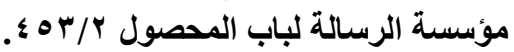

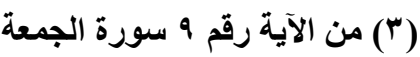

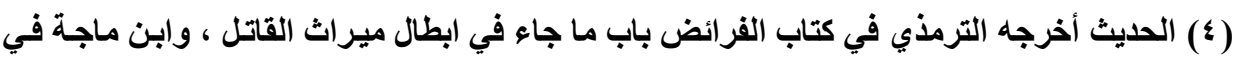

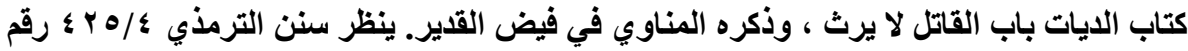

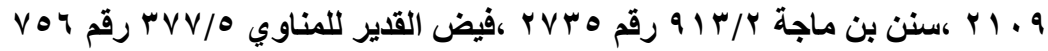


الـذي قتـل الموصسى فإنـهـ يحـرم مـن الوصـية لأنـهـ اسـتعجل أمـرا قبـل أوانـه فيعاقب بحرمانه فهنـا الجـامع واحد،صار الموصسي لله الذي قتل الموصيً كالوارث الذي قتل مورثه من غير فرق. والمصلحة المقصودة بهذا القيساس تسمى المصلحة المعتبرة من

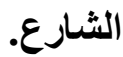
هثاله هن الإجماع: أن العلماء أجمعوا على أن القاضي يُمنع من القضاء وهو

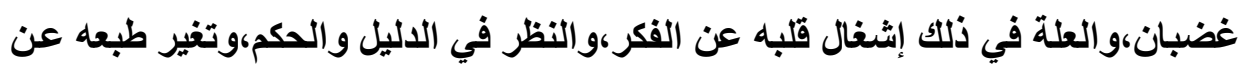
السكون والتلبث للاجتهاد.

فيقاس على ذلك كل ما يشغله عن النظر في الاليل والحكم،وكل مايغير طبعه فإن من هذا شأنه يمنع من القضاء.(') والمصلحة المقصودة بهذا القيساس تسمى المصلحة المعتبرة من الثارع وهذا النوع من المصالح حجة عند كل من يقول بحجية القياس من من من العلماء ومتفق على صحة التعليل به وبناء الأحكام عليه(').

ثانيا:المسالج اللاغاة:

وهي المصالح التي ليس لهـا شـاهد اعتبار من الشرع ،بل شـهـ الشرع بردهـا وجعلها ملغاة لا تعتبر وينبغي إن نشير هنا إلى أن الشارع الحكيم لا يلغي مصلحة من

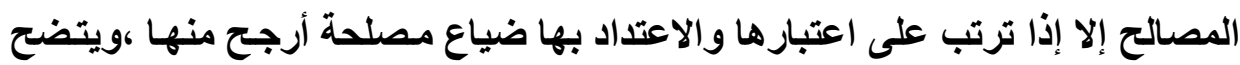
هذا من خلال عرض الأمثلة. 
ومثال ذلك: ما روي أن عبد الرحمن بن الحكم الأموي(') أحد ملوك الأندلس كـان قـ جـامع زوجته في نهـار رمضان،ثم نـلم على فعلته وأراد أن يعرف حكم الله

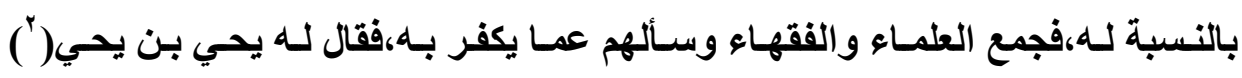

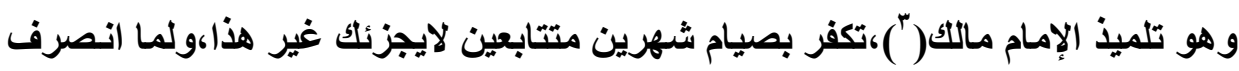
العلمـاء أنكروا على يحسي بـن يحي فتواه هذه وقـالوا لـه:القـادر على إعتـاق الرقبـة

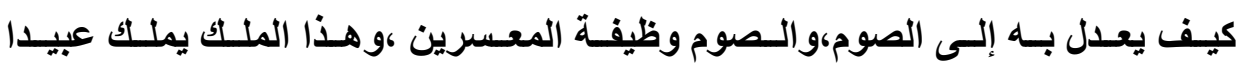
غير محصورين فأجابهم قائلا إن المقصود من الكفارة الردع والزجر،والملك لا ينزجر بغيـر الـصوم،ولو فتحنـا لـهـ بـاب التكفير بـالعتق لسهل عليـه هــا الأمـر ولكـان فيـه إغراء لله بأن يجامع كل يوم ويعتق رقبة فحملته على أصعب الأمور لئلا يعود إلى مثل

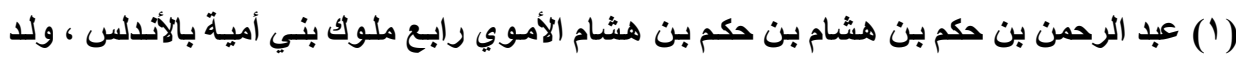

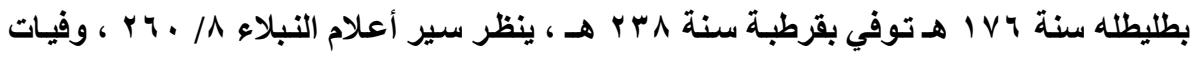

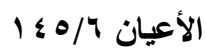

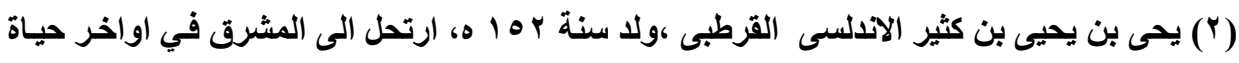

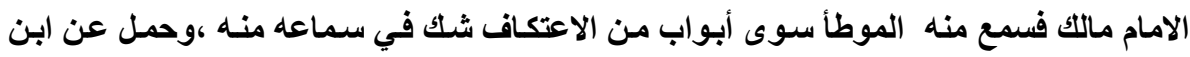

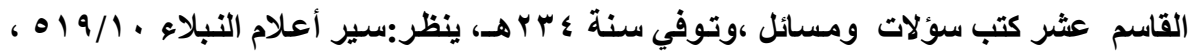

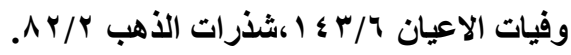

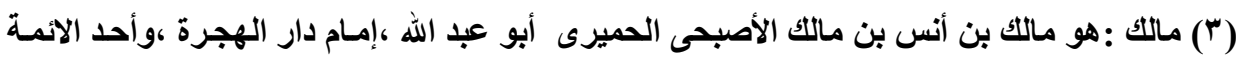

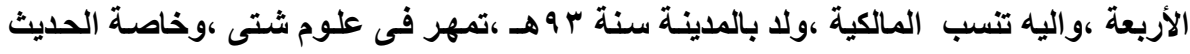

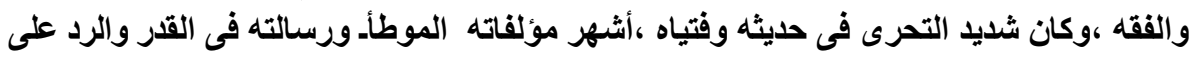

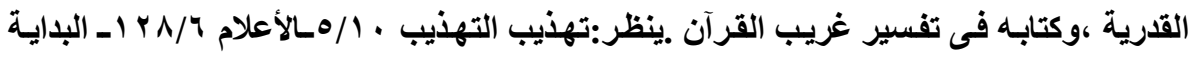

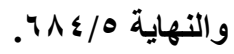

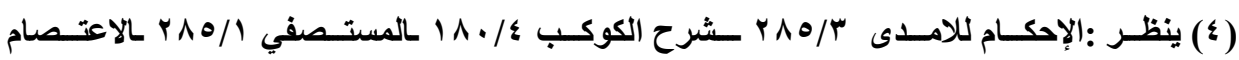

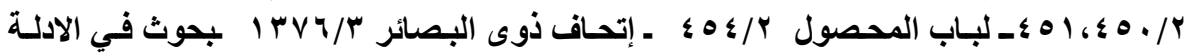

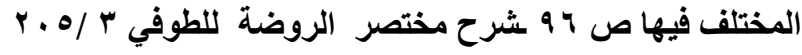


فهذا الفقيه قد بنى فتواه على مصلحة وهي أن حمل هذا الملك على مـا يعتبر زجرا لله عن العود إلى انتهاك حرمة الصوم وهي ولا شـك مصلحة لكن الشارع الحكيم لم ينظر إليها ولم يعتبرها الأعرابي حيث جاء أعرابي إلى النبي ،وقال هلكت ،ققال لـه

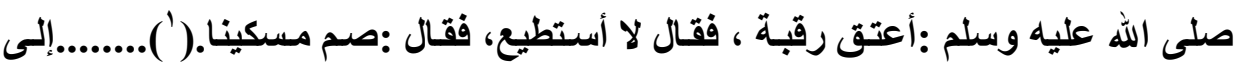
أخر الحديث.

فهنا قد قدم الشارع العتق لمصلحة العباد،ولكن ذلك الفقيه قد ترك العتق وأوجب على الملك صيام شـهرين لمصلحة قد توهمها ، ولكن هذه المصلحة المتوهمة ملفاة لأنها معارضة للنص الثرعي(r).

هثال آخر:الاستسلام للعدو أثناء المعركة ، يظهر أن فيه مصلحة وهي حفظ النفوس من القتل ،ولكن الشارع الحكيم قد ألفى هذه المصلحة ولم يعتد بها وأمر بدفع العدو ومقاتلته نظر المصلحة أرجح منها ،وهي حفظ كيـان الأمسة وكر امتها إذا ماثبت

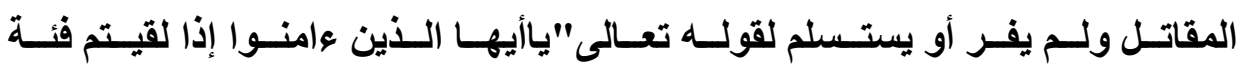
فاثبتوا"(")ويقول أيضا :" يا أيها الذين آمنوا إذا لقيتم الذين كفروازحفـا فلا تولوهم

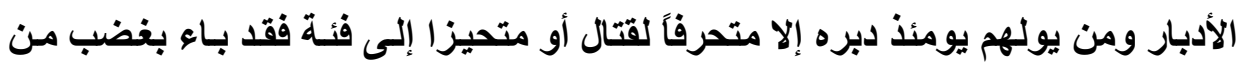

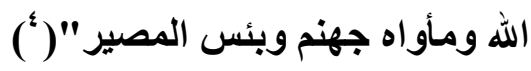

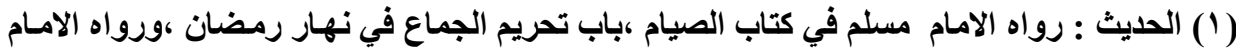

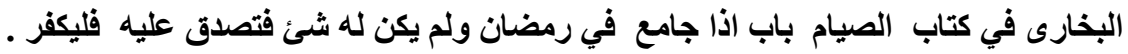

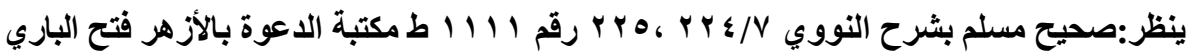

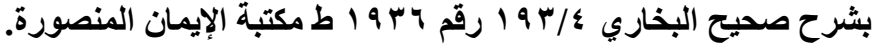

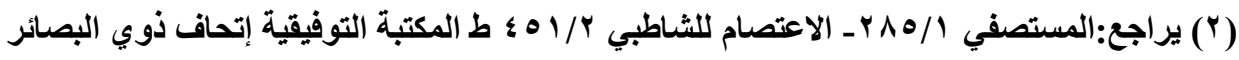
T

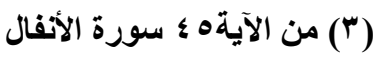

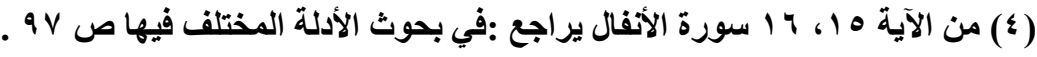


وهذا النوع من المصالح لا يصح الاحتجـاج بـه ،وهو باطل باتفاق العلمـاء ولا

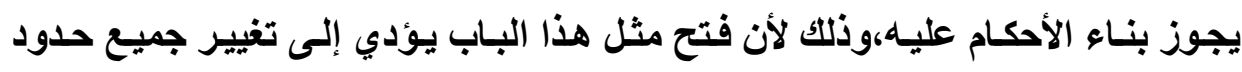

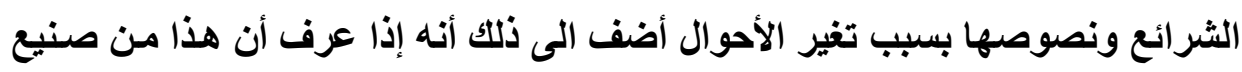
العلماء لم تحصل الثقة للملوك بفتو اهم ،ولظنوا أن كل مـايفتون بـه إنما هوتحريف من الته

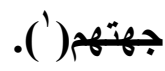

\section{ثالثا المصالح المرسلة: -}

وقد سبق الكلام عن تعريفها عند الكلام علي المناسب المرسل في المبحث

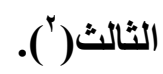

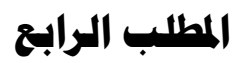

من خلال دراستتا للمصلحة و أقسامها وجدنا كثيرا من الأصوليين يطلقونها علي المناسبة ومن هنا يحسن بنا أن نتبع تقسيماتهم لها باختصار وهي كما يلي:

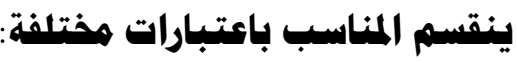

أولاً : باعتبار ذات المناسبة

ثانياً: باعتبار المقصود الحاصل من ترتب الحكم عليه ، ثالثًا: باعتبار إفضائه إلي المقصود ،

رابعاً: باعتبار اعتبار الثارع إياه وعدم اعتباره.

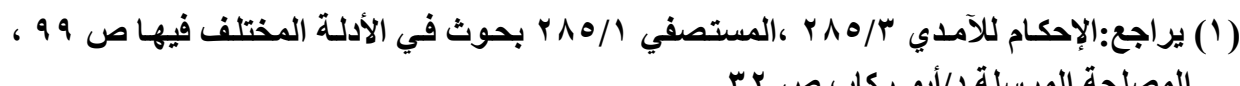

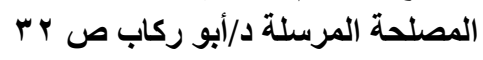

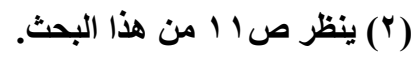

ror مجلتّ البحوث القانونيت والإقتصاديت 


\section{التقسيم الأول للمناسب وهو باعتبار ذات المناسبة:}

فهي تنقسم بهذا الاعتبار إلي قسمين:

1- حقيقي : وهو الذي لا تزول مناسبته بالتأمل فيه وأمثلته كثيرة سيأتي الكلام

$$
\text { عنها في التقسيم الآتي : }
$$

r- إقناعي : وهو الذي تظن مناسبته في بادئ الرأي ،واذا بحث عنه وضح أنه غير

مناسب.

مثال الإقناعي : تعليل الثافعية تحريم بيع الخمر والميتة والعذرة بنجاستها ،

$$
\text { وقياس الكلب والسرجين عليه. }
$$

ووجه المناسبة : أن كونه نجسا يناسب إذلاله ، ومقابلته بالمال في البيع يناسب

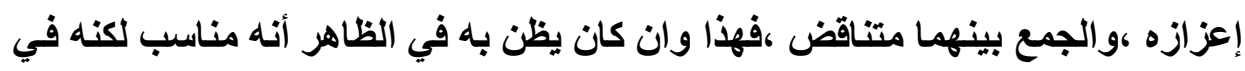
الحقيقة ليس كذلك لأن كونه نجسا معناه أنه لا يجوز الصلاة معه ،ولا مناسبة البتّة بين المنع من اصطحابه في الصلاة وبين المنع من بيعه(').

التقسيم الثاني المناسب باعتبار الاقصود الحاصل هن ترتب الحكم عليه:

$$
\text { ينقسم المناسب الحقيقي باعتبار المقصود إلي }
$$




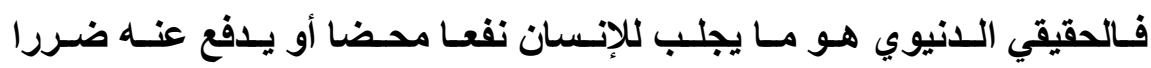

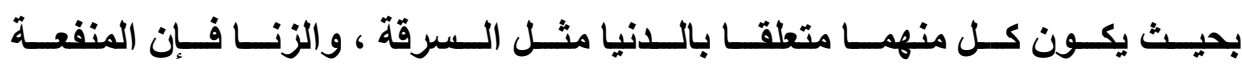
المترتبـة علـي شـرع الحكم عندهما وهـي حفظ النفس وحفظ المـال متعلقـة بالحيـاة الدنيا.

\section{والدنيوي ينقسم إلي ثلاثة أقسام:}

$$
\text { r r- ا- - مصلحري. }
$$

وذلك لأن المقاصد التي تفضل الله تعالي فشرع الأحكام لأجلها وهي جلب المنـافع للعباد ، ودفع المفاسد عنهم إما أن تكون حاصلة في الانيا أو حاصلة في الأخرة ، فبان كانت في الانيا فالانيوي وان كانت في الأخرة فالأخروي.

ثم إن الانيوي إما أن تكون الحاجة إليه بالغة حد الضرورة فهو الضروري وإمـا أن يكون محتاجا إليه لكن الحاجة إليه لم تصل إلي حد الضرورة فهو المصلحي ويعبر إندان عنها بالحساجي ،و إمـا أن لا يكون محتاجـا إليهه بـل يكون مستحسنا في العـادات فهو التحسيني.

والضروري إمـا أن يكون ضروريا في أصله أو مكملا للضروري فـالأول منحصر في المقاصد الخمسة التي هي حفظ الدين ،والنفس ،والعقل ،والنسب ،والمال('). 
فإن حفظ هذه الأمور الخمسة من الضروريات وهي أعلي مراتب المناسبات ،

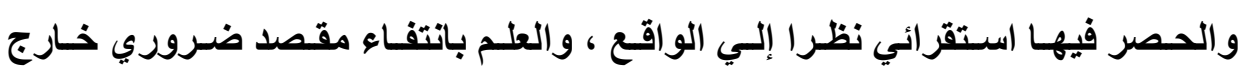

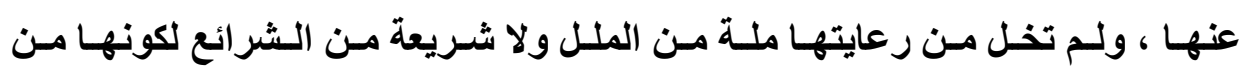
المهمـات التي بها يرتبط نظام العـالم ، ولا يبقي نوع الإنسان مستقيم الأحوال بدون

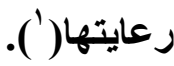

والهميقي الأخروي : هو ما يجلب للإنسان نفعا أو يدفع عنه ضررا بحيث يكون

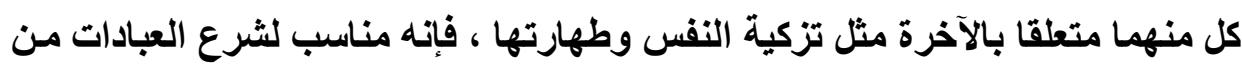
صوم وحج وصلاة ، والعبادات منافعها أخروية وهي الثواب ومنع العقاب. جاء في نبراس العقول : "وأمسا المقصود الذى يحصل في الآخرة فلا يخرج عن جلب الثواب ودفع العقاب.

فالأول: كالمقصود من إيجاب الطاعات وأفعال العبادات ، فإنها تفضي إلي نيل

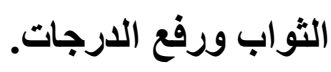
والثاني : كالمقصود من تحريم أفعال المعاصي وشرع الزواجر عليها، فإن ذلك يفضي إلي دفع العقاب المرتب علي تلك الأفعال( ). وقال الإمهام الرازي(") : "وأما الأي يكون مناسبا لمصلحة تتعلقبالآخرة فهي

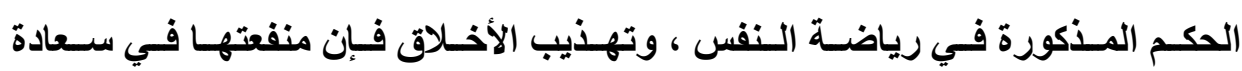

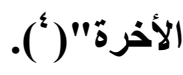

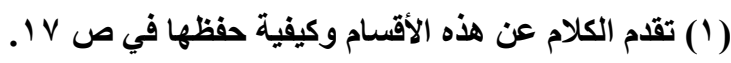

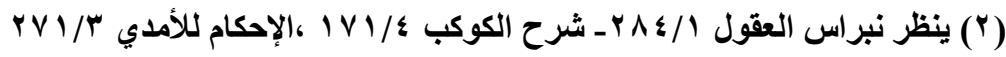

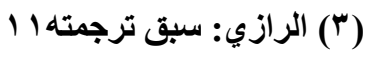

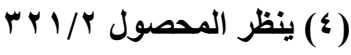




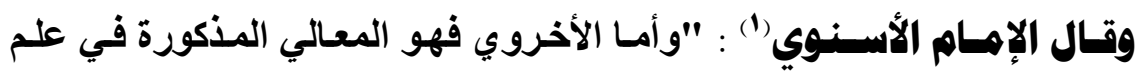

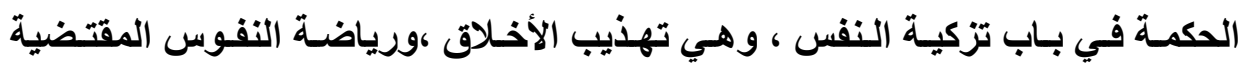

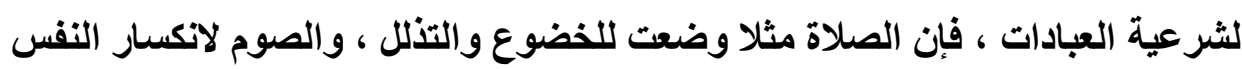

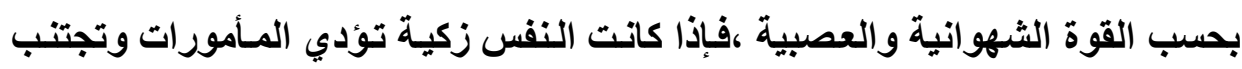

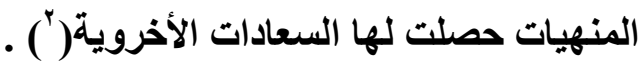

\section{بقي قسم ثالث ،وهو ها يتعلق بهصالح الدارين:}

و المراد بمصالح الدارين ، الدنيوي ، والأخروي وذلك كإيجاب الكفارات إذ يحصل

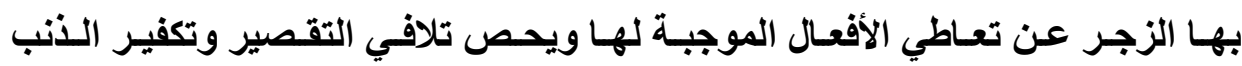

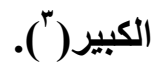

وقد جاء في شرح الكوكب: "وقد يتعلق المناسب بهما أي باللنيوي والأخروي

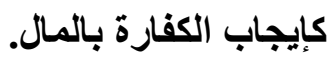

فتعلقه الدنيوي: ما يعود علي الفقراء من المصلحة باتتفاعهم بالمال.

$$
\text { وتعلقه الأخروي: ما يحصل للمكفر من الثواب("). }
$$

(1) هو جمال الدين بن عبد الرحيم بن الحسن بن عمر بن علي بن إبراهيم القرشي الأمسوي الإسنوي

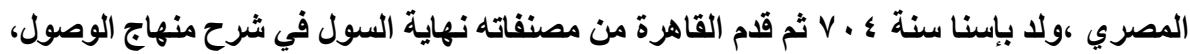

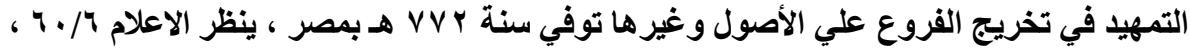

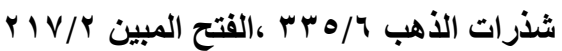

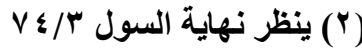

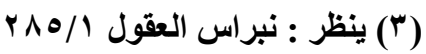

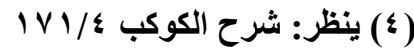


التقسيم الثالث للمناسب باعتبار إفضائه إلي المقصود وعدمه. ينقسم بهذا الاعتبار إلي قسمين أحدها باعتبار إفضائه إلي المقصود. اعلم أن شرع الحكم إما أن يكون مفضيا إلي تحصيل أصل المقصود ابتداء ، أو

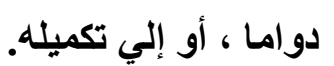

فـالأول: وهو المفضي إلـي أصل المقصود في الابتداء مثثل القضاء بصحة التصرف الصادر من الأهل في المحل تحصيلا لأصل المقصود المتعلق بـه من الملك والمنفعة كما في البيع والإجارة ونحوهما. والثاني: وهو المفضي إلي دوام المقصود مثل القضاء بتحريم القتل وإيجاب القصاص علي مـن قتل عمدا عدوانـا لإفضائه إلـي دوام المـصلحة المتعلقة بـالنفس الإنسانية المعصومة .

والثالث: وهو المفضي إلي تكميل المقصود مثل الحكم باشتراط الثهادة ومهر المثل في النكـاح فإنـه مكمل لمصلحة النكاح وليس محصلا لأصلها لحصولها بنفس إنس التصرف وصحته('). (') (')

\section{وحصول المقصود هن شرع الحكم خسسة أقسام:}

1 ـ أن يحصل المقصود منه يقينا كالبيع ،فإنه إن كان صحيحا حصل منـه الملك الذي

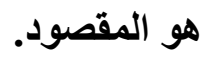
r- أن يحصل المقصود منه ظنا كالقصاص للإنزجار ، فإن حصول الإنزجار عن القتل ليس قطعيا ،بلليل وجود الاقدام مع علمهم بأن القصاص مشروع .

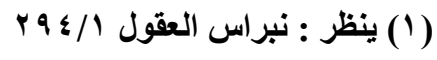




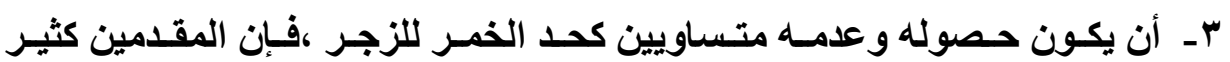
والمجتنبين كثير فتساوي المقصود وعدمه فيه.

ع - أن يكون نفي الحصول أرجح من الحصول بأن يكون عدم حصول المقصود أرجح من حصوله كنكاح الأيسة من الحيض للتوالد ، لأنه مع امكانـه عقلا ،بعيد عـادة ، ولأن عدد من لا تنسل منهن أكثر من عدد من تنسل . هـ - أن يكون المقصود فائتا بالكلية ،مثاله جعل النكاح مظنة حصول النطفة في الرحم فترتب عليه إلحاق الولا بـالاب ،فإذا تزوج مشرقي بمغربي وقد علم قطعا عدم

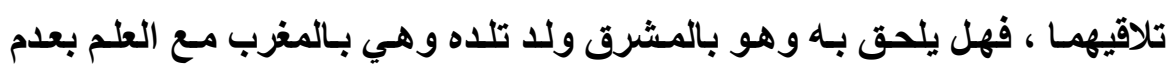
حصول النطفة في رحمها قطعا('). وثانيهـها : باعتبار المقصود وعدمه. ينقسم بهذا الاعتبار إلي ضربين : الضرب الأول: ضروري. الضرب الثاني: غير ضروري. الضرب الأول :ضروري والضروري ينقسم إلي قسمين: الأول ضروري في أصله. والثاني مكمل للضروري.

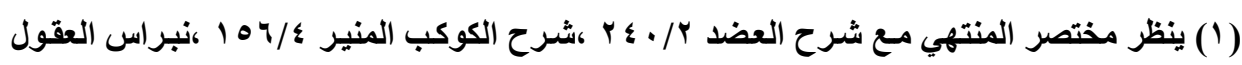

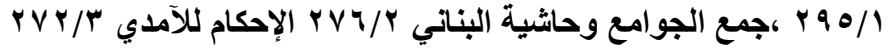




\section{القسم الأول: الضروري في أصله.}

فالـضروري في أصـله هـو أعلـي المراتب في إفـادة ظن الاعتبـار كالخمسة الضرورية التي روعيت في كل ملـة وهي حفظ الدين ،والنفس ، والعقل ،والنسل ، والمال.

فالدين بقتل الكفـار ، والنفس بالقصاص ، والعقل بحد المسكر ،والنسل. بحد

$$
\text { الزنا ،والمال بحد السارق،والمحارب أي قاطع الطريق. }
$$

وذلك كد قليل المسكر وهو لا يزيل العقل ،وحفظ العقل حاصل بتحريم السكر ،

فإنما حرم القليل للتميم والتكميل ، ،لأن قليله يدعو الي كثيره بمـا يورث النفس من الطرب المطلوب زيادته بزيادة سببه الي أن يسكر ،ومن حام حول الحمي أوشك أن يقع

\section{الضرب الثاني غير الضروري.}

وينقسم إلي حاجي وغير حاجي.

القسم الأول: الحاجي

$$
\text { وهو ينقسم أيضا إلي قسمين: }
$$

أحدههما: حاجي في نفسه ومثاله البيع ،والإجارة ،والقراض ،والمساقاه، فكل

$$
\text { واحد من هذه العقود لو لم يشرع لأدي إلي فوات شئ من الضروريات الخمس. }
$$

وثانيهـهـا: مكمل للحساجي ، ومثالـهـ ، وجوب رعايـة الكفالـة ومهر المثل في الولي إذا زوج الصغيرة فبإن أصل المقصود من شرع النكاح وان كـان حاصـلا بـدونها لكنه أشد إفضاء إلي دوام النكاح وهو من مكملات مقصود النكاح. 


\section{القسم الثاني غير الحاجي :}

وهو ما لا حاجـة إليه لكن فيه تحسين وتزين وسلوك منهج أحسن من منهج

كسلب العبد أهلية الثهادة وإن كان ذا دين وعدالة يظلبان ظن صدقه ولو جعل لـه أهلية الثهادة لحصل مصلحة مثل ما يحصل في الحر ولم تكن لله مفسدة أصلا لكنه سلب ذلك لنقصه عن المناصب الشريفة ليكون الجري علي ما ألف من محاسن العادات أن يعتبر في المناصب المناسبة ، فإن السيد إذا كان له عبد ذو فضائل وآخر دونه فيها ،استحسن عرفا أن يفوض العمل إليهما بحسب فضيلتهما ،فيجعل الأفضل للأفضل ،وان كان كل

منهما يمكنه القيام بما يقوم به الآخر(').

التقسيم الرابع للمناسب باعتبار اعتبار الشارع إياه وعدم اعتباره.

ينقسم بهذا الاعتبار إلي أربعة أقسام:

$$
\text { ז - ז- مؤثر. }
$$

القسم الأول المؤثر:

إن اعتبر مـن قبل الشرع بنص كتعليل الحدث بمس الذكر أو اعتبر بإجمـاع كتعليل ولاية المال بالصغر. 
فـالأول: اعتبر عينه في عين الحكم وهو الحدث لحديث " من مس ذكره

وأها الثـاني: فإنه اعتبر عين الصغر في عين الولاية بالإجماع وسمي هذا القسم مؤثرا لحصول التأثير فيه عينا وجنسا فظهر تأثيره في الحكم.

القسم الثاني الملائم إن اعتبر بترتب الحكم مع الوصف فقط إن ثبت بنص أو

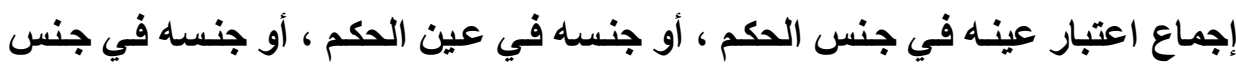

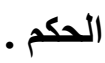

\section{وسمي ملائمًا لكونه هوافقا لما اعتبر الشارع وهو ثلاثة أنواع :}

مثال ما اعتبر الثارع عين الوصف في جنس الحكم ،امتزاج النسبين في الأخ

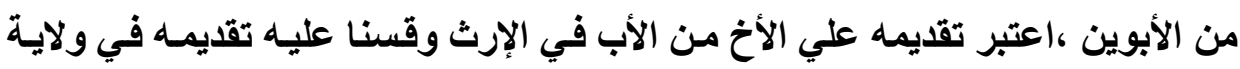

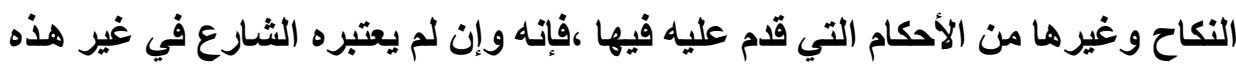

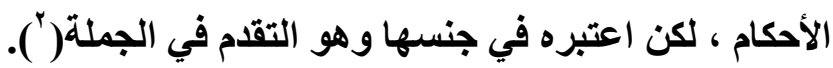
ومثنال مـا اعتبر فيسه جنس الوصف في عين الحكم المشقة المشتركة بين

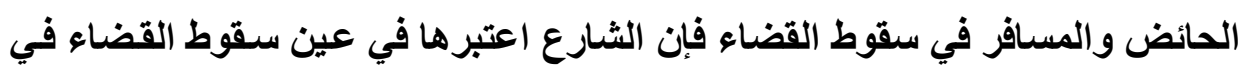
الركتين الرباعية ،فسقط بها القضاء في صلاة الحائض قياسا. و إنما جعل الوصف هنا جنسا والإسقاط نوعا ، لأن مشقة السفر نوع مخالف لمثقة الحيض ،وأما السقوط فأمر واحل وإن اختلفت محاله.

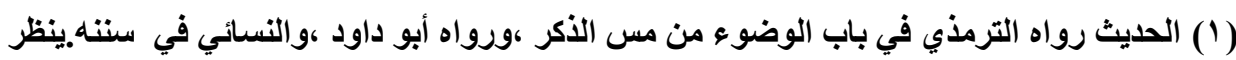

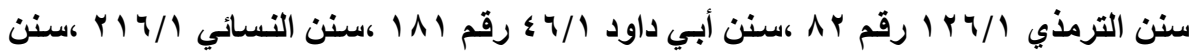


ومثال ما اعتبر جنس الوصف في جنس الحكم: مـا روي عن علي رضي الله

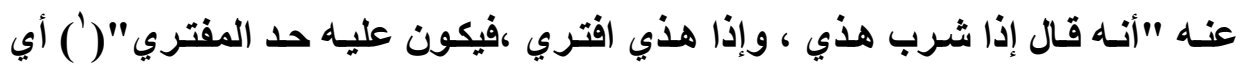

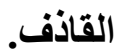

ووافقه الصحابة عليه ،فأوجبوا حد القذف علي الشارب ،لا لكونـه شرب بل بل بأل لكون الثرب مظذة القذف فأقاموه مقام القذف قياسا علي إقامة الخلوة بالأجنبية مقام

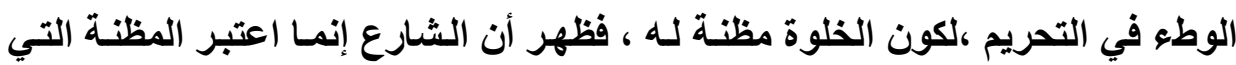

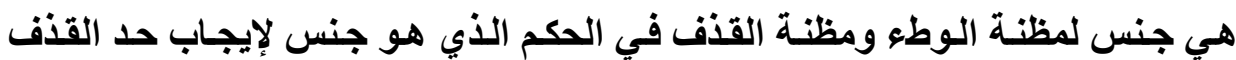

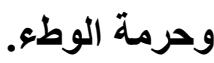

القسم الثالث الغريب: وهو إن لم يعتبر ترتب الحكم علي الوصف بنص أو إجماع فيسمي غريبا.

هثال ذلك التعليل بالإسكار في قياس النبيذ علي الخمر بتقدير عدم نصبعلية

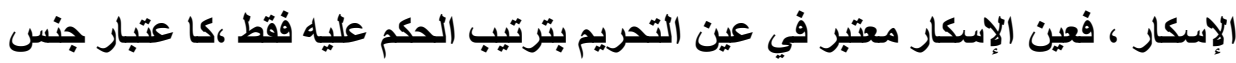

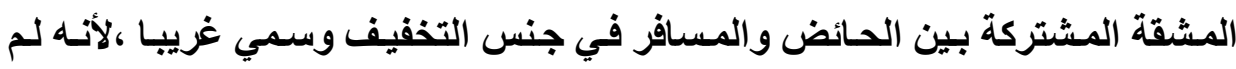
يثهد له غير أصله بالاعتبار كالطعم في الربا فإن نوع الطعم مؤثر في حرمـة الربـا وليس جنسه مؤثرا في جنسه( (). القسم الرابع: المرسل ،وهو مـا لم يعتبر لا بنص ولا إجماع ولا بترتيب الحكم

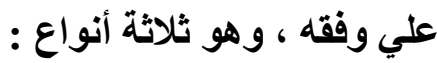
(1) رواه أبو داود في كتاب الحدود باب إذا تتابع في شرب الخمر ، وأخرجه عبد الرازق في مصنفه

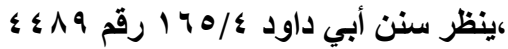

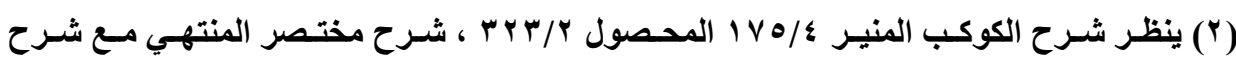

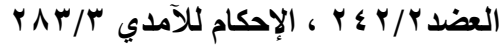




$$
\text { r- } 1 \text { - مرسل ملائم }
$$

r- مرسل ثبت إلغاؤه لأن الوصف المناسب إما أن يعلم أن الثارع اعتبره ، أو يعلم

$$
\text { أنه ألغاه ، أو لا يعلم أنه اعتبره ولا ألغاه('). }
$$

فالمرسل الملائم: هو مـا اعتبر الشارع جنسه البعيد في جنس الحكم مثالهه: تعليل تحريم قليل الخمر بأنها يـاعوا إلـي كثيرهـا فجنسه البعيد معتبر في جنس الحكم كتحريم الخلوة بتحريم الزنا.

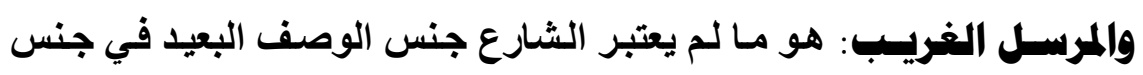
الحكم. التعليل بالفعل المحرم لغرض فاسد في قياس بات الطلاق في مرضـه علـي القاتل

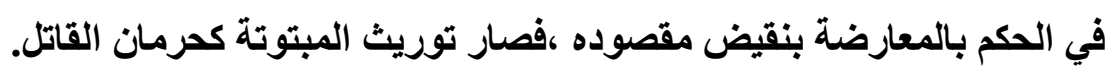
وإنما كان غريبا مرسلا ، لأنه لم يعتبر الشارع عين الفعل المحرم لغرض فاسد

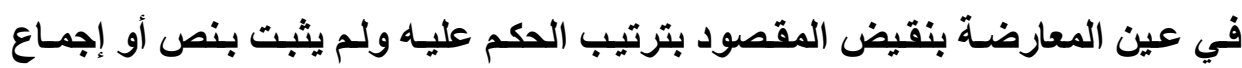
اعتبار عينه في جنس المعارضـة بنقيض المقصود ، ولا جنسه في عينها ،ولا جنسه

$$
\text { في جنسها. }
$$

والمرسـل الذي ثبـت إلغـاؤه هـو مـا علـم مـن الشرع إلغـاؤه مـع أنـه مستحيل المناسبة مثاله كإيجاب صوم شهرين ابتداء في الظهار ،أو الوطء في رمضان علي من

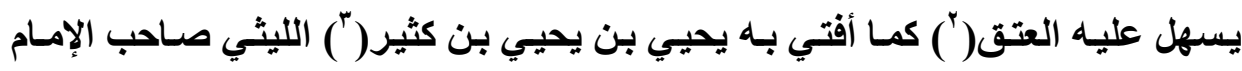
مالك(") إمام أهل الأندلس.

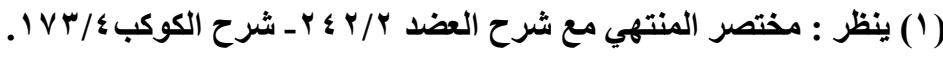

$$
\begin{aligned}
& \text { (Y) (Y) ينظر المراجع السابقة }
\end{aligned}
$$

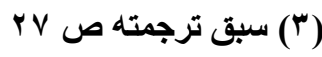

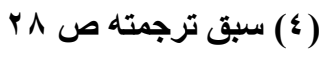




\section{الفصل الثاني \\ حبية المسالح المرسلة}

وفيه هبجثان:

المبحث الأول: مذاهب العلماء في الاحتجاج بالمصالح المرسلة .

المبحث الثـاني: أدلة المذاهب على الاحتجاج بالمصالح المرسلة،وبيان المذهب

الراجح.

\section{المبحث الأول \\ هذاهب العلمهاء في الاحتجاج بالمالح المرسلة}

اختلف الأصوليون في الاحتجاج بالمصالح المرسلة على مذاهب وهي:

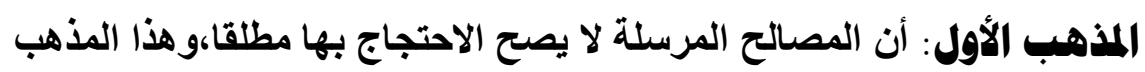

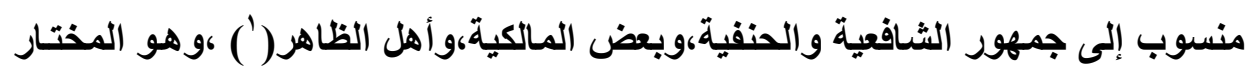

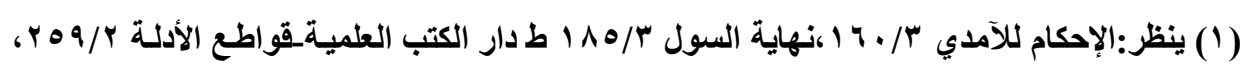

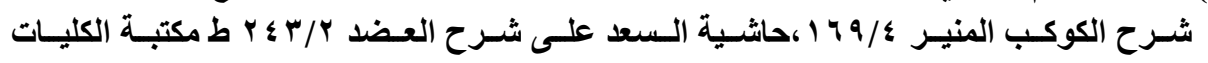

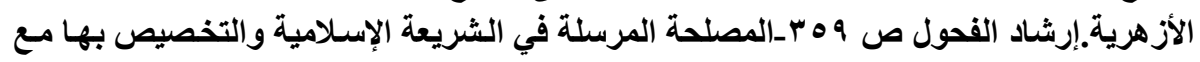

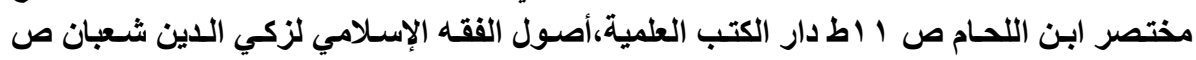

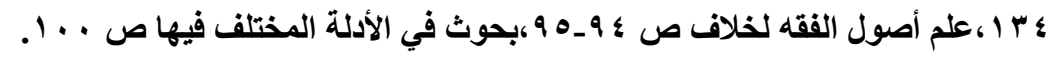

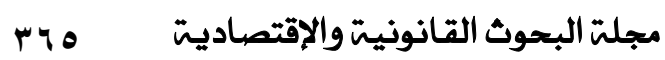


عند ابن الحاجب(')،واوالحق عند الآمدي('). فقد صرح بذلك ابن الحاجب في مختصر المنتهى حيث قـال مانصه"وإن كان

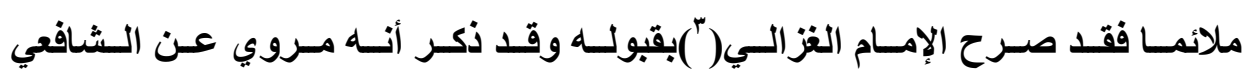

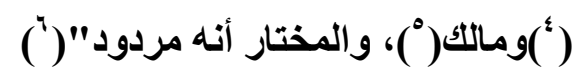

وقال الآهدي: "وقد اتفق الفقهاء من الشافعية والحنفية وغيرهم على امتناع

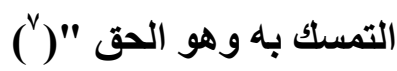

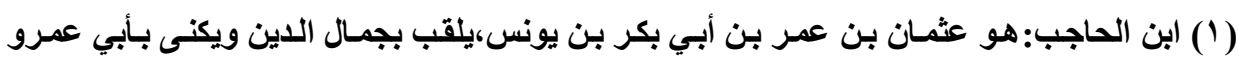

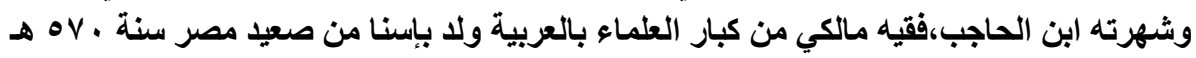

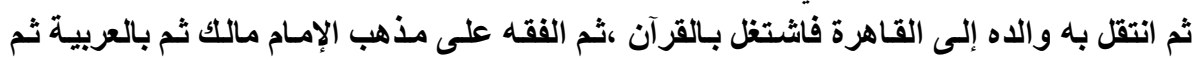

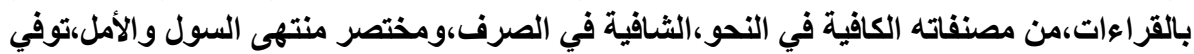

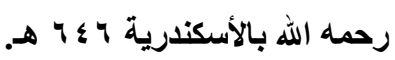

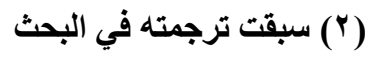

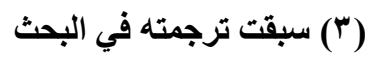

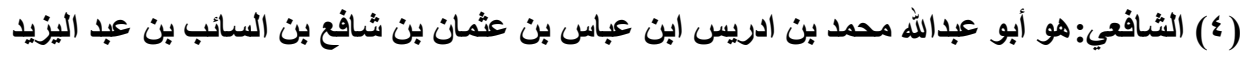

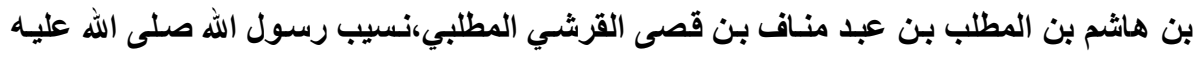

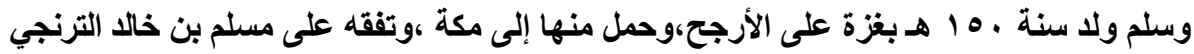

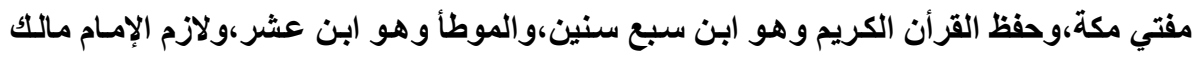

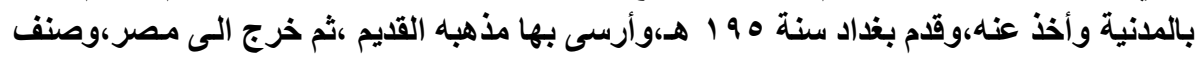

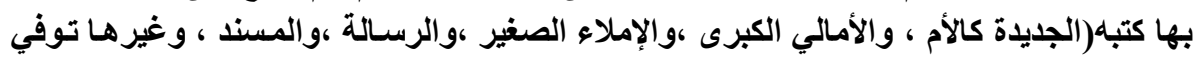

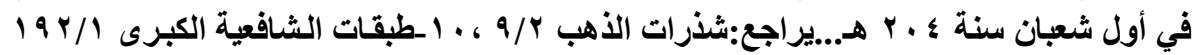

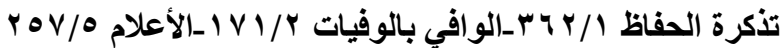




\section{المذهب الثـاني:أن المصالح المرسسلة يصح الاحتجساج بهـا إذا تـوافرت فيهـا}

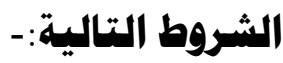

1- أن تكون من المصالح المحققة غير المتوهمة ،ومعنى ذلك أن يتحقى من أن العمل

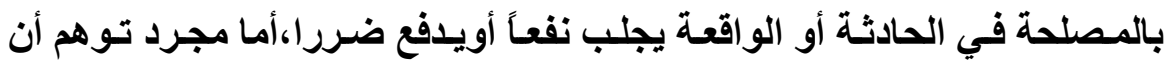

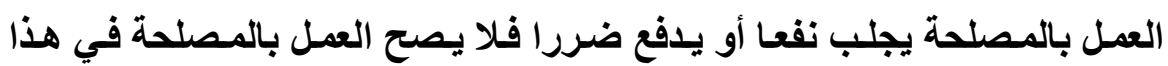

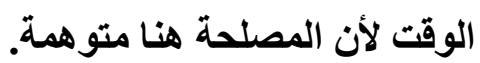

r- أن تكون المصلدة من المصالح التي لمُ يقم دليل شرعي يدل على إلغائها،أمـا إذا

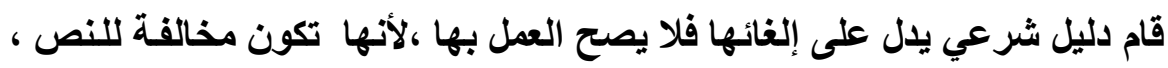

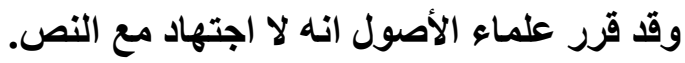
r- أن تكون المصلحة من المصالح العامة ،وتكون المصلحة عامة إذا كان بناء الحكم

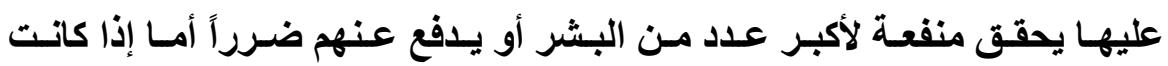

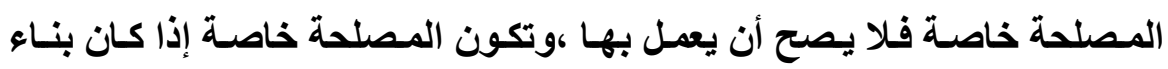
الحكم عليها يحقق منفعة لفرد أو طائفة معينة من الناس. ؛ - أن تكون المصلحة معقولة في ذاتها جرت على الأوصـاف المناسبة المعقولة التي

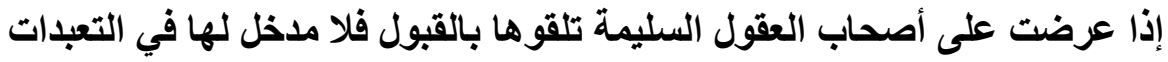
ولا ماجرى مجراها من الأمور الثرعية لأن التعبدات لايغفل معناها على التفصيل

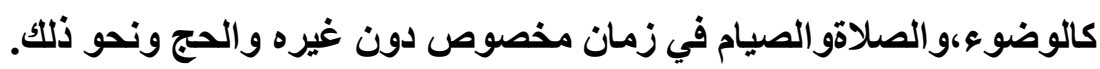
هـ أن تكون في الأخذ بها رفع حرج لازم بحيث لو لم يؤخذ بالمصلحة المعقولة في

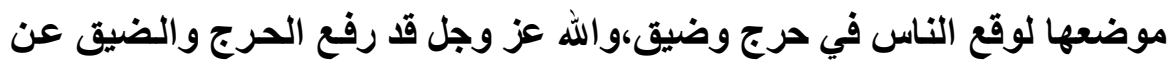
المسلمين قال تعالى"وما جعل عليكم في الدين من حرج" (') 
وهذا المذهب بهذه الشروط منسوب للأمام مالك،،قال ابن الحاجب،وقد نقل أيضا

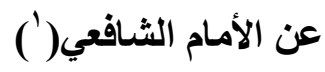

المذهب الثالث:أن الصالح المرسلة يصح الاحتجاج بها إذا توافرت فيها شروط ثلاثة وهي:

ا - أن تكون المصلحة ضرورية لا حاجية

r- - أن تكون قطعية لا ظنية

ب- أن تكون كلية لاجزئية

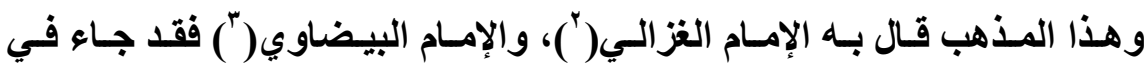

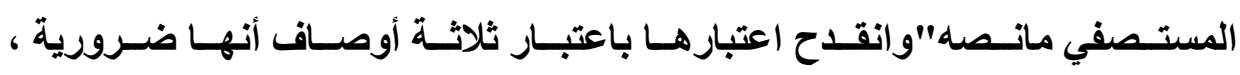

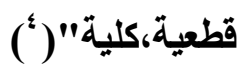

وجـاء فـي المنهـاج مانـصه:"الخـامس:المناسـب المرسـل،إن كانـت المـصلحة

ضرورية قطعية كلية كتترس الكفار الصائلين بأسـارى المسلمين اعتبر وإلا فلا،وأمسا مالك فقد اعتبره مطلقا"( ).

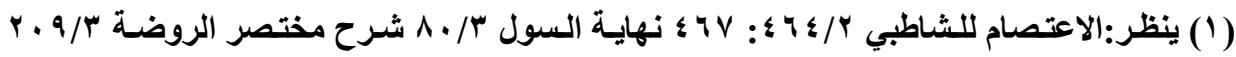

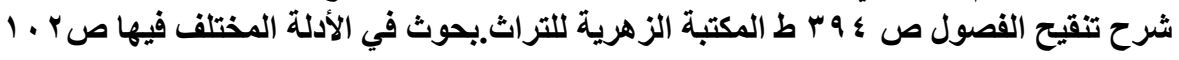

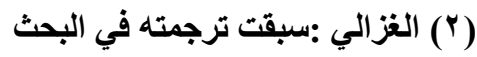

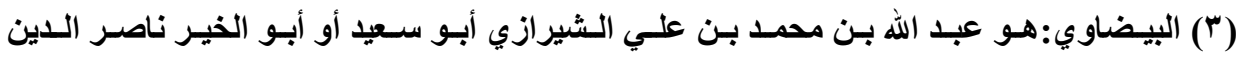

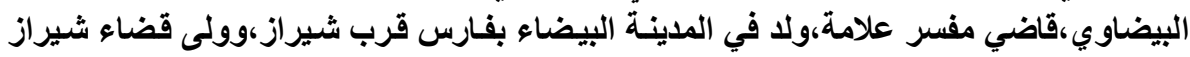

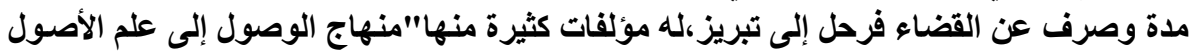

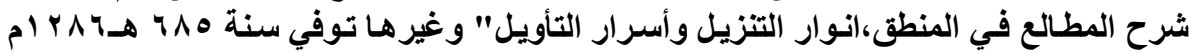

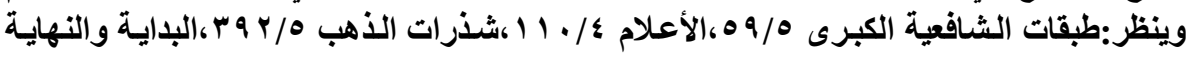

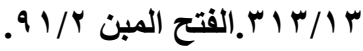

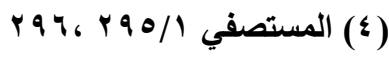

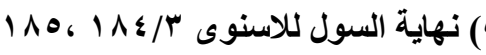


ومعنى كون المصلحة ضرورية أنها تحفظ ضرورة من الضرورات الخمس وهي

$$
\text { الدين،والنفس،و العقل،و النسل،والمال. }
$$

ومعنى كونها كلية ،أنها توجب نفعا عأمسا للمسلمين ولا تختص ببعض الأفراد

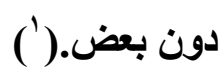

ومثلوا لذلك بمسألة الترس: وهي ما إذا هاجمنا الكفار مستخدمين في هجومهم

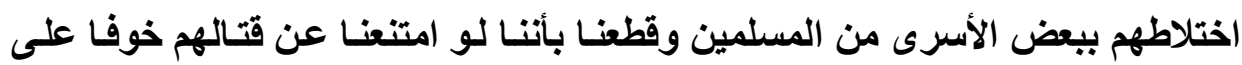
حياة هؤلاء الأسرى لهزمنا الكفار واستولوا على ديارنا ،وقتلوا المسلمين جميعا حتى هؤلاء الأسرى،ولو قاتلتناهم ورميناهم لقتلنا أسيرا مسلما من غير ذنب. فإن قتل الأسير المسلم في هذه الحالة يعتبر مصلحة مرسـلة لأنهـ لم يعهد في الشرع جواز قتل مسلم بلا ذنب كما لم يقم دليل يلل على عدم جواز قتله عند اشتماله على مصلحة عامة للمسلمين.فهي مصلحة ضرورية لأنه يترتب على قتله حفظ حياة

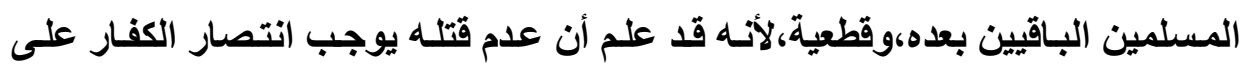
المسلمين،وكلية ،من حيث إنها تتعلق بحياة جميع المسلمين('). فهذه المسألة وأمثالهـا إذا مـا تـوفرت فيهـا الشروط الثلاثـة السـابقة يـصح اعتبارها،بمغى أنه يجوز أن يؤدي اجتهاد مجتهـ إلى أن يقول:هذا الأسير مقتول بكل

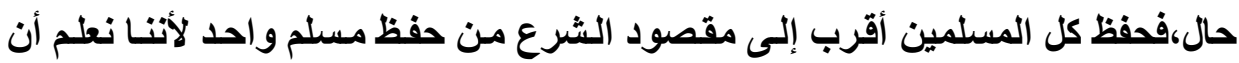
مقصود الشارع تقليل القتل ،بل حسم سبيله عند الإمكان ،فان لم نقدر على الحسم قدرنا

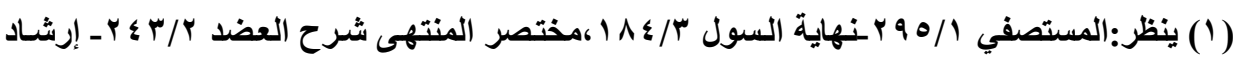

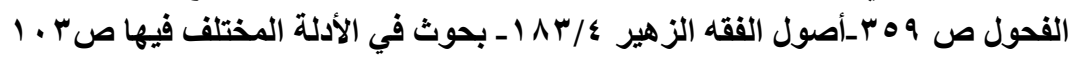

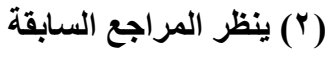


على التقليل،وكان هذا التفاتا إلى مصلحة علم بالضرورة كونها مقصود الثرع لا بدليل واحد وأصل معين بل بأدلة خارجة عن الحصر.

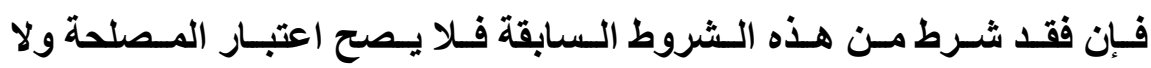

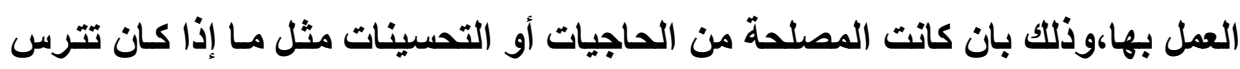

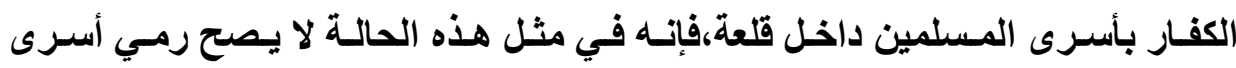

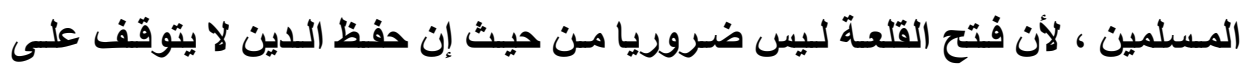

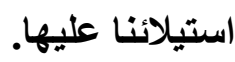

وكذلك إذا كانت المصلحة غير قطعية،كما إذا لم نقطع بتسلط الكفار وعزمهم على المئه

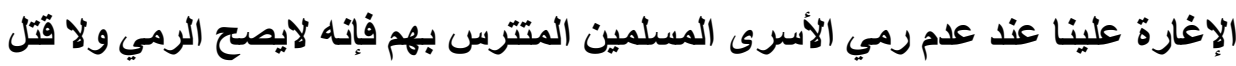
المسلم لكون المصلحة غير مقطوع بها. وأيضا: إذا كانت المصلحة غير كلية بـأن كانت جزئيسة تتعلق ببعض الأفراد

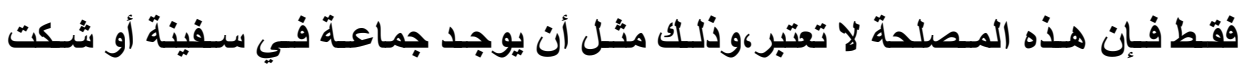

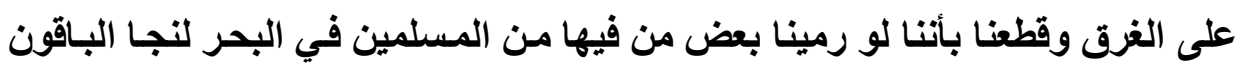

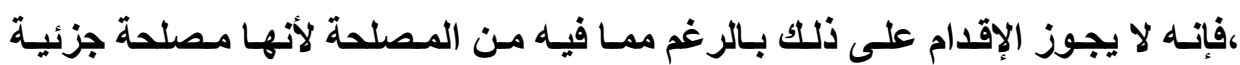

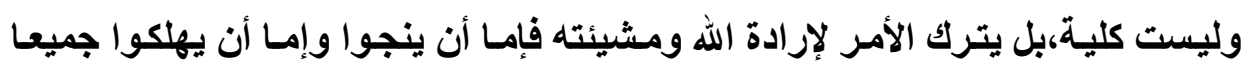

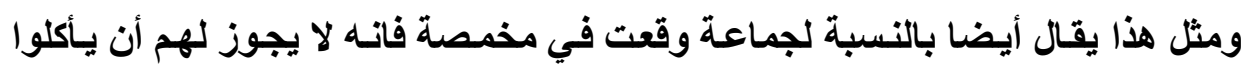

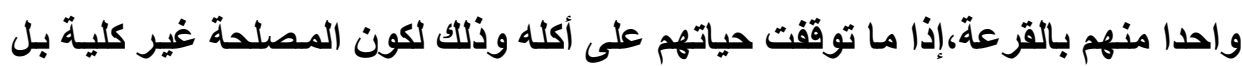
('). جزئية.

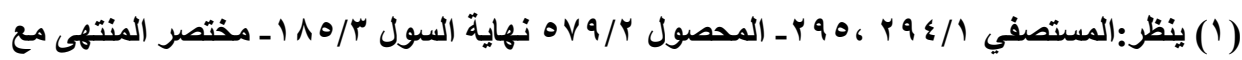

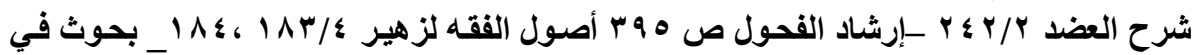

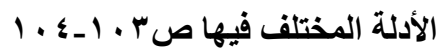




\section{المذهب الرابع: إن كانست المصلحة هلائمسة لأصل كلـي هـن أصسول السشرع،أو لأصل جزئي جاز بناء الأحكام عليها وإلا فلا.}

حكاه ابن برهان (') في الوجيز عن الثافعي وقال إنه الحق المختار('). وجاء في شرح العضد (")"وإن كان ملائما فقد صرح الإمام الغزالي بقبوله،ووقد

$$
\text { ذكر أنه مروي عن الثافعي ومالك" (") ("). }
$$

وذكر الثاطبي في الاعتصام فقال:"والثاني أن يلانم تصرفات الشرع وهو أن يوجد لذلك المعنى جنس اعتبره الشرع في الجملة بغير دليل معين وهو الاستـلال المرسل،/المسمى بالمصالح المرسلة.(()

(1) ابن برهان: هو أبو الفتح احمد بن علي بن محمد بن برهان الفقيه الثافعي،وكان متبحرا في الفقهـ

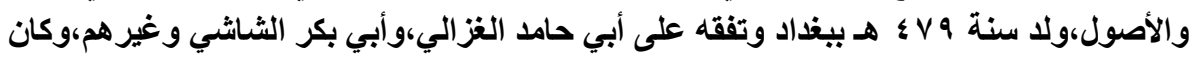

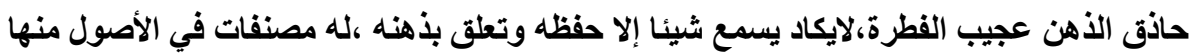

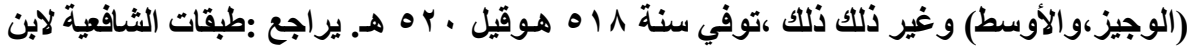

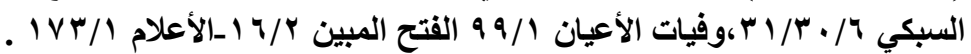

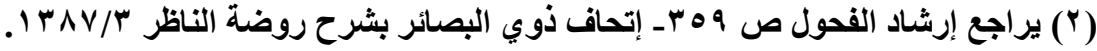

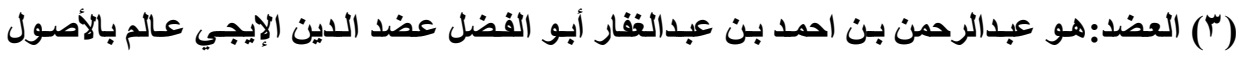

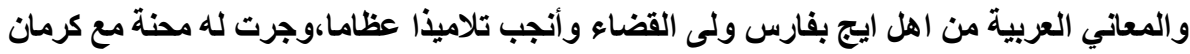

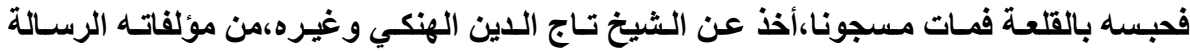

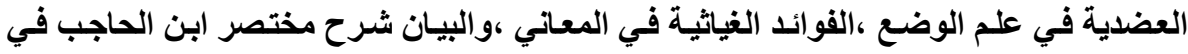

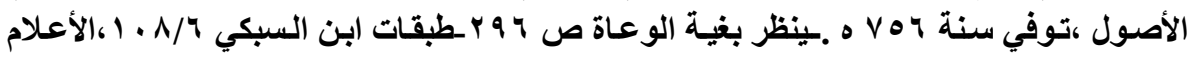

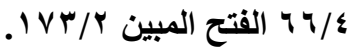

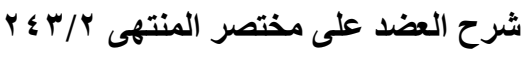

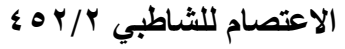




\section{المبحث الثاني \\ أدلة المذاهب على الاحتجاج بالاصالح المربلة المبئة \\ وبيان المذهب الراجح الاجناج}

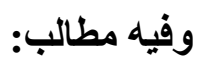

\section{المطاب الأول}

أدلـة المهذهب الأول: وهم القائلون بـان المصالح المرسلة ليست حجـة استلال

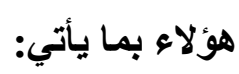

الـدليل الأول: إن المـصلحة المرسـلة متـرددة بـين المـصالح التـي اعتبرهـا

الشارع ،والمصالح التي ألغاها،وهذا يؤدي إلى احتمال أن تكون من المصالح المعتبرة

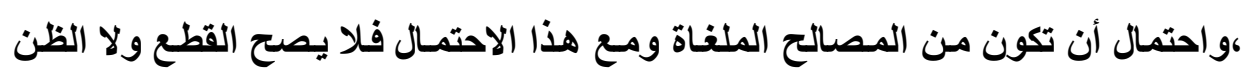
باعتبارها وبناء الأحكام عليها،لأن القطع أو الظن باعتبار ها يكون ترجيحا لأحد الأمرين المحتملين الذي هو الاعتبار على الآخر الذي هو الإلغاء بـون مرجح والترجيح بـلا مرجح لايجوز.

وإذا كان الأمر كذلك فلا يصلح أن تكون حجة في إثبات الأحكام الشرعية،لأن

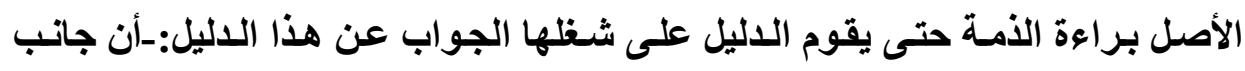
الاعتبار يرجح على جانب الإلغاء

لأنتـا لـو قارنـا بـين المـصالح التـي ألغاها،والمـصالح التـي اعتبرها،لوجـنا أن

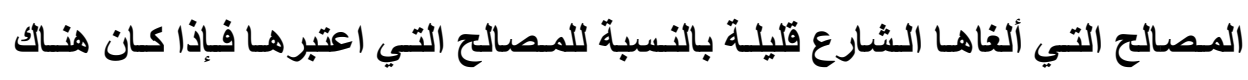
مصلحة لم يقم دليل على اعتبارها أو إلغائها ،كان الظـاهر إلحاقها بـالكثير الغالب وهو 
المصالح المعتبرة ،دون القليل النادر وهو المصالح الملغاة ،لأن ترك الخير الكبير لأجل الشر القليل شر كثير كما قال الإمام الرازي في المحصول.(') وأيـضا: فـانِ هذا الـدليل يمكن أن يبطل بـه رأي المنكـرين لحجيـة المـصالح المرسلة وذلك بأن نقول لهم : بأنكم قلتم بـأن المصالح المرسلة مترددة بين المصالح المعتبرة والمصالح الملغاة،فالقول بعدم اعتبارها مع هذا الاحتمال والتردد يكون ترجيحا لأحد الأمرين المحتملين وهو الإلغاء على الآخر وهو الاعتبار بدون مرجح وهذا لا

الدليل الثاني: إن الأخذ بالمصالح المرسلة في تشريع الأحكام يؤدي إلى فتح البـاب لذوي الأهواء ومن ليس أهلا للاجتهـاد ينفذون منـه إلى التصرف في الأحكام الثرعية. وينائها على ما يوافق أهواءهم ومصالحهم الخاصة،وفي هذا إهدار للشريعة وخروج عن قيودها وهو لا يجوز.

الجواب عن هذا الاليل سهل وبسيط وخصوصا إذا ما عرفنا أن من شروط الأخذ بالمصالح ألا يرد دليل يذل على اعتبار هـا أو إلغائهـا فبإن هذا الشرط يخرجها أن تكون في متناول العلماء الذين لم يبلغوا درجة الاجتهاد فضلا عن العوام وأهل الأهواء ،لأنـهـ. لا ياري أن هذه المصلحة لم يرد في اعتبارها أو إهمالها دليل شرعي إلا من كان أهلا

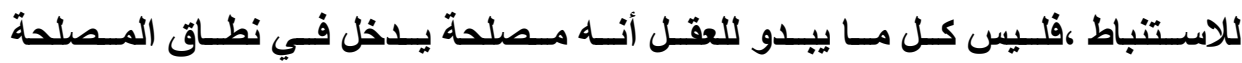
المرسـلة،وتبنى عليه الأحكام ،وإنمـا هي المـصالح التي يـاركها مـن هو أهل لتعرف

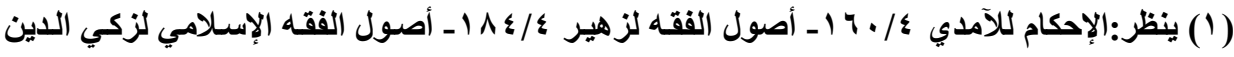

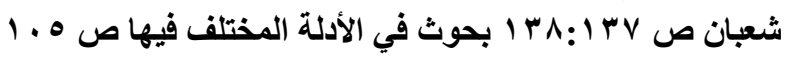


الأحكام الثرعية من مصادرها حتى يمكن الوثوق بأنسه لم يرد في الشريعة دليل على

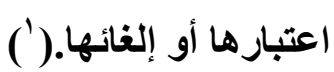

السدليل الثالـث: أنتا لو أخذنا بالمصلحة واعتبرناهـا أصلا قائمسا بذاته في تثريع الأحكام باختلاف الأزمان والبلان ،بل باختلاف الأثخاص في أمر واحد ،فيكون

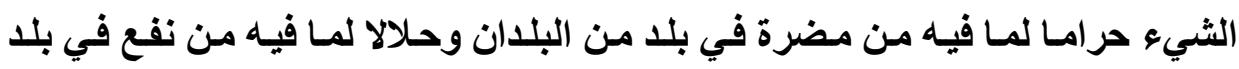

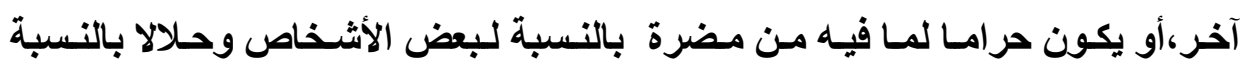

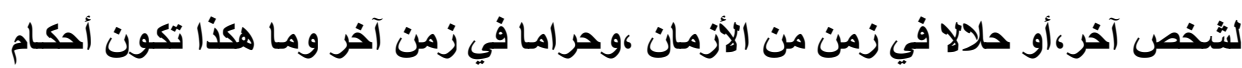

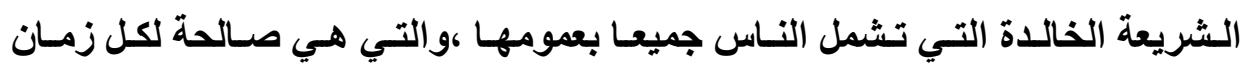

الجواب عن هذا الدليل: أن هذا لا يعد عيبا في الثريعة بل بالعكس يعتبر من

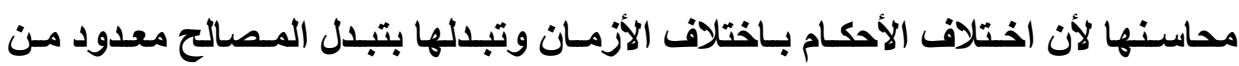
محاسن الثريعة لا من مساوئها وهو من الطرق التي تجعلها عامة وصـالحة لكل زمـان ومكان ،وإلا لما صلحت أن تكون خاتمة الثرائع.

و هذا الاختلاف ليس ناشئا عن الاختلاف في أصل الخطاب حتى يكون منافيا لعموم الثريعة كما تزعمون ،وإنما هو اختلاف ناثـئ عن التطبيق لأصل عام ودائم

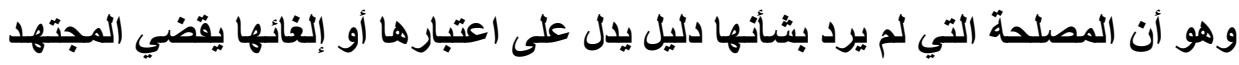

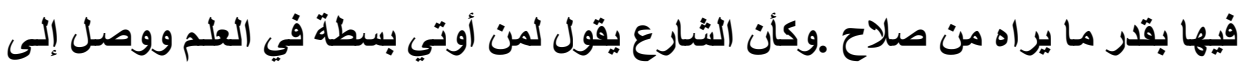
درجة تمكنه من الاجتهاد ، إذا عرض لك أمر من الأمور ورأيت فيه مصلحة محققة ولم الم

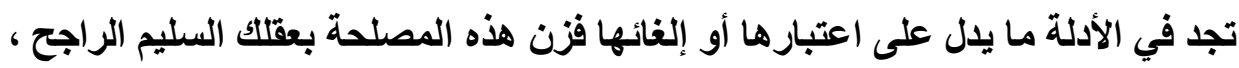

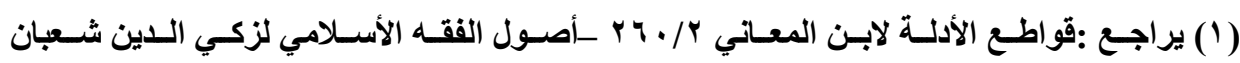

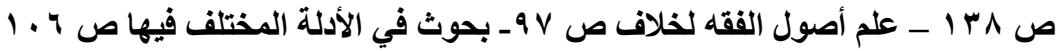


وقارن بينها وبين مايقابلها من مضار،فإن رجحت على المضار فاعتمدها واعمل بها

وإلا فأهملها وحرمها.(')

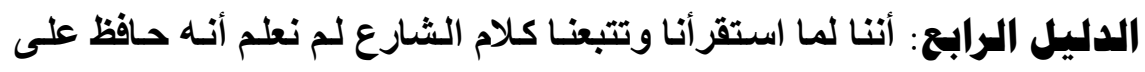
المـصلحة بكل طريق،بـل اختلف الحكم بـاختلاف متعلقـه فمـثلا الـماء لــ يـشرع في المحافظة عليها والزجر عن ارتكابها أبلغ ممـا شرع،فلم تشرع المثلة في القاتل عمدا وعدوانـا مـع أنها أبلـغ في الزجرعن القتل،وكذلك لـم يشرع القتل في السرقة،وشرب الخمر مع أنه أبلغ في الزجر عن العود لمثله ،فلم يشرع شيء من ذلك ،فلو كانت هذه اله

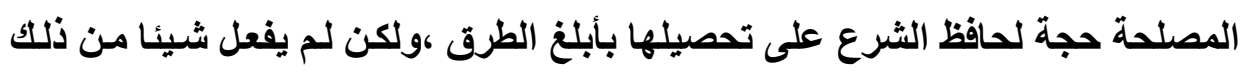

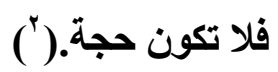

\section{الاطلب الثاني}

أدلة المذهب الثاني:وهم القائلون بحجية المصالح المرسلة وهؤلاء استدلوا بما يأتي: الــدليل الأول: مـا روي أن رسـول الله صـلى الله عليـه وســلم قـال لمعـاذ بـن جبل(") : كيف تقضي إذا عرض للك قضاء؟قّال أقضي بما في كتاب الله قـال:فبان لـم يكن

(1) ينظر أصول الفقه الإسلامي لزكي الدين شعبان ص ^^ץ ا ـ بحوث في الأدلة المختلف فيها ص $1 \cdot V$

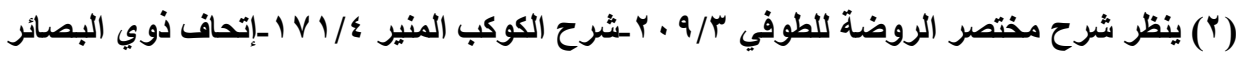
$1 \mathrm{r} \wedge \mathrm{O} / \mathrm{r}$ ("r) معاذ بن جبل بن عمرو بن أوس الأنصاري الخزرجي،شهـ بيعة العقبة والمشاهد كلها مـع رسول

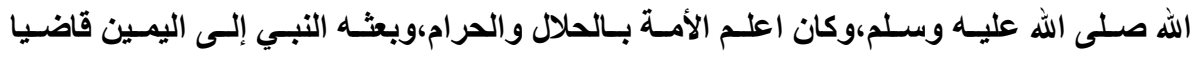

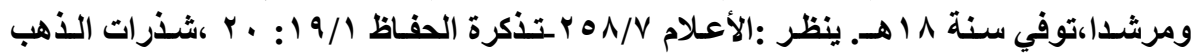


في كتاب الله؟ قال: فبسنة رسول الله قال:فِان لم يكن في سنة رسول الله ؟ قال أجتهـ رأيي ولا آلو أي لا أقصر في الاجتهاد والبحث "قال معـاذ فضرب رسول الله صلى الله عليه وسـلم صدري بيده وقال:الحمد لله الذي وفق رسول رسـول الله لمـا يرضسي الله ورسوله"( ).

وجه الاستدلال هن هذا الصديث: أن رسول الله صلى الله عليه وسلم أقر معاذاً على الاجتهاد بالرأي إذا لم يجد في كتاب الله أو السنة ما يقضي بـه ،والاجتهاد بـالر أي كمـا يكون بقيـاس الشيع على نظيره ،يكـون بتطبيق مبـادئ الشريعة والاسترشــاد بمقاصدها العامة ،والعمل بالمصالح المرسلة لا يخرج عن هذا،لأنه تشريع للحكم الذي لئي يحقق المصلحة العامـة للنـاس وتحقيتق المسالح هـو المقصود للشارع مـن تشريع

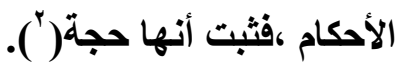

\section{الداليل الثاني: من الإجماع وبيان ذلك:}

أن الصحابة كانوا يبنون الكثير من الأحكام على المصالح المرسلة من غير إنكار على واحد منهم في ذلك فكان إجماعا منهم على العمل بالمصالح المرسلة والاعتداد بها في تثريع الأحكام.

(1) الحديث :رواه أبو داود في كتاب الأقضية باب اجتهاد الرأي في القضاء،وروراه الترمذي في كتاب

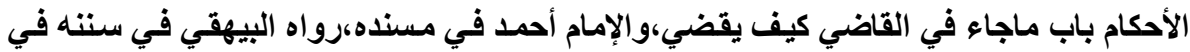

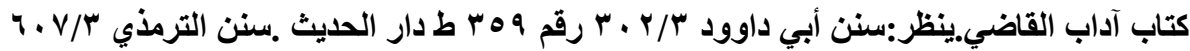

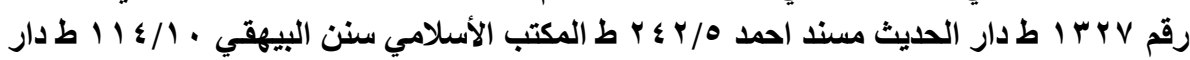

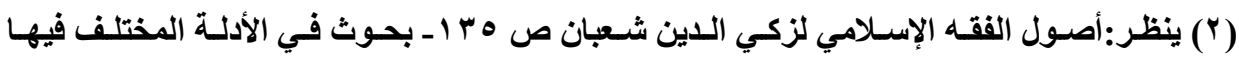

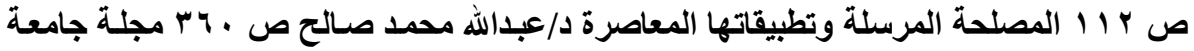


نوقش هذا الدليل بما يأتي:لا نسلم إجماع الصحابة على ذلك لأن دعوى الإجماع على اعتبار المصلحة المرسلة من الصحابة دعوى لا دليل عليها ،لأن الصحابة إنمـا

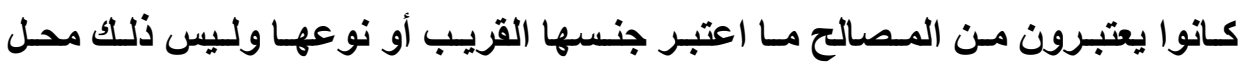

خلاف.) (')

الدليل الثالث:أن الثارع قد اعتبر جنس المصلحة في نوع الحكم،كمـا اعتبر جنسها في جنس الحكم ،واعتبار جنس المصالح في الجملة يوجب ظن اعتبار هذه المصلحة ، لكونها داخلة تحت الجنس فوجب اعتبار ها لأن العمل بالظن واجب. نوقش هذا الدليل :بأنه لو صح أن يقال :إن الثارع اعتبر المصلحة المرسلة

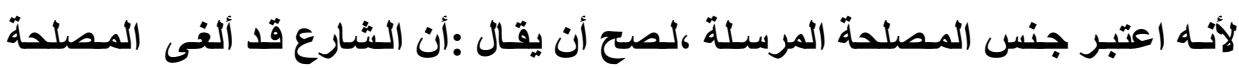
المرسلة لاشتر اكها مع المصلحة الملفاة في الجنس(ب) )،وبذلك تكون المصلحة المرسلة معتبرة وغير معتبرة ،وهذا تناقض. الدليل الرابع: إن المقصود من التشريع تحقيق مصالح النـاس بجلب الخير لهم ودفـع الشر والفساد عنهم،ولا ريب أن مصالح النـاس تتجـد بتجـد الزمسان ، وتختلف باختلاف البيئات ولا سبيل إلى حصرها في عدد معين ،فإذا لم تعتبر المصالح المتجددة ولم تشرع لها الأحكام المناسبة،ووقف التشريع عند المصالح التي دل الدليل المعين على اعتبارها لأدى ذلك إلى الضياع لكثير من مصالح النـاس المتجددة،وإلحاق الضرر والعنت بهم،ولأدى أيضا إلى جمود الشريعة وعدم مسايرتها لتطورات الحياة

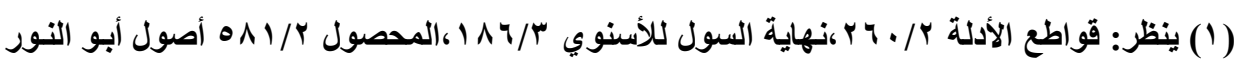

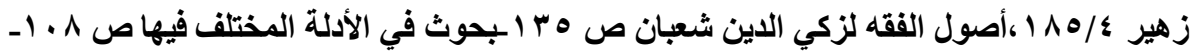

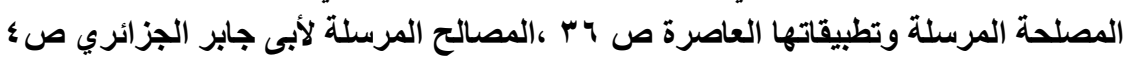

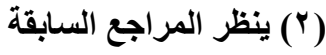


وتحقيـق الخيـر للنـاس ،وهـذا لا يتفـق مـع المقـصود بالتششريع الــي هـو تحقيـق

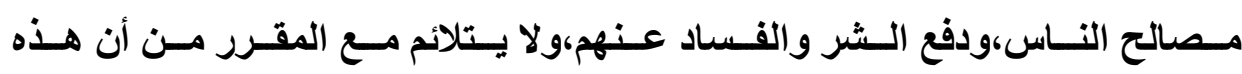
الشريعة ،شريعة خالدة قابلة للتطور والاستجابة لمطالب الأمس المختلفة في كل زمـان

ومكان.) (')

الدليل الفاهس : إنا قد علمنا أنها من مقاصد الثرع بأدلة كثيرة لا حصر لها في الكتاب والسنة وقرائن الأحوال والأمار ات،وسـوها مصلحة مرسـلة ولـم يسموها قياسا،لأن القياس يرجع إلى أصل معين بخلاف هذه المصلحة فإنها لاترجـع إلى أصل معين،بل رأينا الشرع اعتبرها في مواضع من الشريعة فاعتبرناهـا حيث وجدت لعلمنـا

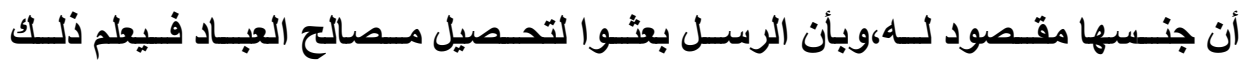
بالاسـتقر او،فمهما وجدنا مصلحة غلب على الظن أنها مطلوبـة للشرع فنعتبرهـا لأن

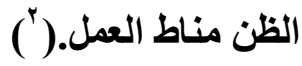

\section{الإطبا الثالث}

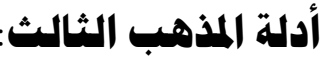

وهم القـائلون بحجية المصالح المرسـلة إذا توفرت فيـه الشروط الثلاثة بـأن

تكون المصلحة ضرورية،قطعية ،كلية. فهؤلاء استدلوا بما يأتي:

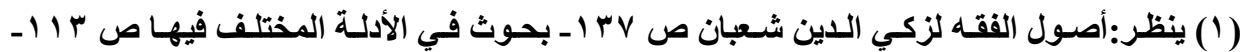

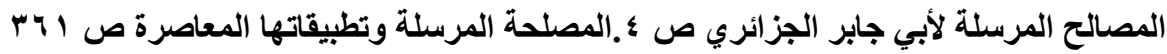

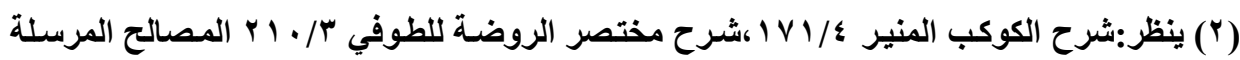

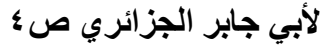




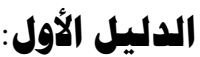

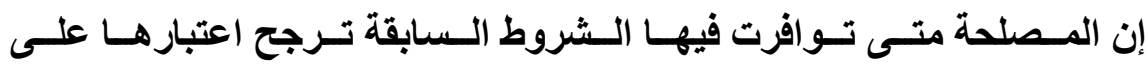
إلغاءها،فيكون الاعتبار مظنونا،وبذلك يكون المناسب في هذه الحالة حجة، لأن العمل

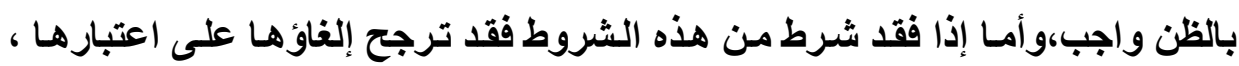

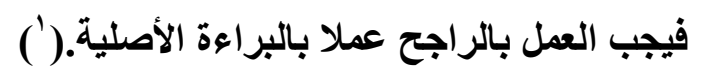

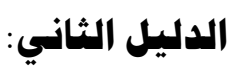

الاليل على اثبات القياس وهو اجماع الصحابة علي القول بالقياس ،ومستتدهم

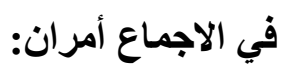

الأهر الأول: علمه بحال النبي صلى الله عليه وسلم ،ومقاصد الثرع في مراعاة

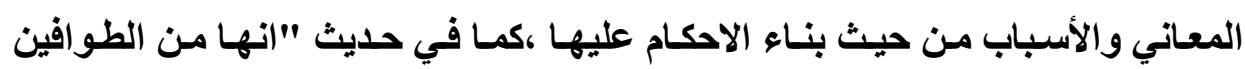

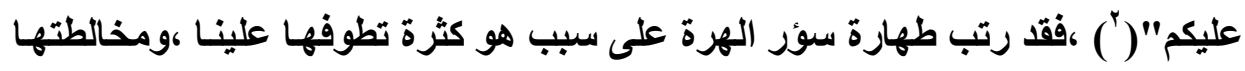
لنا.

الأهر الثاني: إذنه صلى الله عليه وسلم لهم في بنـاء الأحكام على المعاني التي

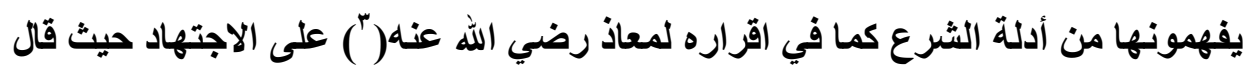

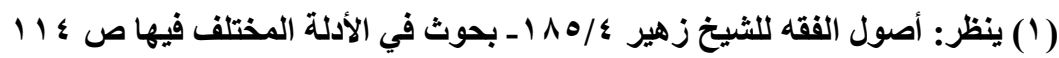

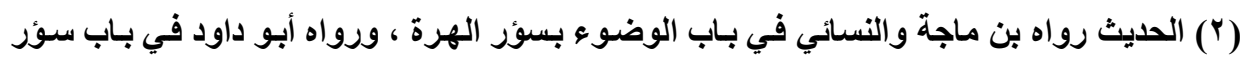

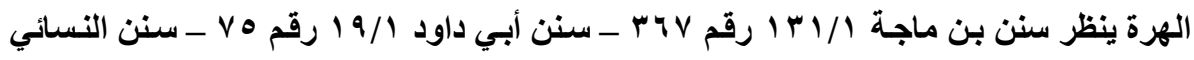


له "أجتها رأيي"(') والاجتهاد هو استتباط الاحكام واستخراجها على مـا فهموه من

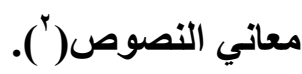

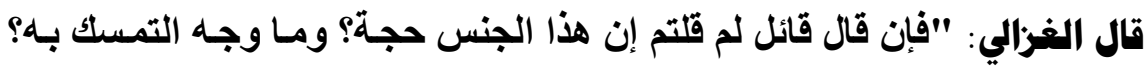
وما الدليل عليه؟ وقد اضطربت فيه مسالكك العلماء وقد قطعتم القول بقبولهه؟ قلنـا إنما

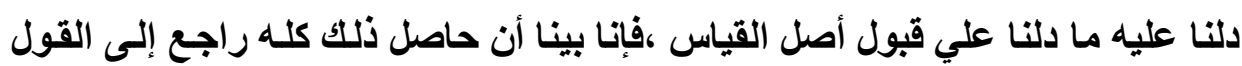

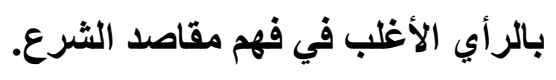

وإلى هذا يرجع ما يجوز التمسك به ،وكل مثنال نذكره ففيه دليل على قبوله إذا أظهرنا وجه الرأي فيه ويثها على جنس ذلك أمر كلي وهو مثال منقول عن الصحابة

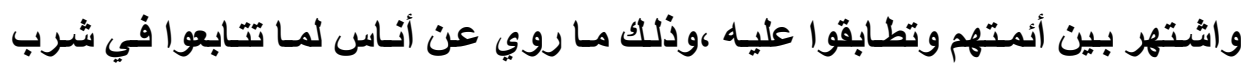

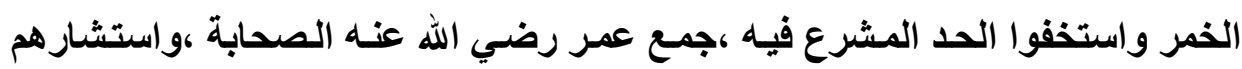

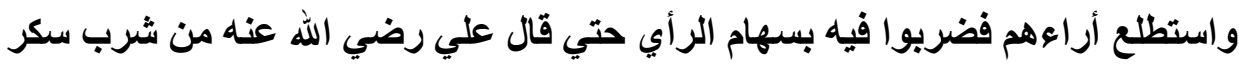

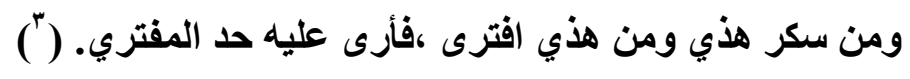

فأخذوا بقوله واستصوبوه واستمروا عليه ،وهذه هي المصلحة المرسلة التي

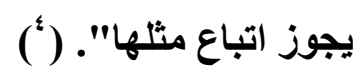

ثم قال "وعلى الجملة المفهومة من الصحابة اتباع المعاني ،والاقتصار في درك

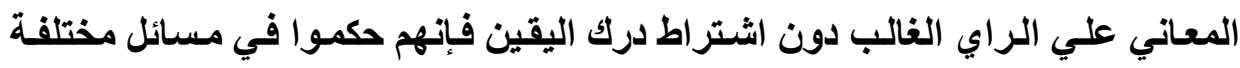

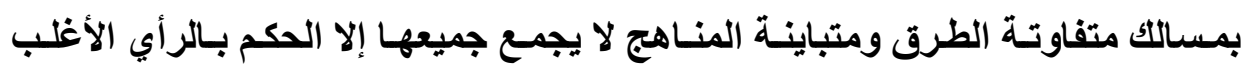


والأرجح وهو المراد بالاجتهاد الأي قرر النبي صلى الله عليه وسـلم معـاذا عليه فعلينـا

أن نتبين أن هذا يفيد غلبة الرأي.(')

فاتباع الصحابة للمعاني المأخوذة من نصوص الشرع يفيد حصول الظن الغالى بلرك الأحكام منها وذلك هو معنى الاجتهاد الأي أقر التبي صلى الله عليه وسلم عليه معاذا رضي الله عنه ،والاجتهاد معنى عام شـامل لاستتباط الأحكام بطريق القياس كمـا يشمل استنباطه بطريق فهمه من مقاصد الثرع ،والنظر في أدلته الإجماليه ،وهذا هو المعبر عنه بالمصلحة المرسلة ،وكلا الأمرين مفيد للحكم.

ولذا أجمع الصحابة على العمل بها اعتمـادا على الإذن لهم في الاجتهاد الشامل بها ،ويدل لهذا ما صرح به الغزالي ونصه" إن معاذ بن جبل قال" أجتها رأيي" حيث قال له رسول الله صلى الله عليه وسلم: "فإن عدمت النص" به فأثنى عليه رسول الله صلى الله عليه وسلم. وإعدام النص يشعر بـإعوازه ،وإعوازه المفهوم عنـه ،واجتهـاد الرأي مشعر

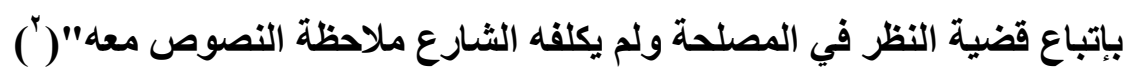
الدليل الثالث:

قال الغزالي "وكون هذه المعاني عرفت بـلا دليل واحد بل بأدلة كثيرة لا حصر

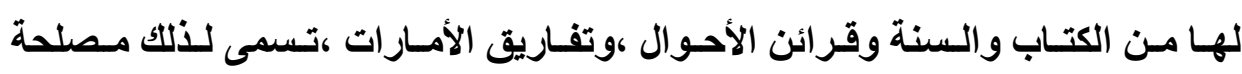


وإذا فسرنا المصلحة بالمحافظة على مقصود الشرع ،فلا وجـه للخـلاف في اتباعها ،بل يجب القطع بكونها حجة ، وحيث ذكرنا خلافا فذلك عند تعارض مصلحتين ومقصودين ،وعند ذلك يجب ترجيح الأقوى (') وما ذهب إليه هنا من أن اعتبار المصلحة المرسلة عرف لا بلديل واحد ،بل بأدلة

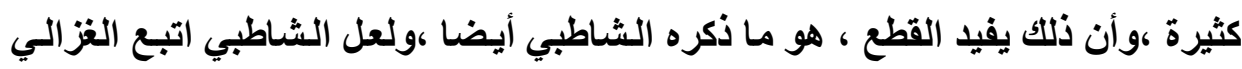

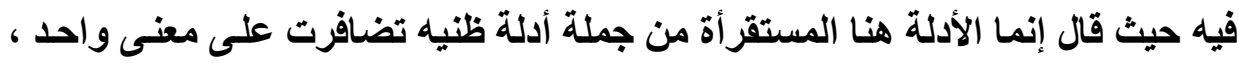

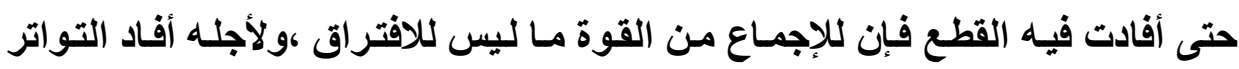

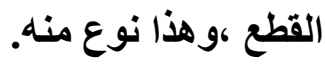

فإذا حصل من استقراء أدلة المسألة مجموع يفيد العلم فهو الدليل المطلوب ،

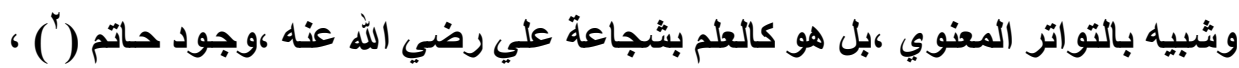
المستفاد من كثرة الوقائع المنقولة عنهما.

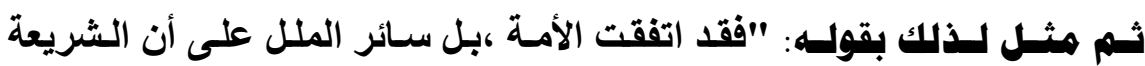
وضعت للمحافظة على الضروريات الخمس ،وهي: الدين ،والنفس ،والنسل ،والمـال ، والعقل ،و علمها عند الأمة كالضروري ولم يثبت لنا ذلك بـليل معين ولا شهـ لنسا أصل

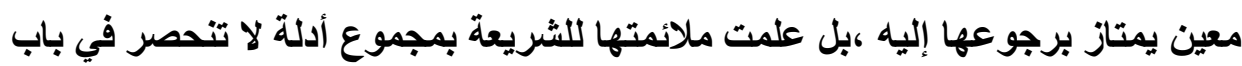

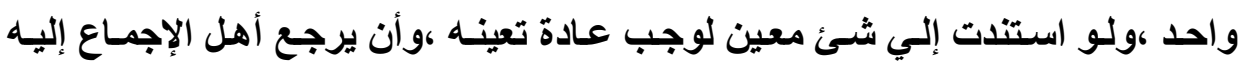

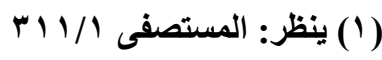

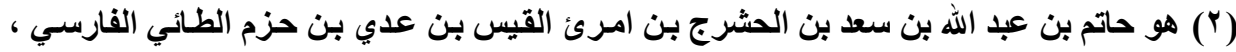

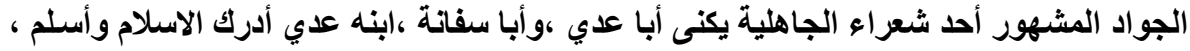

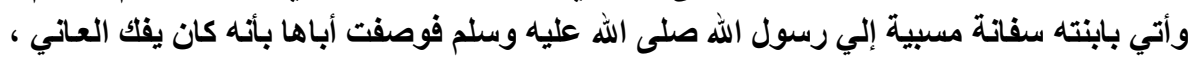

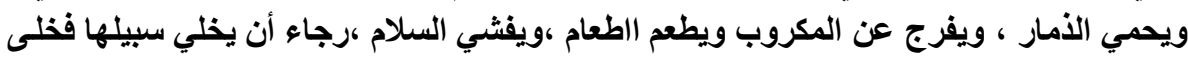

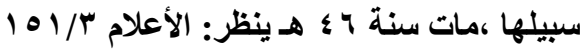


،وليس كذلك ،لأن محل واحد منها بـانفراده ظنـي ،ولأنـهـ كمـا لا يتعين في التواتر المعنوي وغيره أن يكون المفيد للعلم خبر واحد دون سائر الاخبار كذلك لا يتعين هنا

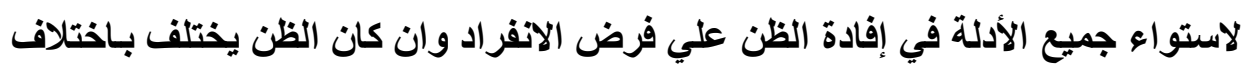

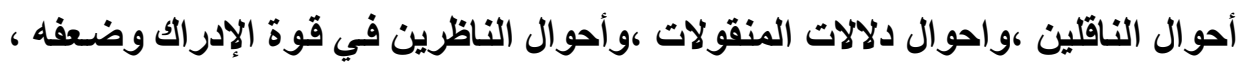

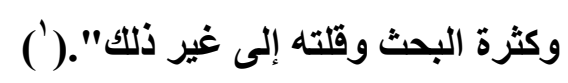

وعلى هذا يكون الغزالي قائلا بالمرسل ما لم تكن المصلحة فيه تحسينية ،شئنه في ذلك شأن غيره من الأيمة ولذا فهو يقول:"كل معنى مناسب للحكم مطرد في أحكام

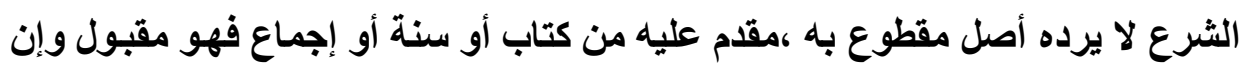

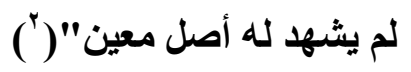

\section{المطالب الرابع}

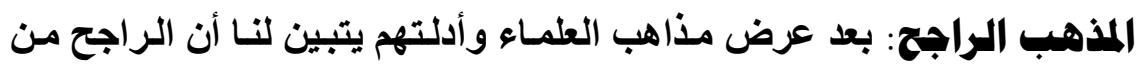

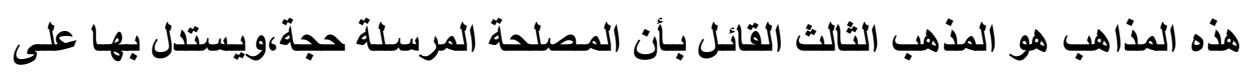

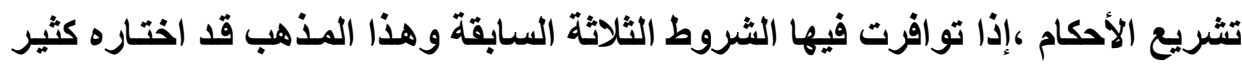
من الأصوليين ومن هؤلاء الإمام الغزالي ،والقاضي البيضاوي.(") والإمام الآمدي قد رجح أن يكون هذا المذهب هو مـا أراده الأمسام مالك،فقفال في

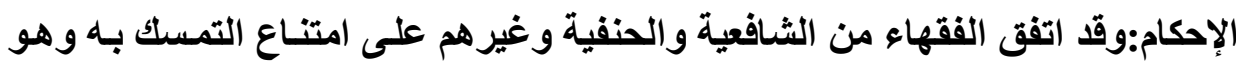

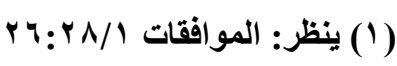

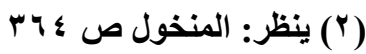

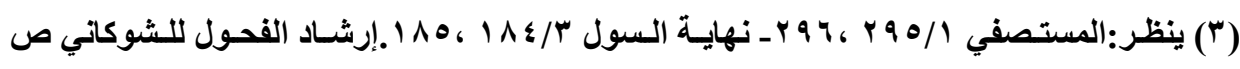


الحق إلا مانقل عن الإمام مالك أنه يقول به مع إنكار أصحابه لذللك عنهه،ولعل النقل إن صح عنه فالأثبه أنه لم يقل بذلك في كل مصلحة ،بل فيما كان من المصالح الضرورية الكليـة الحاصلة قطعـا لا فيمـا كـان من المـصالح غير ضروري ،ولا كلـي ،ولا وقوعـه

وقد رجح هذا المذهب أيضا بعض العلماء المحثثين فمن هؤلاء الثيخ محمد أبو

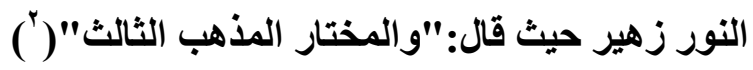

وقال الشيخ عبد الوهاب خلاف:والظاهر لي ترجيح بناء التشريع على المصلحة

المرسلة،لأنه إذا لم يفتح هذا الباب جمد التشريع الإسلامي ،ووقف عن مسايرة الأزمان والبيئات ،ومن قال:إن كل جزئية من جزئيات مصالح الناس في أي زمن وفي أي بيئة

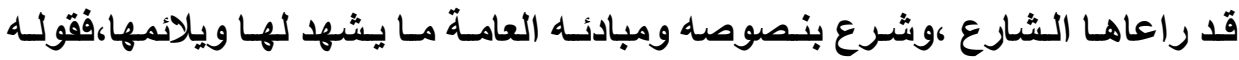
لايؤيده الواقع،فإنه مما لاريب فيه أن بعض المصالح التي تجد لا يظهر شـاهد شرعي على اعتبار ذاتها.

ومسن خـاف مـن العبـ والظلـم واتبـاع الهـوى باســم المـصلحة المطلقة يــفع

خوفه بأن المصلحة المطلقة لا يبنى عليها تشريع إلا إذا توافرت فيها الشروط الثلاثة

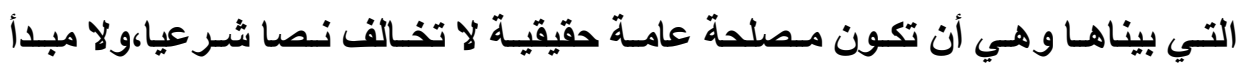

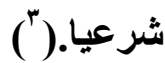

وقال الدكتور عبد الكريم النملة:" هذا المذهب هو المختار عندي،أي لا يجوز الاحتجـاج بالمـصلحة المرســة مطلقـا،ولا يجـوز ردهـا مطلقـا،ولكن يجـوز الاحتجـاج 
بالمصلحة المرسـلة بالشروط الثلاثـة السابقة وأزيــ شـرطا رابعا:وهو الملائمسة بين المصلحة الملحوظة،ومقاصد الشرع في الجملة بحيث لا تنـافي أصلا من أصوله ،ولا دليلا من أدلتـه القطعيـة،بل تكون مـن جنس المصالح الكلية التي قصد الشـارع إلى له تحصيلها أو قريبة منها،وليست غريبة عنها وإن لم يشه لها دليل خـاص بالاعتبار،ثم قال معللا اختياره واخترت ذلك لأمرين:

الأهر الأول:أن الأخذ بالمصالح المرسلة بالشروط السابقة هو الذي يتفق مـع روح الثريعة الإسلامية الذي جاعت برعاية مصالح العباد ،فطلبت منهم أو أباحت لهم كل مـا يجلب لهم النفع ،وحرمت عليهم أو كرهت لهم كل مـا يجلب لهم مفسدة أو

الأهـر الثـاني :أن هنـاك نـصوصا كثيرة وردت عن الشارع قد عللت الأحكـام بمصالح العباد،وما أثر عن الصحابة رضي الله عنهم من رعايـة المصالح في فتاويهم وقضاياهم ،كل ذلك يدل دلالة واضحة على أن المصلحة المرسلة معتبرة. ومـا نقل عن بعض العلمـاء أنـه ينكر العمل بالمصلحة المرسـلة ،فالظـاهر والله اعلـم أنسه ينكر الأخذ بها وهي مجردة عن تلك الشروط، أما المصلحة بتلك الشروط السابقة فقد أخذ بها جل مجتهدي الأمة.(') وقال الثيخ زكي الدين شـبان: أن القول بحجية المصالح المرسلة هو القول الراجح الذي تثهد له الأدلة ،والذي جرى عليه السلف الصالح من الصحابة والتابعين وأئمة الاجتهاد في العصور المختلقة ،وأن إنكار هذا المصدر مخالف للأدلة القائمة على 
حجيته ،وفيه فتح باب للطعن على الثريعة ورميها بـالجمود وعدم مسايرتها لتطورات الحياة وتحقيق الخير للناس.

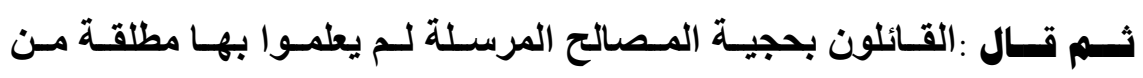

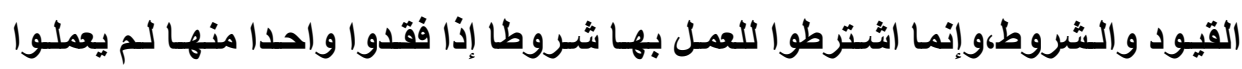
(') بها" (1)

رأي الباحث:

وبالنظر في هذه الأقوال المنسوبة إلي هؤلاء العلماء القدامى والمحدثين وأدلتهم فإنتي أتفق معهم علي أن العمل بالمصلحة المرسلة حجـة متى توفرت فيها الشروط

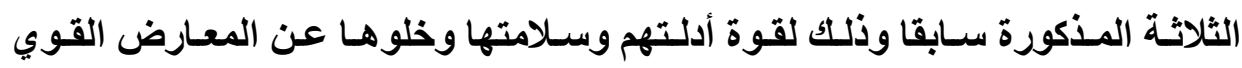
وضعف أدلة المخالفين ومناقشتها. ولولا العمل بالمصلحة لخلت كثير من الوقائع عن وجود أحكام لها وهذا يتـافى مع مقصود الشارع وأيضا لو لم يعمل بالمصلحة لا تصف التشريع الاسـلامي بـالجمود والتأخر وعدم مسايرة العصر وهذا يتـافى مـع النصوص الدالة علي مرونـة التشريع الاسلامي وصلاحيته لكل زمان ومكان. 


\title{
الفصل الثالث
}

أثر الاحتجاج بالمالح المرسلة في الفقه الإسلاهي

\author{
وفيه هباحث

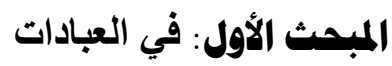 \\ المبحث الثاني: في المعاملات \\ المبحث الثالث: في العقوبات
}

\section{المبحث الأول \\ في العبادات}

\section{الفرع الأول \\ جمع الناس على قارئ واحد في صلاة التراويح.}

كان الناس على عهل رسول الله صلى الله عليه وسلمهوخلافة أبي بكر رضي الله

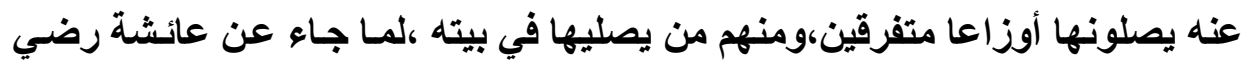

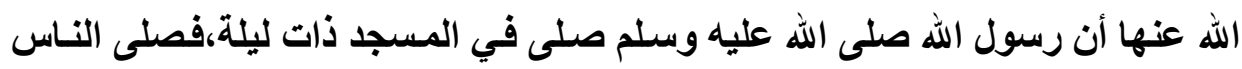
بصلاته،ثم صلى الليلة القابلة فكثر الناس ،ثم اجتمعوا من الليلة الثالثة أو الرابعة فلم فله 
يخرج إليهم رسول الله صلى الله عليه وسلم فلما أصبح قال"قد رأيت الذي صنعتمولم

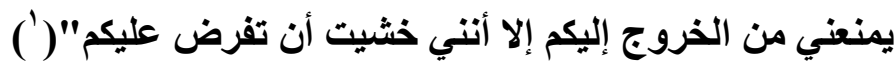

قـال ابن شـهاب الزهري(")"فتهوفي رسـول الله صلى الله عليه وسـلم والأمر

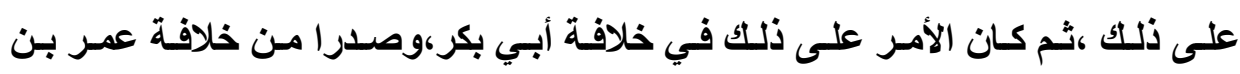

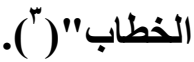

فلما كانت خلافة سيدنا عمر رضي الله عنه وكثر الناس وارتفعت الأصوات في

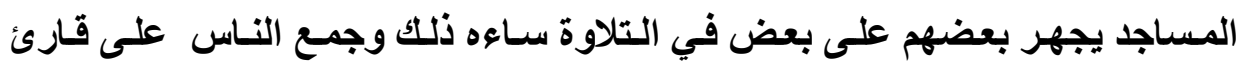

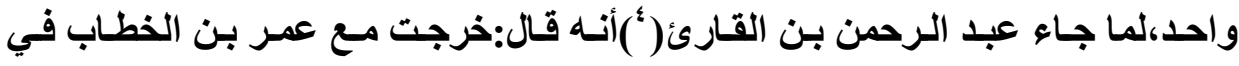
رمضان إلى المسجد فإذا الناس أوزاع متفرقون،يصلي الرجل لنفسه،ويصلي الرجل فيصلي بصلاته الرهط ،فقال عمر والله إني لأراني لو جمعت هؤلاء على قارئ واحد

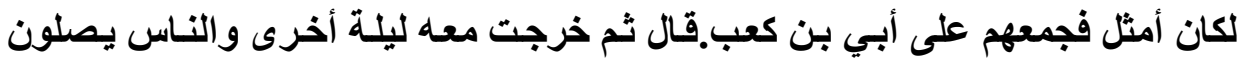

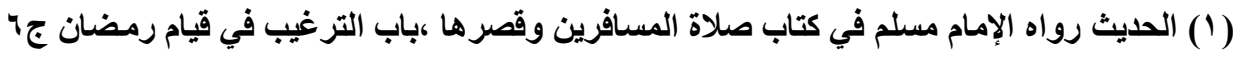

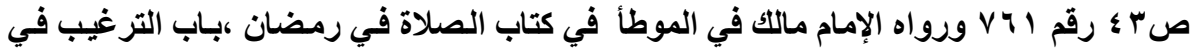

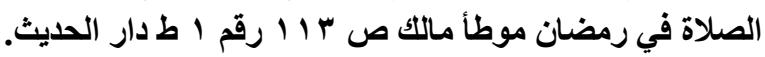

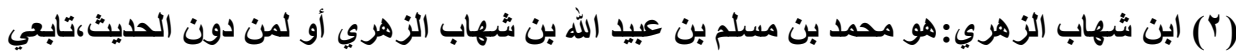

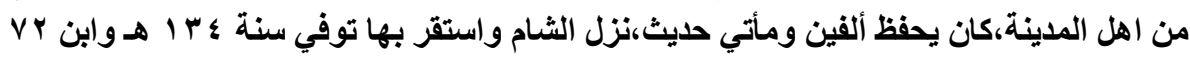

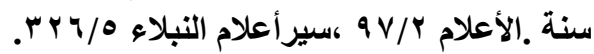

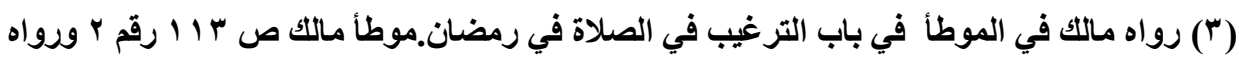

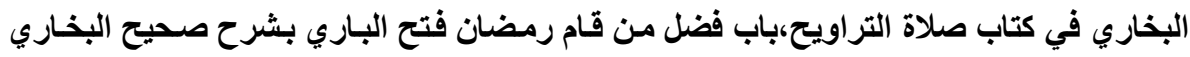

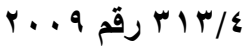

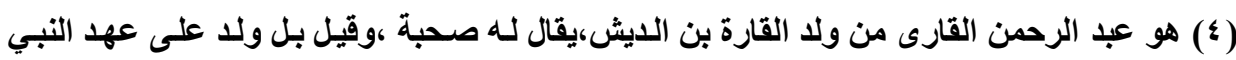

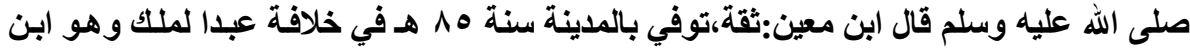

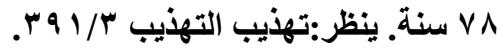


بـصلاة قارئهم،فقـال عمـر:نعمـت البدعـة هـذه ،والتـي تنـامون عنهـا أفضل مـن التـي تقومون،يعني أخر الليل وكان الناس يقومون أوله.(') ووجه دخول هذا المثال تحت المصالح المرسـلة هو أن جمع النـاس على قـارئ

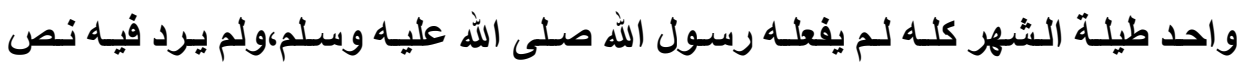
خاص،ولم يفعله سيدنا أبو بكر وهو أحرص من سيذنا عمر علي تطبيق الخير لو كـان موجودا.ولكن ما فعله عمر كان ملائمسا لمقصود الشارع،لأن مجموع النصوص جاءت شاهدة ومتشوقة لوحدة المسلمين ومن مظاهرها صـلاة المسلمين خلف إمسام واحد،لما تحدثه من تآلف وترابط في صفوف المسلمين،وعندها يتحقق فيهم قوله تعالى:"إن الله يحب الأين يقاتلون في سبيله صفا كأنهم بنيان مرصوص"( ) وأثر ذلك في الفقه الإسـلامي هو منع التشويش للمصلين بعضهم على بعض،

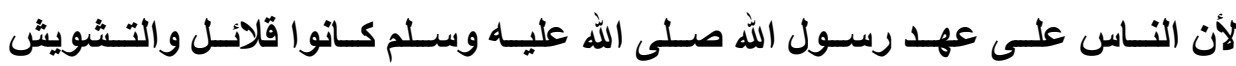

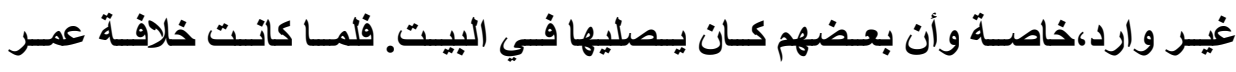

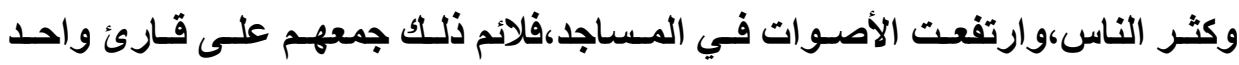
حتى لا يشوش بعضهم على بعض ،ولكي ينشط ضعاف النفوس إلى قيام رمضان ولو لم تثرع صلاة التراويح جماعة في المسجد لتركها ضـعاف النفوس خاصـة في عصرنا 


\section{الفرع الثاني \\ العمل القليل في الصلاة لا يبطلها ،بخلاف العمل الكثير.}

أجمت الأمة على أن العمل القليل لا يبطل الصلاة،وان العمل الكثير يبطلها،وحد

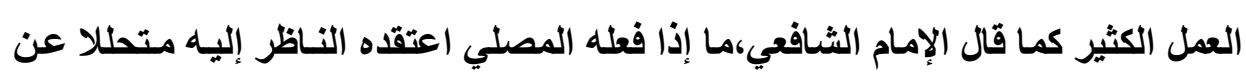
الصلاة وخارجا عنها ،كما لو اشتخل بالخياطة والكتابة وما غير ذلك ،والعمل القليل:مالا يعتقد الناظر إليه مرتكبه خارجا عن الصلاة كتسوية ردائهه ومسح شعره ،وليس لهذا لئا التقدير أصل خـاص يستند إليه،وإنما استتد إلى أصل كلي،وهو أن الصلاة مشروعة

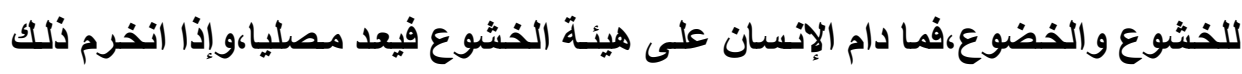

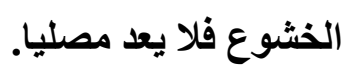

وهذا المثال ذكره الإمـام الزنجاني في كتابـه تخريج الفروع على الأصول بنـاء

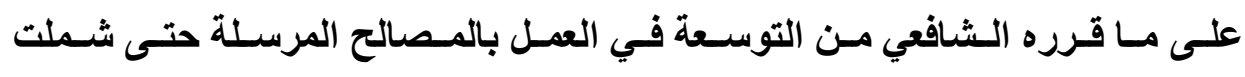

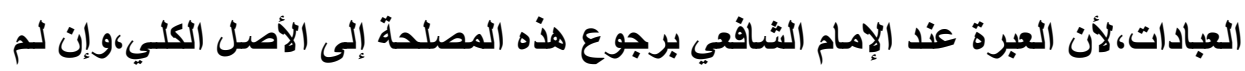

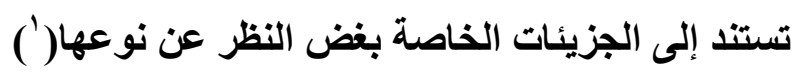

\section{الفزع الثالثث \\ زيادة الأذان الأول يهم البمهمة}

لماز زاد الناس وكثروا في عهز عثمان بن عفان رضي الله تعسلى عنه زاد الآذان الأول لصلاة الجمعة ،وجعله على دار في سوق المدينة تسمى بـالزوراء ،وهو الآذان

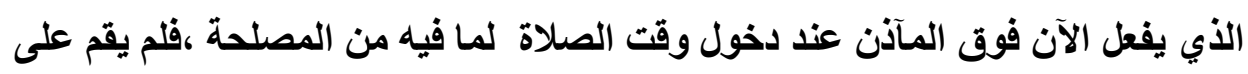

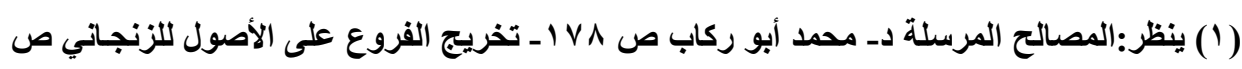

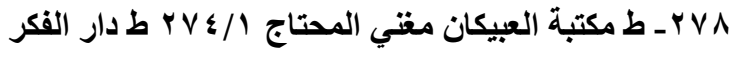


هذا الآذان دليل من كتاب أو سنة أو إجماع أو قياس ،ولكن سيدنا عثمان بنى هذا الحكم

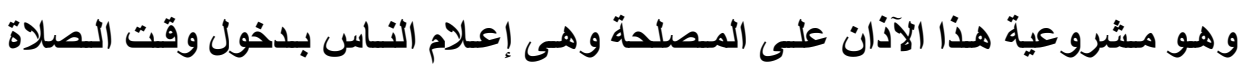

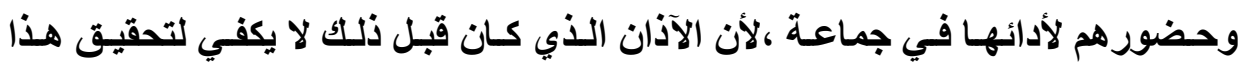

الغرض الذي شرع الآذان من أجله (').

جاء في البخاري ما يشهد لذلك فقد جاء فيه "كـان الآذان على عهد رسول الله حين يجلس الإمام على المنبر ،فلما كثر الناس في عهر عثمان أمرهم بآذان آخر على على

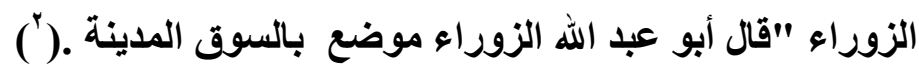

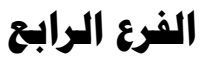

\section{جمع القرآن في هصصف واحد}

اتفق أصحاب الرسول صلى الله عليه وسلم على جمع القرآن في مصحف واحد بعد أن كان متفرقا في عدة صحف وألواح ،ولم يكن هذا الجمع في عهد رسول الله صلى اله الله عليه وسلم ،بل حلث في عهد أبوبكر الصديق بعد أن أشـار عليه عمر بذانلك ،ولم

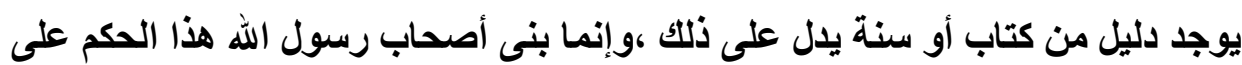

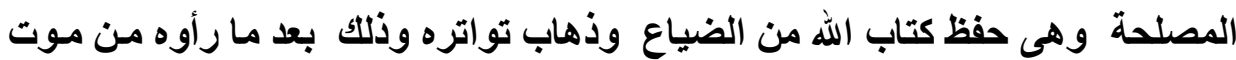
كثير من الحفظة في الحروب ("r)،وقد جاء هذا الجمع تحقيقا لقوله عز وجل "إنا نحن

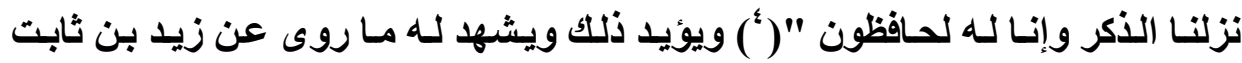

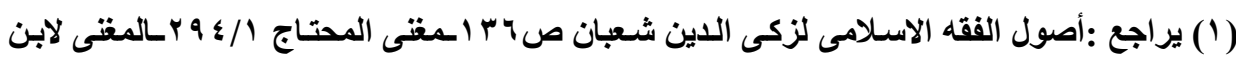

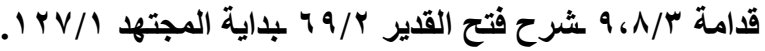

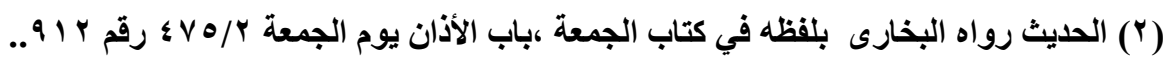

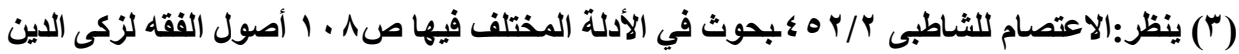

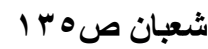

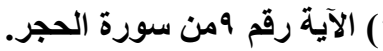


رضي الله عنه أنه قال :أرسل إلى أبو بكر رضي الله عنه عقب مقتل أهل اليمامـة ،وإذ بعمر بن الخطاب عنده ،فقال أبو بكر " إن عمر أتاني فقال :إن القتل استحرى بقراء الفراء القرآن يوم اليمامة ،واني أخثى أن يستمر القتل بالقراء في المواطن كلها فيذهب قرأن أنمان

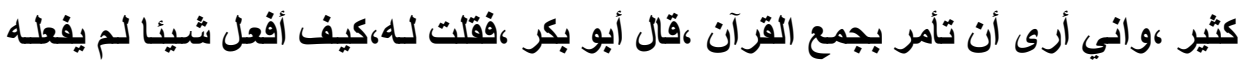
رسول الله صلى الله عليه وسلم ،فقال لي هو والله خير ،فلم يزل عمر يراجعني في ذلك التك حتى شرح الله صدري لله ورأيت فيه الذي رأى عمر ،قال زيد:فقال أبو بكر :انكل رجل

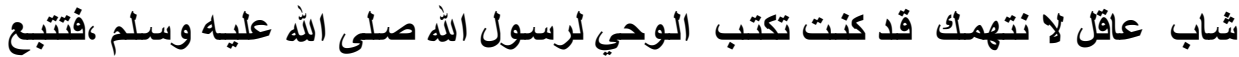

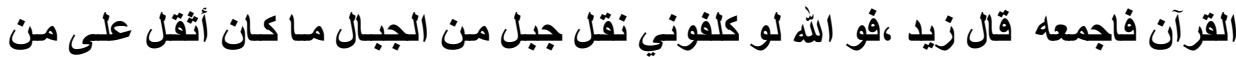

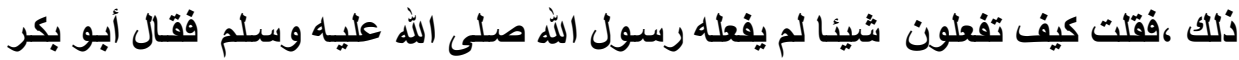

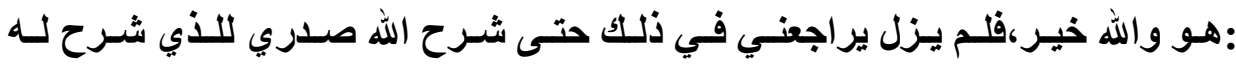

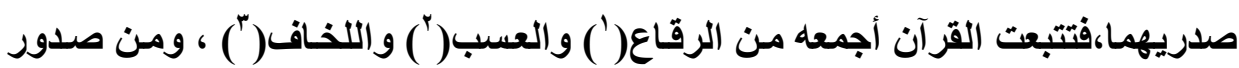

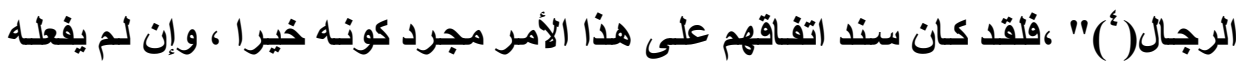

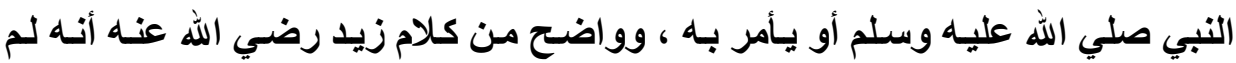

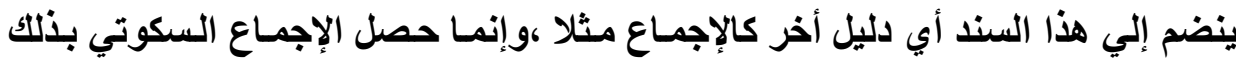
بعد بدء زيد بالكتابة والجمع وهو لا يعد سند أو جزء سند لمسا اتفق عليه الثثلاثة ،لأنه

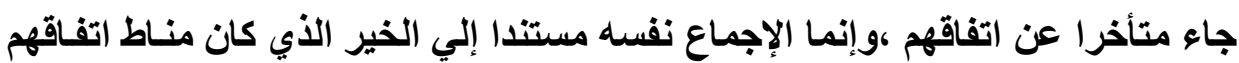
شأنه شأن أي دليل شرعي لابد أن يستند إليه الإجماع( ).

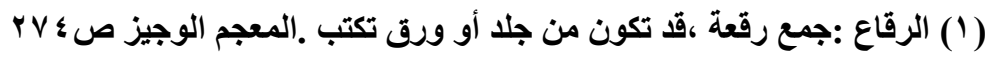

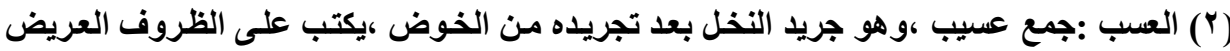

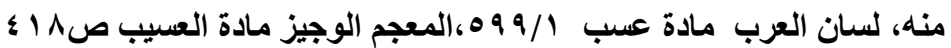

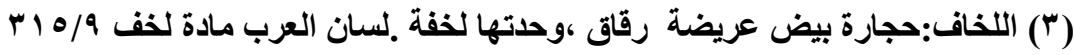

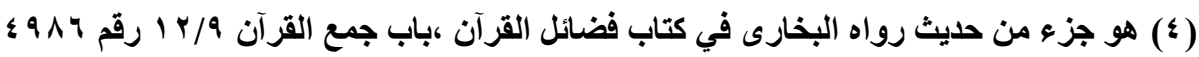

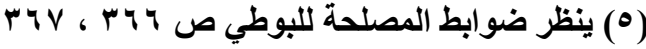




\section{"المبحث الثاني "}

\section{في المعاهلات}

\section{الفرع الأول \\ فرض ضرائب على الأغنياك}

إنا إذا قررنا إماما مطاعا مفتقرا إلى تكثير الجنود لسد الثغور وحمايـة الملك المتسع الأقطار،وخـلا بيت المـال عند الحـال،وارتفعت حاجـات الجنــ إلى مـال يكفيهم فللإمام إذا كان عدلا أن يوظف على الأغنياء ما يراه كافيا لهم في الحال إلى أن يظهر مال بيت المال ،ثم إليه النظر في توظيف ذللك على الغلات والثمار وغير ذلك كيلا يؤدى تخصيص الناس به إلى إيحاث القلوب ،وذلك يقع قليلا من كثير بحيث لا يجحف بأحد ويحصل الغرض المقصود .

ومثل هذا لم يكن موجودا عند الأولين لاتسـاع مال بيت المال في زمـانهم بخلاف

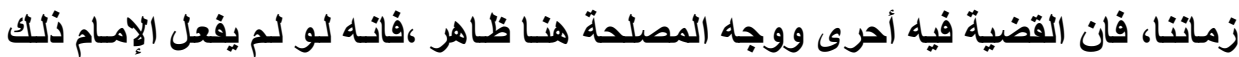
النظام بطلت شوكة الإمام ،وصارت ديارنا عرضة لاستيلاء الكفار.(') الفزرع الثاني

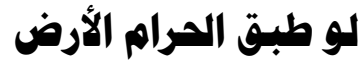

لو طبق الحرام الأرض أو ناحية من الأرض يعر الانتقال منها ،وانسدت طرق

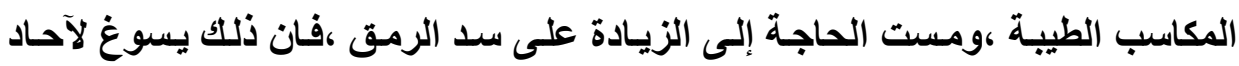

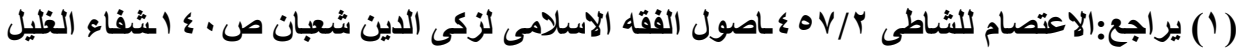

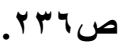


الناس إذا لم يستطيعوا تغيير الحال وتعذر الانتقال إلى الأرض تقام فيها شريعة الله

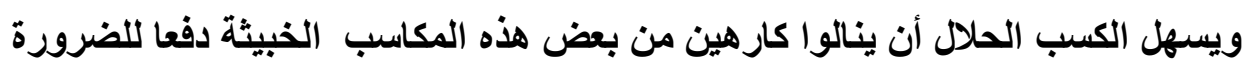

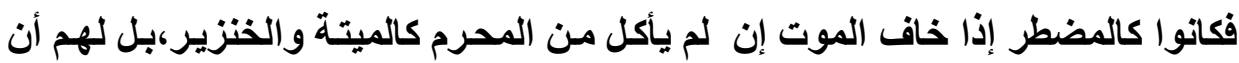

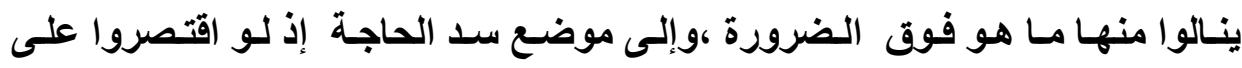
الضرورة لتعطلت المكاسب والأثغال ولاستمر الناس في مقاستات ذلكت إلى أن يهلكوا وفي ذلك خراب الدين والدنيا ،ولكنهم لا يتجاوزون موضع الحاجة إلى الترفه و النعيم

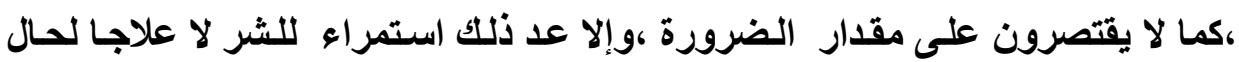

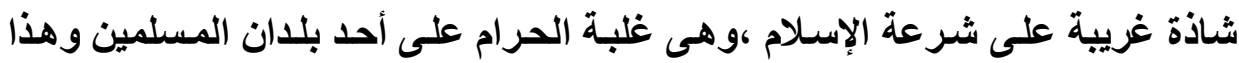

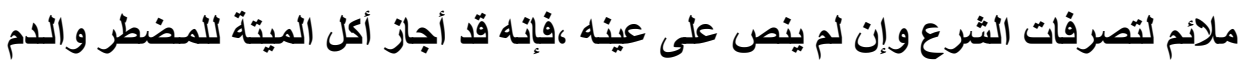
ولحم الخنزير ،وغير ذلك من الخبائث و المحرمات(') .

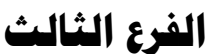

\section{تضمين الصناع}

إن الخلفـاء الراشدين قد قرروا تضمين الضياع للمصلحة مـع أن الأصل أن

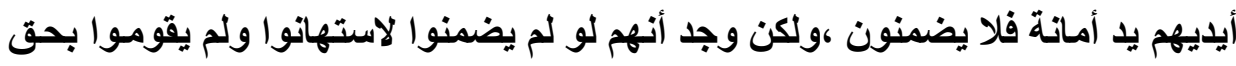

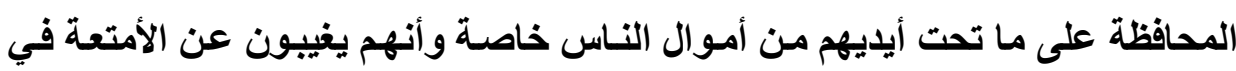

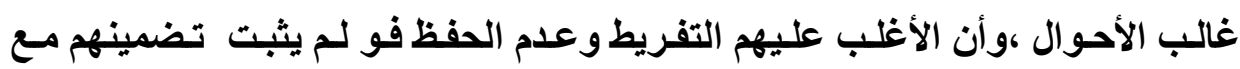
مسيس حاجة الناس إليهم و إلى استعمالهم لأفضى ذللك إلى أحد أمرين: 1- إما ترك الاستصناع بالكلية وذلك شاق على الخلق.

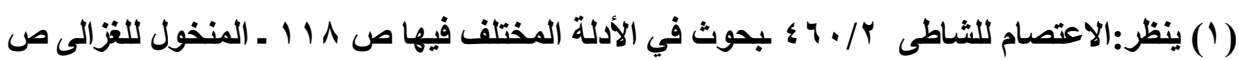
r 
r- وإما أن يعملوا ولا يضمنوا ذلتك بـعواهم الهلاكت والضياع فتضيع الأمسوال ويقل الاحتراز وتتطرق الخيانة،فكاتت المصلحة التضمين ،وكان الأسـاس في التضمين

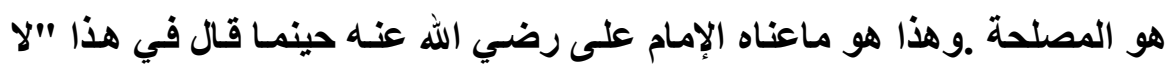

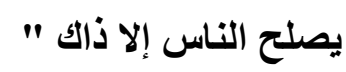

وقد يعترض عالى هذا بأن هذا العمل وهو تضمين البرئ نوع من الفساد ، إذ لعله مـا أفسد ولا فرط ، فتضمينه مع ذلك نوع من الفساد ـ من ون ويماب عن ذلك: انه إذا تقابلت المصلحة والمضرة ،فشأن العقلاء النظر إلى التفاوت ،ووقوع التلف من الصناع من غير مسبب ولا تفريط بعيد ،والغالب الفوت فوت الأموال ،وإنها لا تستتد إلى التلف السماوى ،بل ترجع إلى صنع العباد على المباشرة أو التفريط وفي ولهي الحديث "لاضرر ولا ضرار"' ما تثهـ لله الأصول من حيث الجملة فِان النبي صلى الله

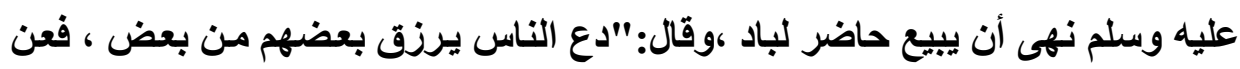

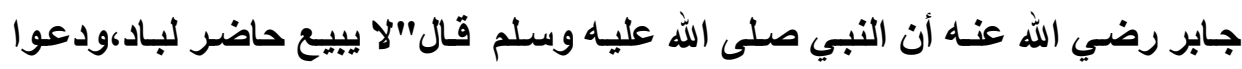

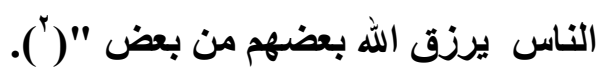

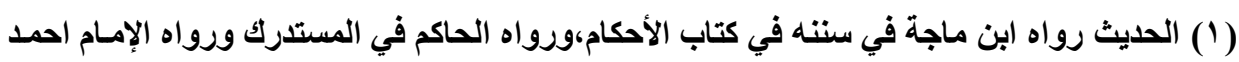

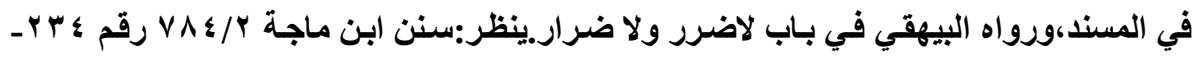

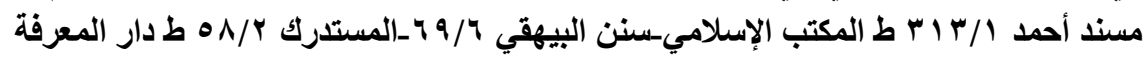

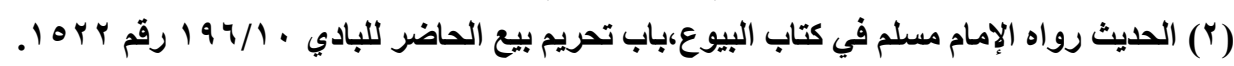


وعن عمر رضـي الله عنهمـا قـال:"نهـى النبـي صلى الله عليهـ وسـلم أن يبيع

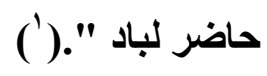

وهو من باب ترجيح المصلحة العامة على المصلحة الخاصةة، فتضمين الصناع

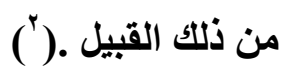

\section{الفرع الرابع}

\section{توريث المطلقة طلاقا بائنا في هرض الموت}

أن سيدنا عمر بن الخطاب ،وعثمان بن عفان رضي الله عنهما قضوا بتوريث

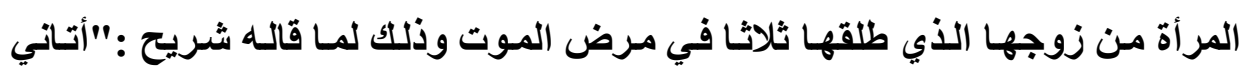

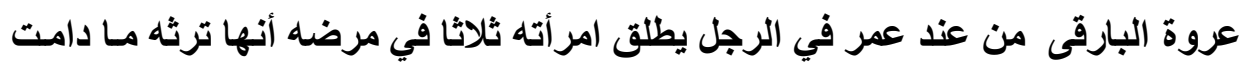

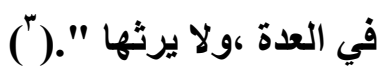

وعن عطاء :أن امرأة عبد الرحمن بن عوف كاتت عنده على تطليقه فأبانها ،

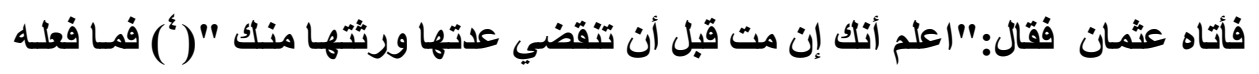
عمر وعثمان وغيرهم من الصحابة من توريث البائنة في مرض الموت لـم يرد فيـه

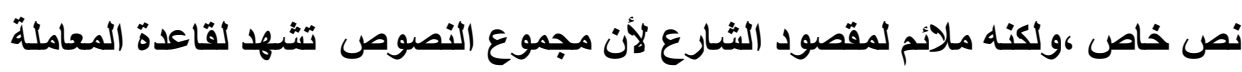
بنقيض المقصود.

( ) رواه البخاري في كتاب البيوع باب من كره أن يبيع حاضر لباد بأجر. ينظر فتح الباري بشرح

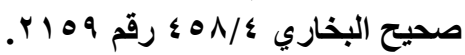

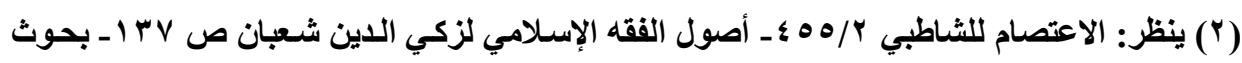

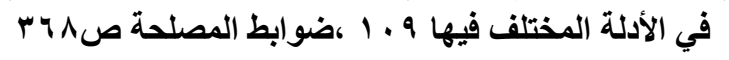

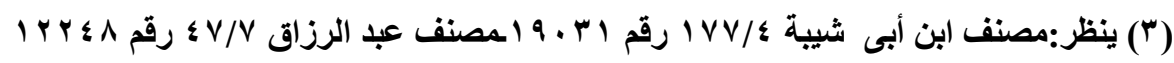

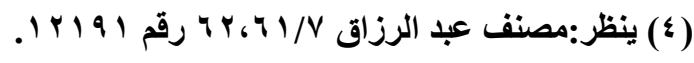




\section{ويترتب على توريثها هصلتتان}

الأولى : مادية يعود نفعها على الزوجة ،والثانية اجتماعية ،يعود نفعها عليها

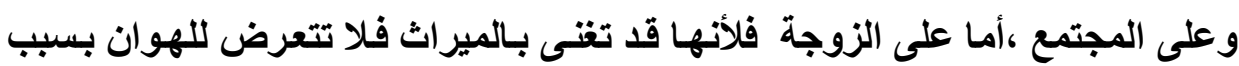

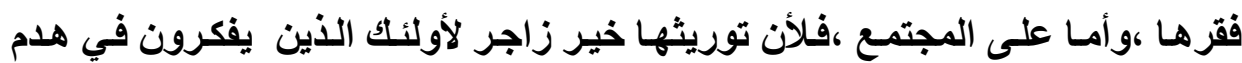

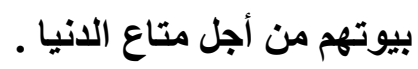

فهذا الحكم لم يكن موجودا على عهد رسـول الله صلى الله عليه وسـلم ،لأن

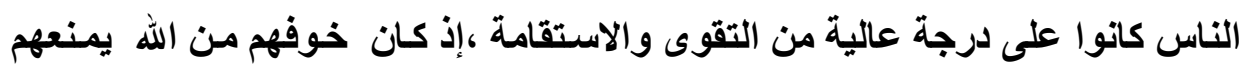

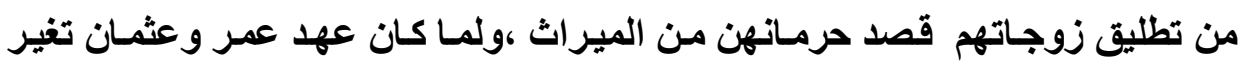

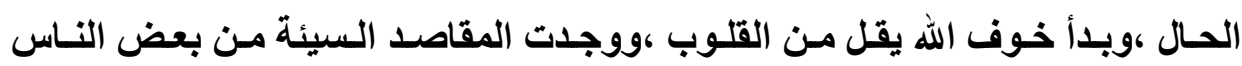

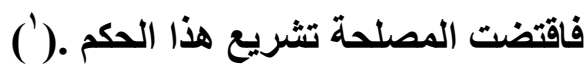

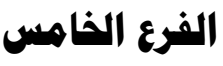

\section{هشاطرة الولاة أهوالهم}

إن عمر بن الخطاب كان يشاطر الولاة الذين يتهمهم أموالهم لاختلاط أموالهم

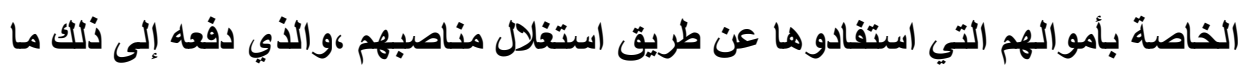
رآه من المصلحة حيث أنه بعمله هذا قد ضمن صلاح الولاة ومنعهم من استغلال سلطان

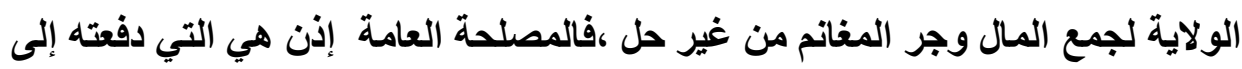

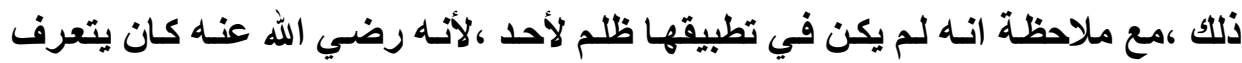

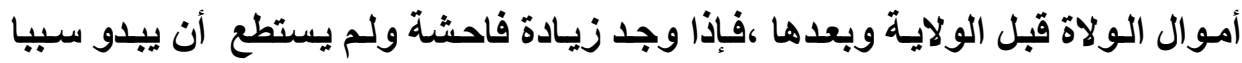

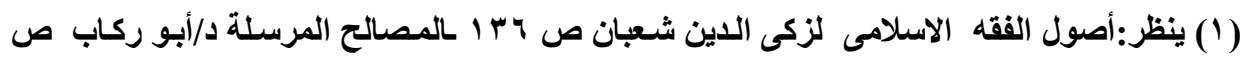

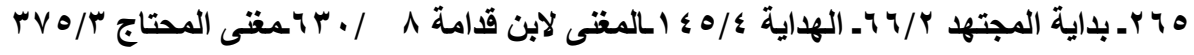




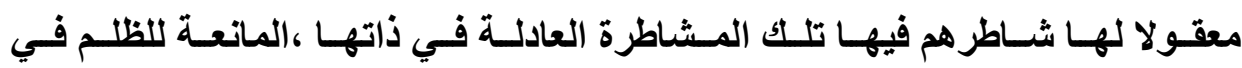

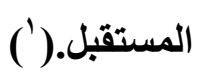

\section{الفرع السادس}

\section{تهديد رواتب وعطاءات هوظفي الدولة}

لم يكن للعمال والموظفين رواتب محددة على عهد رسول الله صلى الله عليه وسـلم - ولا على عهد أبى بكر رضس الله عنه،ووإنمـا كـانوا يعطون بحسب الظروف والأحوال .فلما كاتت خلافة عمر بن الخطاب رضسي الله عنه حدد الرواتب ،وجعل لكل موظف راتبا خاصا.وقد اهتم رضي الله عنـه اهتمامـا خاصـا برواتب القضاة ، فأعطاهم

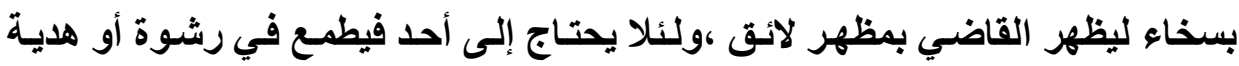

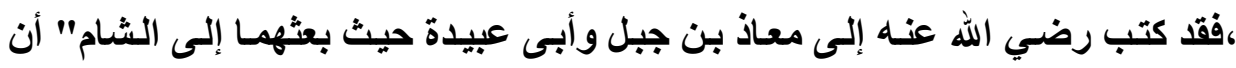
انظروا رجـالا مسن صـالحى مسن قبلكم فاسـتعمولهم على القضاء وأوسـعوا عليههم،

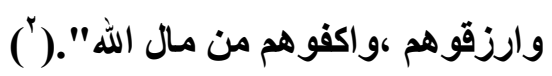

فهذه سياسته رضسي الله عنه في التوسـعة على المسلمين بمسا فيهم مـوظفي الاولة ، خاصة إذا كانوا قضاة ، على خلاف ما يتصوره عنه بعض النـاس من انـه كـان

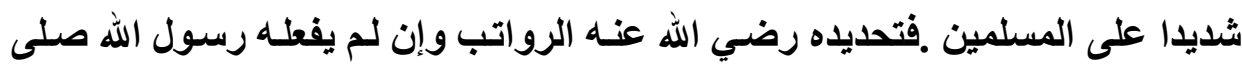
الله عليه وسلم لعدم الحاجة إليه ،لأن الوظائف كانت قليلة على عهده خاصة السياسية منها لضيق الرقعة ،فهو ملائم لمقصود الشارع على خلافة سيدنا عمر رضي الله عنـه

$$
\text { () للحاجة إليه }
$$

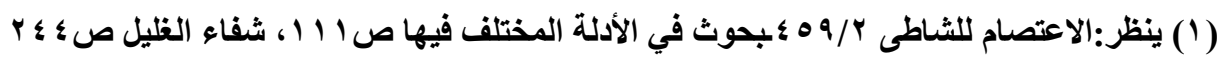

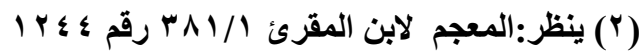

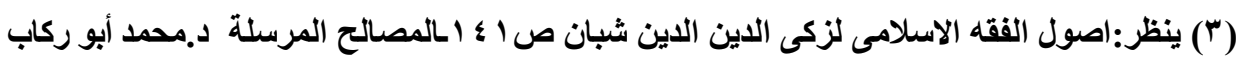




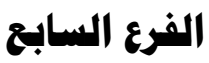

\section{إلزام الناس بحمل الهويات الشخصية أو العائلية}

فإلزام الناس بحمل الهويات الثخصية أو العائلية ،و إلزامهم بقو اعد خاصة في استخراج جواز السفر والخروج من البلاد ودخولها وغير ذلكك من الأمور التي سكت

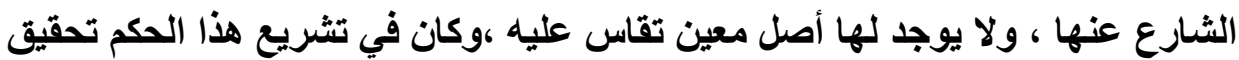

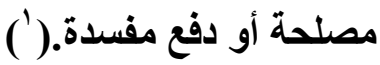

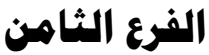

\section{إذا خلا الزهان عن هجتهد}

اتفق العلمـاء علـى أن الإمامسة الكبرى لا تنعقد إلالمـن نـال رتبـة الاجتهـاد

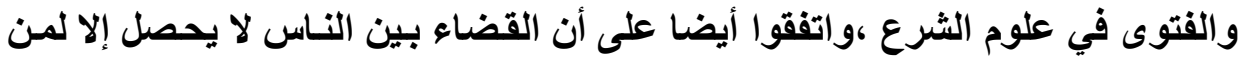

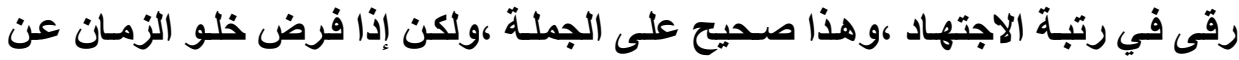

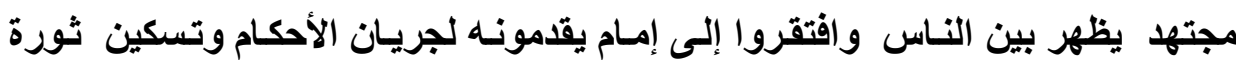

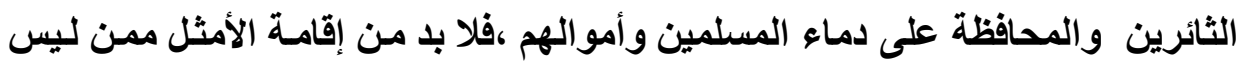
بمجته ،لأنتا بين أمرين

أحدهما :إما أن يترك الناس فوضى وهو عين الفساد والهرج.

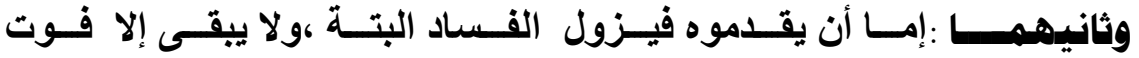

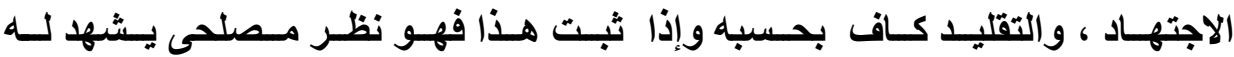

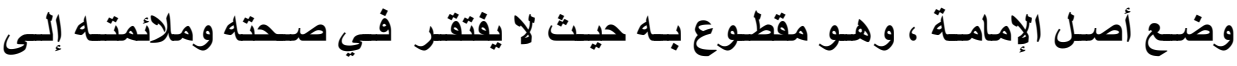


هذا :وان كان ظاهره مخالفا،لما نقلوه من الإجماع في الحقيقة إنمـا نعقد على مانى

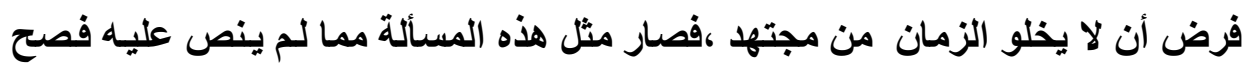

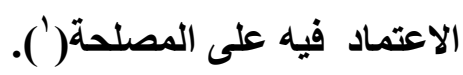

\section{الفرع التاسع}

\section{أن عمر أبقى الأرض الافتوحة في أيدي أهاهـا}

إن عمر بن الخطاب لم يقم بتوزيع الأراضي التي غنموها من الأعداء في البلاد

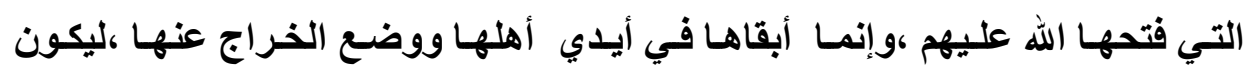
موردا للمسلمين ،وينتفع به الموجودون في ذلك الوقت ومن سيأتي بعدهم ،وقد واققه

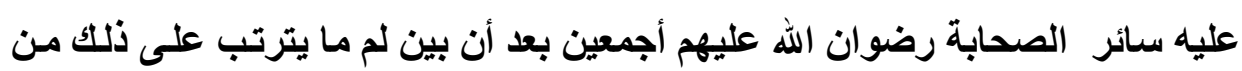

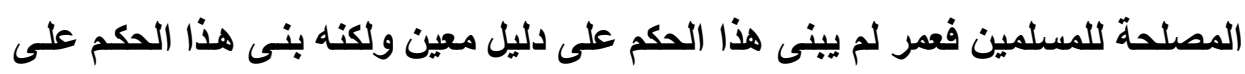
المصلحة المرسلة ()).

\section{الفرع العماشر}

\section{تولية أبو بكر لعهمر الخلافة هن بعده}

إن أبا بكر الصديق رضـي الله عنه عندما أحس بقرب وفاته اختـار عمر ابن

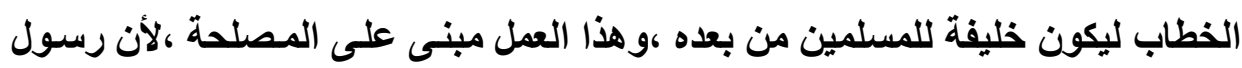
الله صلى الله عليه وسلم لم يستخلف أحدا بعده،ولم يرد عنه شيع في ذللك ، والمصلحة

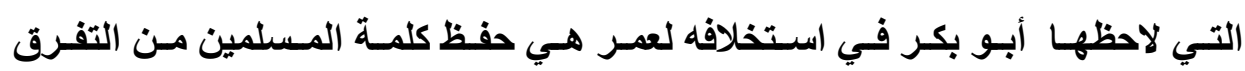
والاختلاف في اختيار الخليفة من بعده وهم في وقت أحوج ما يكونوا إلى وحدة الصف 


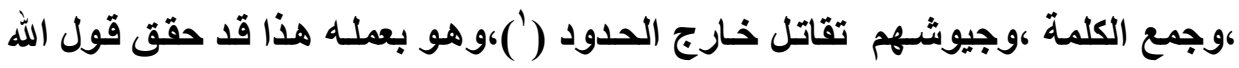
تعالى "واعتصموا بحبل الله جميعا ولا تفرقوا "(Y)وقوله تعالى "ولا تناز عوا فتفشثلوا

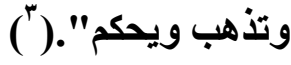

\section{الفرع الحادي عشر}

\section{بيعة المفضول هع وجود الأفضل}

إن تردنا في مبأ التولية بين مجتهد في علوم الشرائع ،وبين متقاصر عنها ،

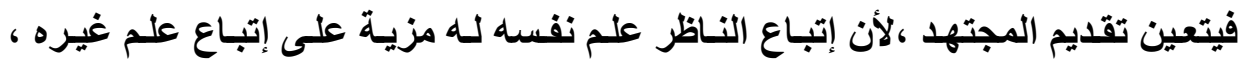

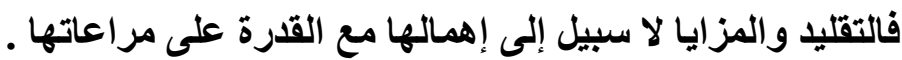

أما إذا انعقدت الإمامة بالبيعة أو تولية العهد لمنفك عن رتبة الاجتهاد ،وقامت

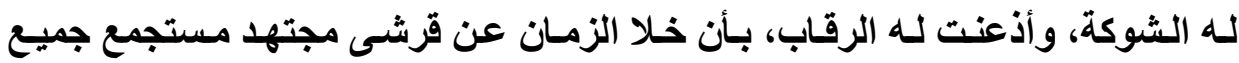
الشر ائط وجب الاستمرار.

وإن قدر حضور قرشسي مجتهـ مستجمع للفروع و الكفايـة ،وجميع شـرائط

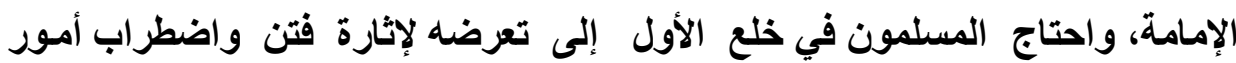

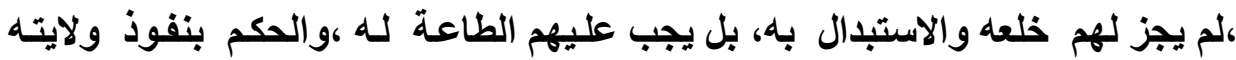

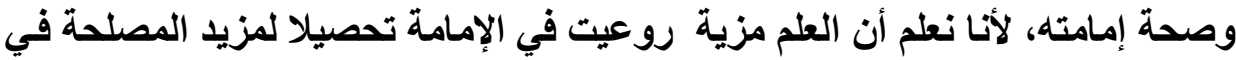

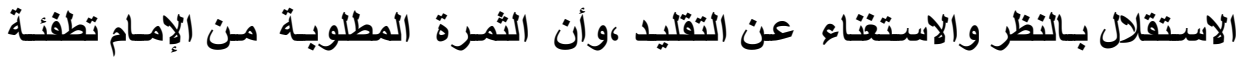

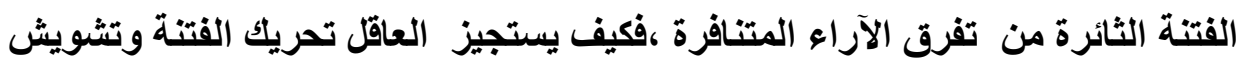

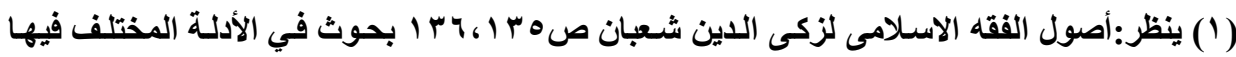

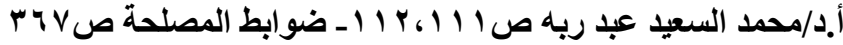

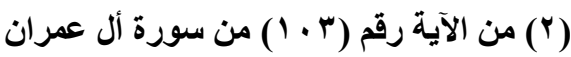
(بآ) من الآية رقم (1) \&) من سورة الأنفال 
النظام وتفويت أصل المصلحة في الحال تثوفا إلى مزيـ دقيقة في الفرق بين النظر

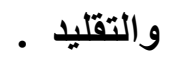

وعند هذا ينبغي أن يقيس الإنسان ما ينـال الخلق من الضرر بسبب عدول

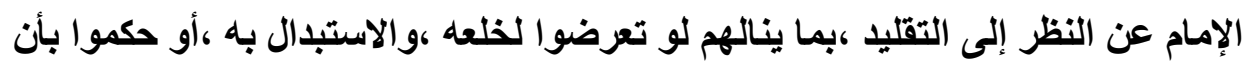
إمامته غير منعقدة . وهذا لم يوجد نص معين يدل عليه ،ولكن مبنـاه على المصلحة ،وهو ملائم

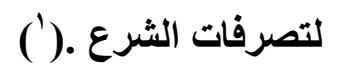




\section{الفرع الأول}

\section{قتل الجماءة بالواحد}

إذا اشترك اثتـان أو أكثر ممن يجب عليهم القصاص في قتل واحد عمدا

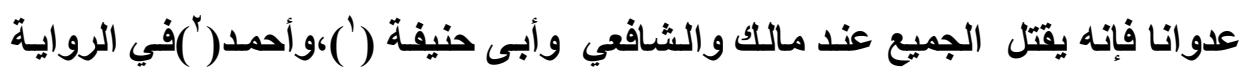
المشهورة عنه .

وهؤلاء استـلوا بالمصلحة المرسـلة حيث إن القصاص لو سقط بالاشتراك لأدى إلى اتساع القتل به، فيؤدى إلى إسقاط حكمة الردع والزجر ،فاقتضت المصلحة

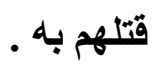

واحتجـوا بغيـر ذلــك كفعل عمـر حيـث قتـل سـبعة برجـل واحــ ،وقــال قولتهـه

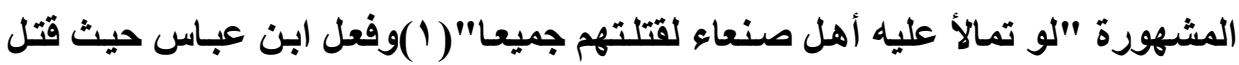
جماعة بواحد .

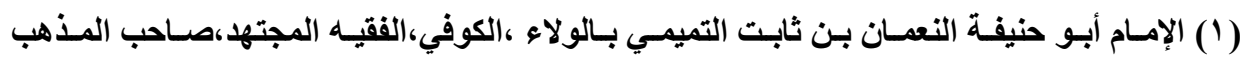

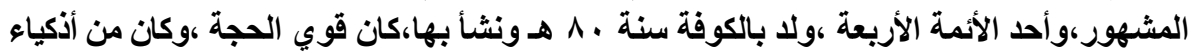

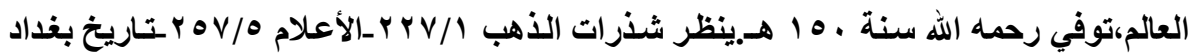

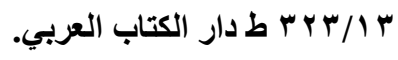

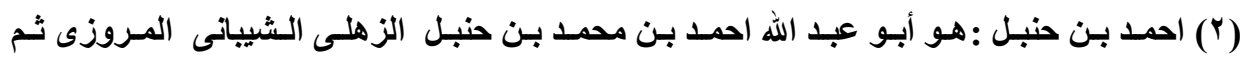

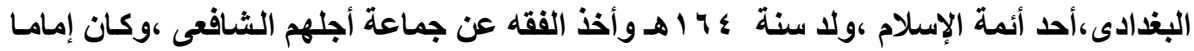

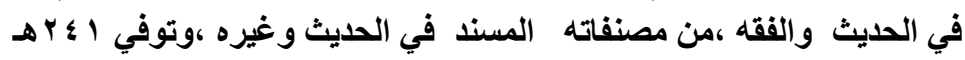

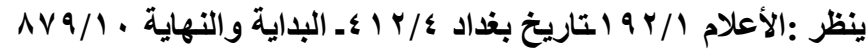


وهنــاك هـذهب ثـان في المسلألة :وهو عدم قتل الجماعـة بالواحد و وإنمـا تجب الدية، وهو مذهب أكثر الظاهريـة،واستلالوا بقوله تعـالى "وكتبنـا عليهم فيها

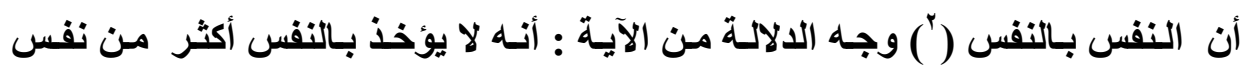
واحدة.

والـراجح: هو المـذهب الأول وذلكك لأن مـا سـتلال بـه أصـحاب المـذهب الثاني وهـو كقولـه وكتبنـا عليهم فيهـا أن النفس بـالنفس ليس نـصا علـي عدم مشروعية

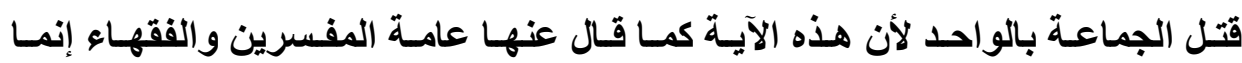
هي إخبار عن شريعة قوم موسى ،والراجح أن شرع من قبلنا ليس شرعا لنا إذ لم يشبت في شرعنا ما يؤيده علي أن الآية ليست في صدد نفي قتل الجماعة بالواحد و إنمـا هي بصدد تعداد أنواع القصاص فمنهـا القصاص بـالنفس ومنهـا بـالأطراف كالعين والأنن فهي إنمـا تنص علي أن قتل النفس يوجب قتل النفس وقطع الأذن يوجب قطع الأذن

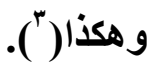

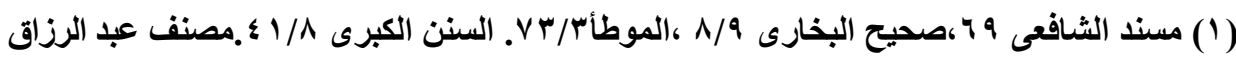

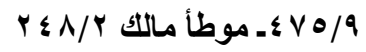

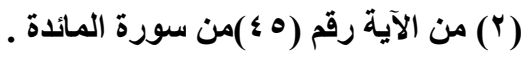

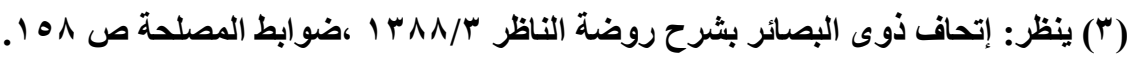

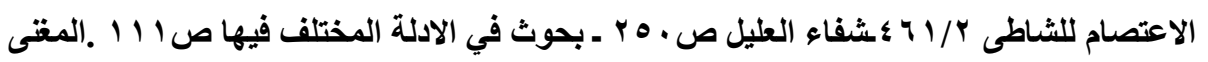

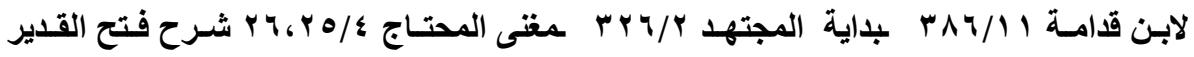




\section{الفرع الثاني}

\section{جلد شارب الخمر ثمانين جلدة}

اتفق أصحاب رسول الله صلى الله عليه وسلم على أن حد شارب الخمر ثمـانين جلدة وكان مستندهم في ذلك الرجوع إلى المصالح والتمسك بالاستـلال المرسل لأن الندان

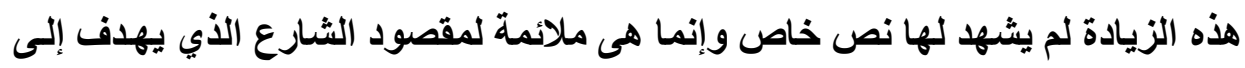

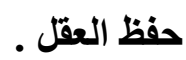

قال العلهماء : لم يكن في زمـان رسول الله حد مقدر،وإنما جرى الزجر فيه مجرى التعزير،ولما انتهى الأمر إلى أبى بكر رضي الله عنه قدره على طـ طريق النظر

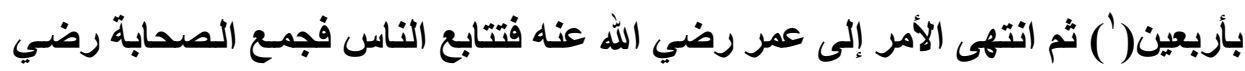
الله عنهم واستثار هم فقال على رضي الله عنه "من سكر هذى ومن هذى الفى الفترى ،

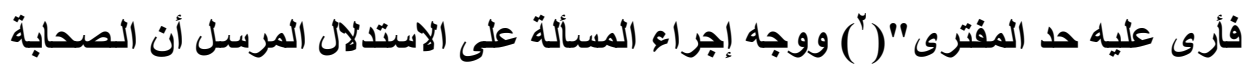

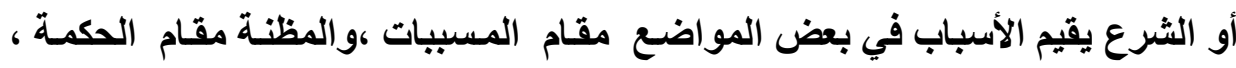

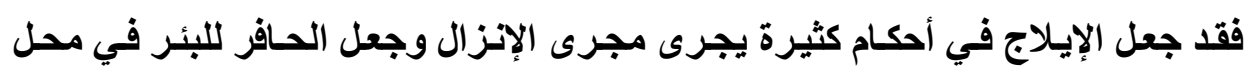

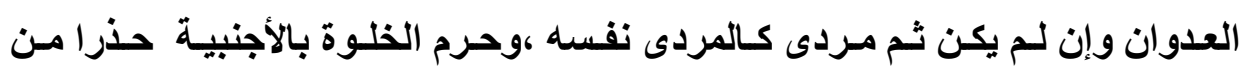
الذريعة إلى الفساد إلى غير ذلك من الفساد ،فرأوا الشرب ذريعة إلى الافتراء الذئي

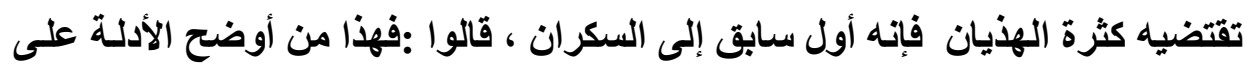

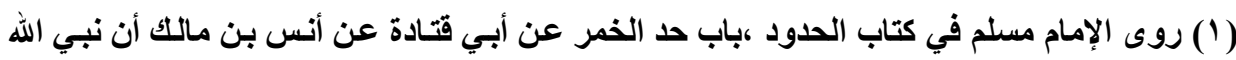

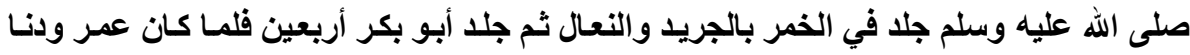

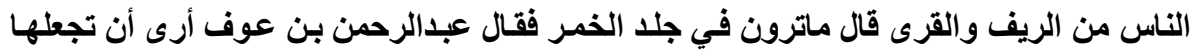

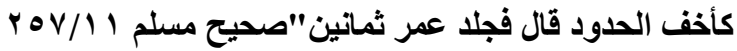

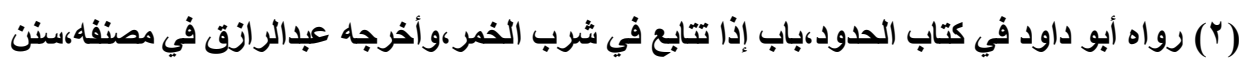

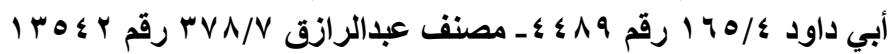


إسناد الأحكام و إلى المعاني التي لا أصول لها (يعنى على الخصوص بـه )وهو مقطوع

من الصحابة رضي الله عنهم.(')

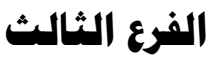

\section{تغريب الزانى البكر}

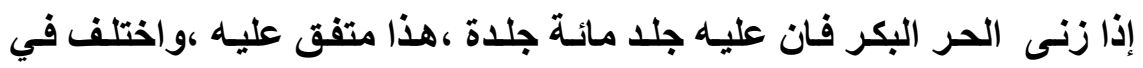

وجوب التغريب عليه مع الجلا على مذاهب .

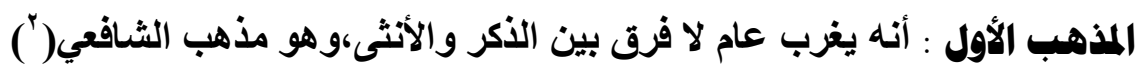

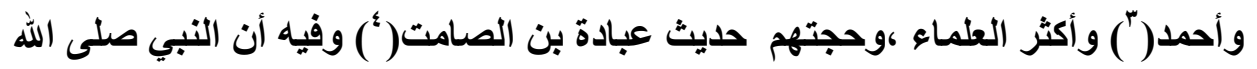

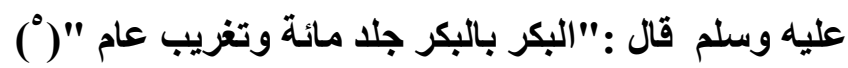

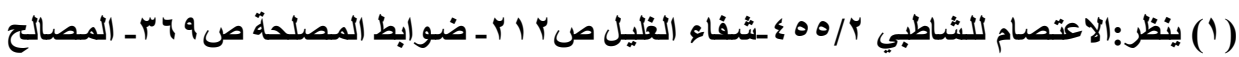

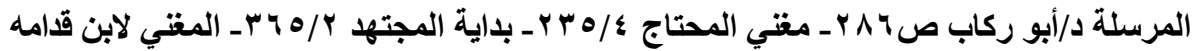

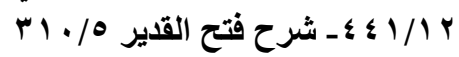

( الثافعي:سبقت ترجمته

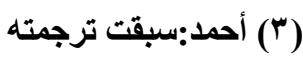

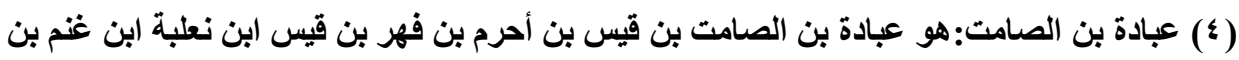

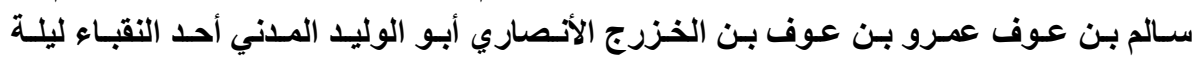

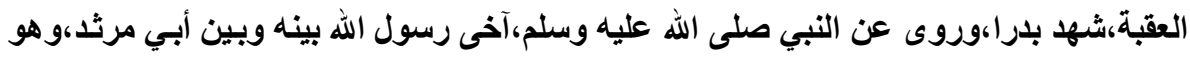

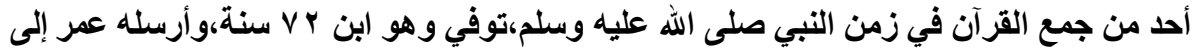

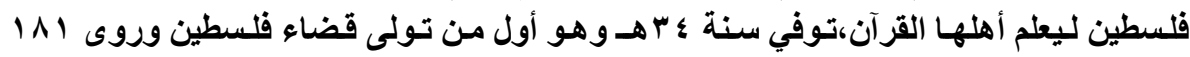

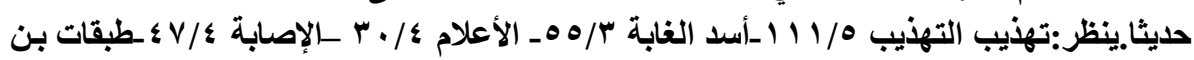
س سعد TVI/V

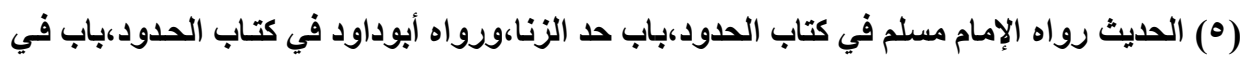

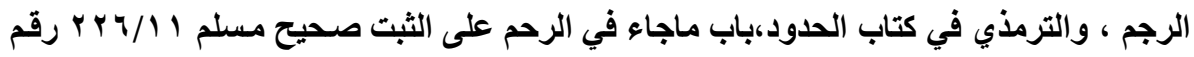

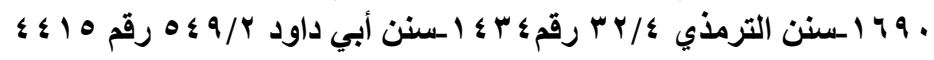

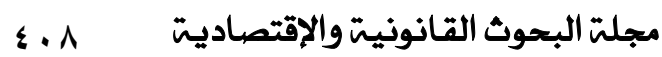


المذهب الثاني:انه لا تغريب على أحد إلا أن يرى الإمسام ذلك ،وهو مذهب أبى

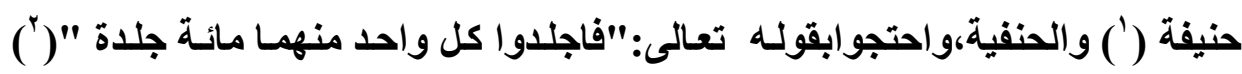

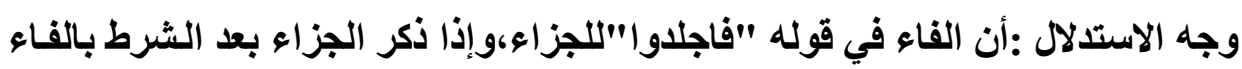
دل على أنه هو الجزاء فقط. وأجابوا عن حديث التغريب بأن العمل به نسخ للكتاب وهو لا يجوز.

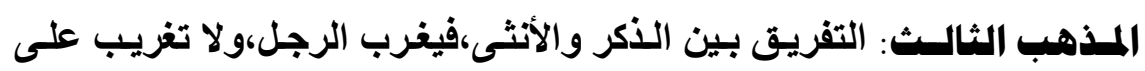

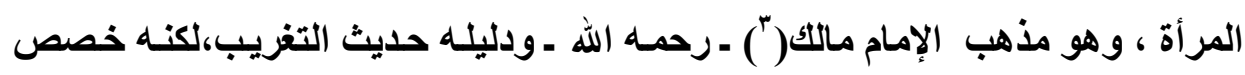

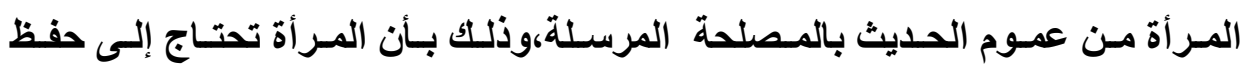

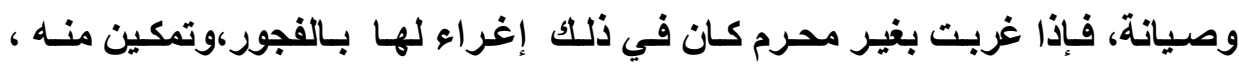

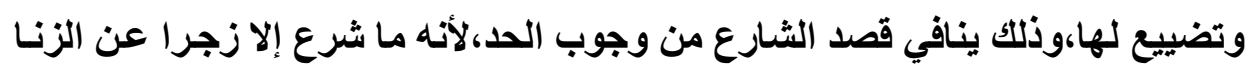

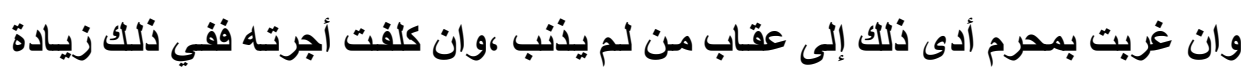

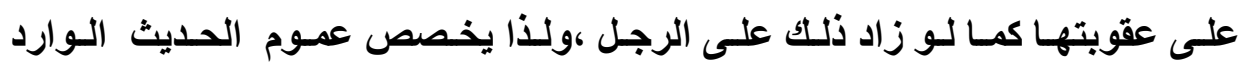

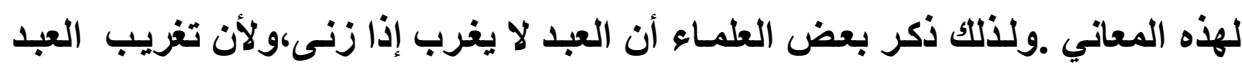

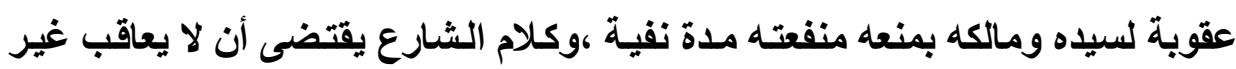

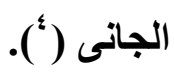

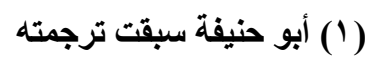

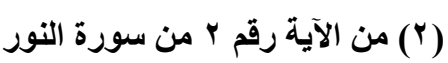

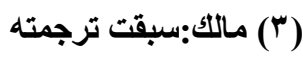

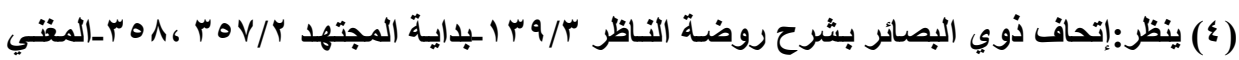

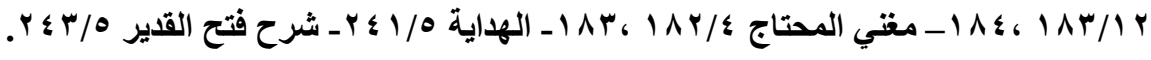




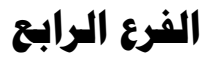 \\ تمليف المدوى عليه}

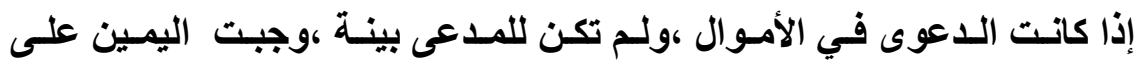
المدعى عليه ،هذا بالاتفاق ،ولكن اختلفوا هل يحلف كل مدعى عليه في هذه الحسال ،أو الو الو لا يحلف إلا من ثبتت بينه وبين المدعى خلطة ؟ على مذهبين:

المذهب الأول:أن اليمين تلزم المدعى عليه بنفس الدعوى مطلقا وهذا مذهب

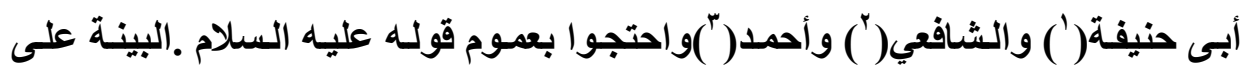
المدعى واليمين على المدعى عليه( (").

المذهب الثاني: أنه لا يحلف المدعى عليه إذا كانت بينه وبين المدعى مخالطة أو ملابسة وهذا مذهب الإمـام مالكث واحتج بالمصلحة المرسلة وذلك حتى لا تتخذ الناس الدعاوى ذريعة إلى القضاء ،فيحصل الأذى لكثير من الناس دون مبرر.(")

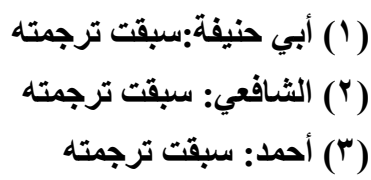

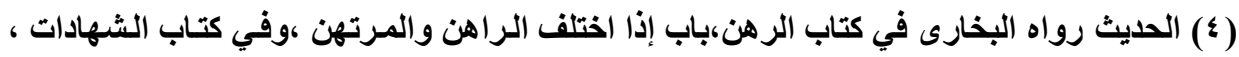

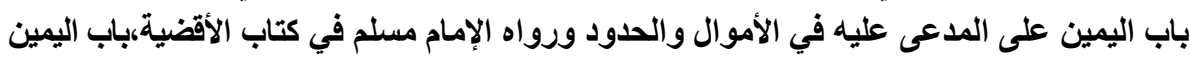

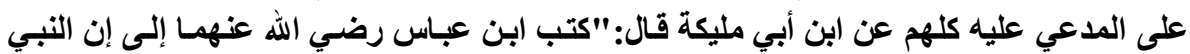

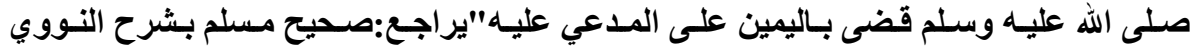

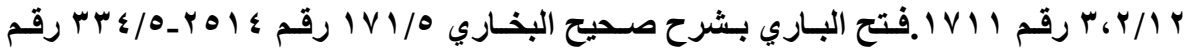

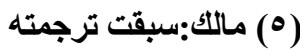

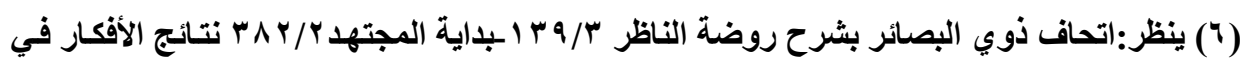

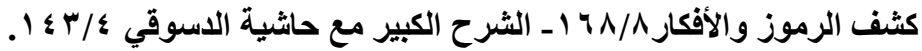

مجلت البحوث القانونيت والإقتصاديت 


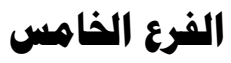 \\ الضرب بآلتهم}

إن العلماء اختلفوا في الضرب بالتهم ،وذهب مالكك إلى جواز السجن في التهم،وان كان السجن نوعا من العذاب ،ونص أصحابه على جواز الضرب، وهو عند

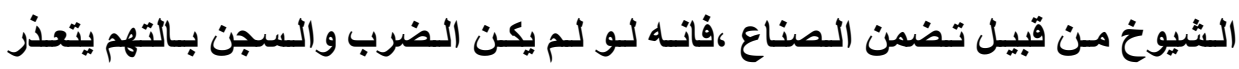

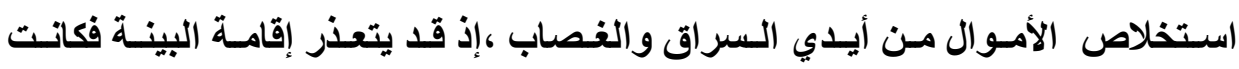
المصلحة في التعذيب وسيلة إلى التحصيل بالتعيين والإقرار. اعترض على ذلك : بأن هذا يفتح باب تعذيب البرئ.

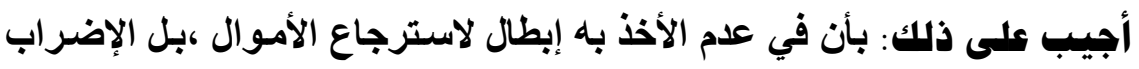

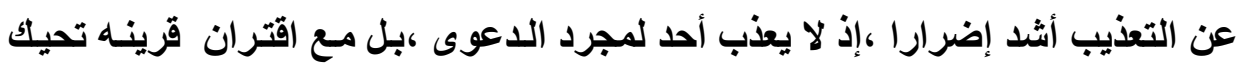

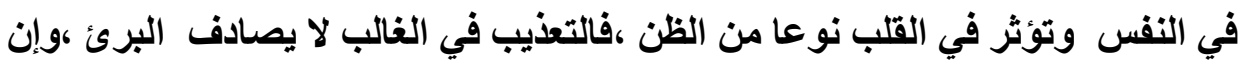

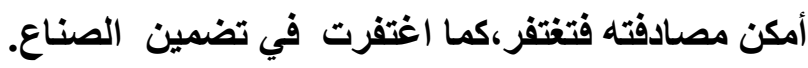
فإن اعترض : بأنه لا فائدة في الضرب ،وهو لو أقر لم يقبل إقراره في تلكت

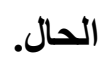

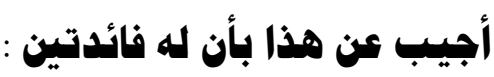

أحدهها : أن يعين المتاع فتثهر عليه البينة لربه ،وهى فائدة ظاهرة .

ثانيهها: أن غيره قد يزدجر حتى لا يكثر الإقدام ،فتقل أنواع هذا الفساد.(')

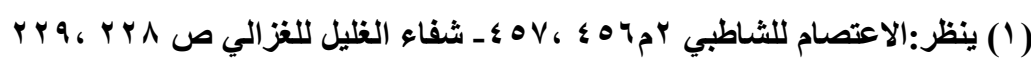




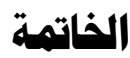

\section{في أهم النتائج والتوصيات}

1- من خلال دراسة هذا الموضوع تبين لنا أن المصلحة ـ كالمنفعة وزنا ومعنى ،

وأنها تطلق على الفعل الذي فيه صلاح بمغنى النفع.

r- إن المصلحة في اصطلاح العلمـاء عبارة في الأصل عن جلب منفعة أو دفع

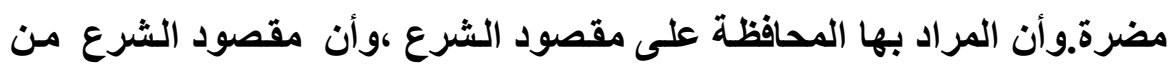

الخلق خمسة أن يحفظ عليهم دينهم ،وأنفسهم ،وعقلهم ،ونسلهم ، ومالهر.

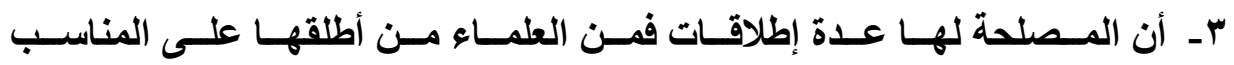

المرسل،ومنهم من أطلقها على الاستصلاح،ومنهم من أطلقها على الاستدلال.

ع - إن مجال العمل بالمصلحة المرسلة إنمـا يكون في الأمور العادية أي فيمـا يتعلق

بمعاملة الناس بعضهم مع بعض.

هـ - إن المصلحة تنقسم باعتبار قوتها إلى ضرورية،حاجية،تحسينية،ومن حيث اعتبار

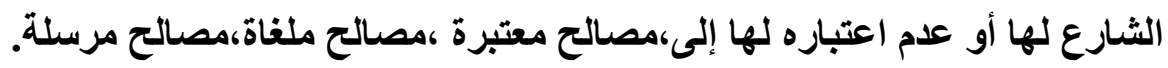

ج- إن المصالح المرسلة هي التي لم يقم دليل من الثارع على اعتبارهـا ولا على إلغائها،وإن سميت بذلك لأن الثارع أطلقها فلم يقيدها باعتبار ولا إلغاء.

V- - - إن العلماء اختلفوا في الاحتجاج بها واعتبارها دليلا شرعيا على مذاهب:فمنهم

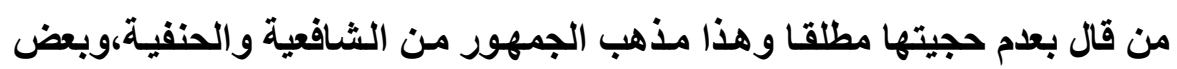
المالكية،ومنهم من قال بأنها حجة إذا تو افرت فيها الثروط التالية:

أــ أن تكون من المصالح المحققة غير المتوهمة. 


$$
\begin{aligned}
& \text { بـ أن لايقوم دليل شرعي يال على إلغائها. } \\
& \text { ج- أن تكون المصلحة من المصالح العامة. } \\
& \text { دـ أن تكون المصلحة معقولة في ذاتها. }
\end{aligned}
$$

هـ أن يكون في الأخذ بها رفع حرج لازم بحيث لو لم يؤخذ بها لوقع الناس في

$$
\text { حرج وضيق. }
$$

وهذا المذهب منسوب للإمام مالك،ونقل أيضا عن الإمام الثافعي.

ومنهم من قال بأن المصالح المرسلة حجة إذا تو افرت فيها شروط ثلاثة وهي أن

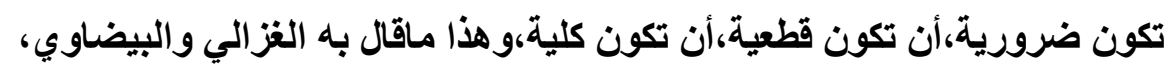

^- إن الراجح من المذاهب هو المذهب الثالث القائل بأن المصالح المرسلة حجة إذا

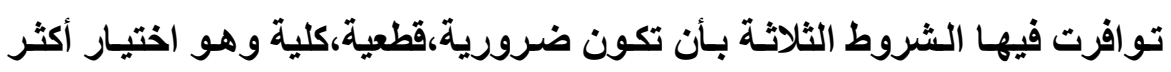

$$
\text { الأصوليين من الأوائل ، والمتأخرين. }
$$

9- بيان أوجه الاتفاق والاختلاف بين المصالح المرسلة والقياس وكذلك بيزها وبين

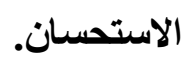

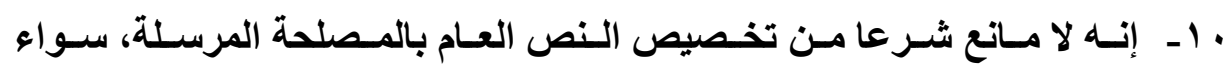
اعتبرناها دليلا مستقلا أو داخلة تحت باب القياس بمفهومها الواسع.

11- بالبحث في هذا الموضوع و التعقى فيه تبين أنها تعالج كثيرا من القضايا التي تجد في حياة المسلمين سياسية كانت أو اقتصادية أم ثقافية أم اجتماعية لأن النيان

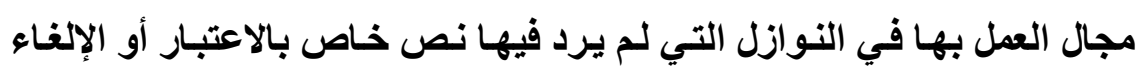

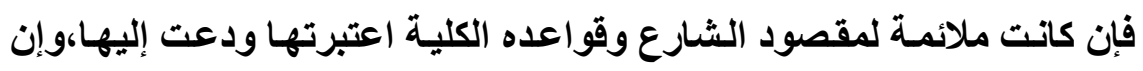

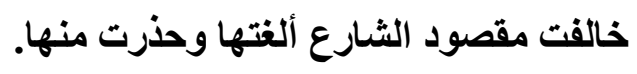




\section{أهم المراجع في البحث}

أولا: القرآن الكريم.

ثانيا:كتب الحديث وعلومهه.

1- السنن الكبرى لإمام المحثثين أبي بكر أحمد بن الحسن بن علي البيهقي المتوفي

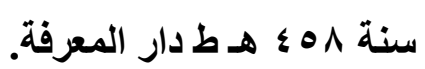

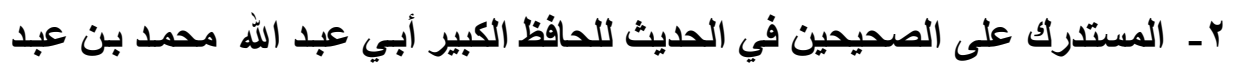

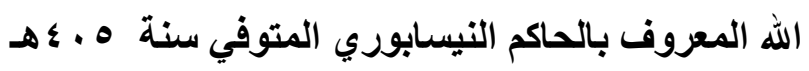

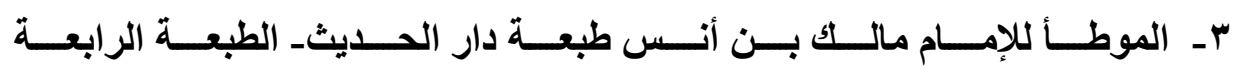

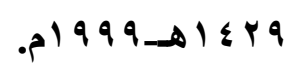

؛ - سنن ابن ماجة للحافظ أبي عبد الله محمد بن يزيد القزويني ابن ماجة المتوفي سنة ه P ه تحقيق محمد فؤاد عبدالباقي طبعة دار الحديث.

هـ سنن الترمذي لأبي عيسى محمد بن عيسى بن سورة تحقيق محمد فؤاد عبد

$$
\text { الباقي طبعة دار الحديث بالقاهرة. }
$$

צ- سنن أبي داود للحافظ أبي داوود سليمان بن الأثعث السجستاني الأزدي المتوفي

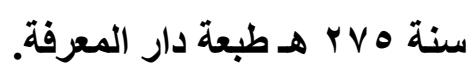

V - Vحيح مسلم بشرح النووي للإمام مسلم بن الحجاج طبعة مكتبة الاعوة بالأزهر.

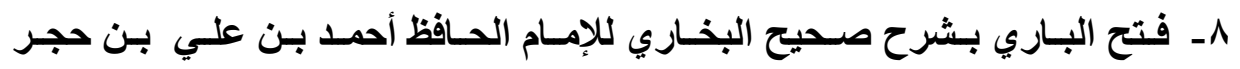
العسقلاني طبعة مكتبة الإيمان بالمنصورة. 9 ــ مسند الإمام أحمد بن حنبل طبعة المكتب الإسلامي. 
ـ 1 ـ مصنف عبد الرازق لأبي بكر عبد الرازق بن همـام الصنعاني طبعة المكتب

$$
\text { الإسملامي. }
$$

11 - مصنف ابن أبي شيبة في الأحاديث والآثار للحافظ عبد الله بن محمد بن أبي

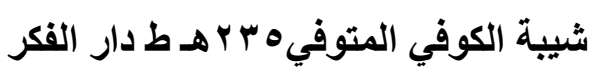

r ا ـ المعبم لابن المقرئ أبي عبد الرحمن عـادل بن سـد طبعة الرشـ الريـاض-

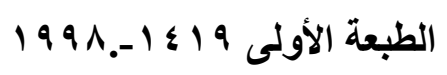

ثالثا:كتب الفقهه:- - مت

1 ـ العناية على الهداية للإمام كمال الدين محمد بن عبد الواحد السيواسي،ثم السكنري

المعروف بابن الهمام الحنفي المتوفي سنة اله 1 اج هـ طبعة دار الفكر.

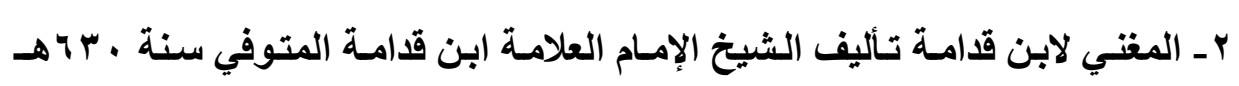
ويليه الشرح الكبير تأليف الإمام ابن قدامة المقدسي المتوفي سنة بـ 1 هـ طبعة الإنة

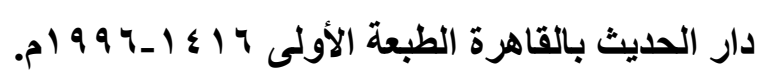

بـ بداية المجتهد ونهاية المقتصد للإمام أبو الوليد محمد بن احمد بن محمد بن احمد

$$
\text { بن رشد القرطبي الأندلسي طبعة دار الفكر. }
$$

ع ـ حاشية الاسوقي على الشرح الكبير للعلامة محمد بن عرفة الدسوقي على الشرح

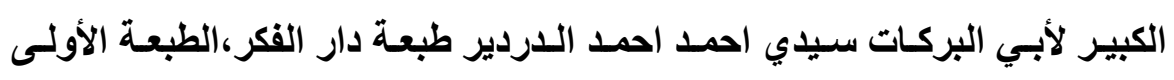

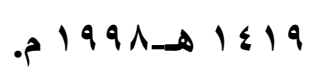

هـ شـرح فتح القدير تـأليف الإمسام كمسال الدين محمد بـن عبدالواحد السيواسي ثم

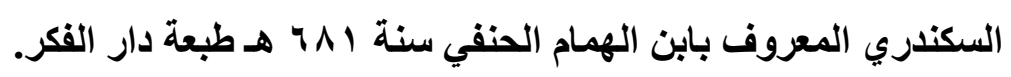




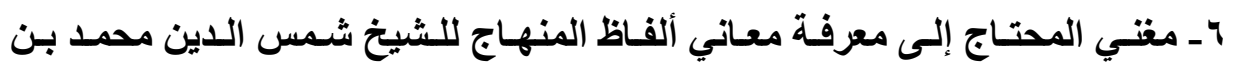
الخطيب الثربيني طبعة دار الفكر الطبعة الأولى 9 1 ـ 1 هـــ9 9 ام.

V- نتائج الأفكار في كشف الرموز والأسرار لشمس الدين احمد بن قودر المعروف بقاضي زاده أفندي قاضي عسكر رومللى وهي تكملة فتح القدير للمحقق الكمـال ابن الههام الحنفي، ط دار الفكر.

\section{رابعا :كتب أصول الفقه:}

1 ـ المنخول من تعليقات الأصول للإمام أبي حامد محمد بن محمد بن محمد الغزالي

$$
\text { طبعة دار الفكر. }
$$

r - الإحكام في أصول الأحكام للإمام علي بن محمد الآمدي تعليق عبدالرازق عفيفي

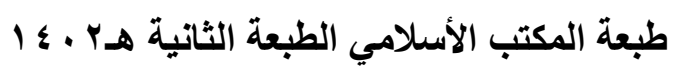

r- المحصول في علم الأصول للإمام فخر الدين محمد بن عمر بن الحسين الرازي

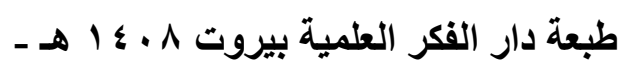

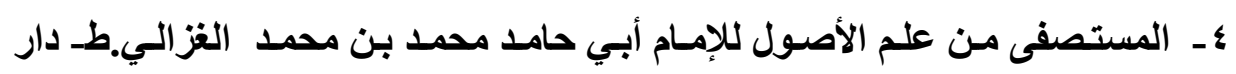

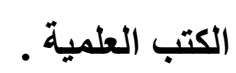

هـ الاعتصام لأبي اسحاق الثاطبي ابراهيم بن موسى اللخمي الغرنـاطي ط ـ المكتبة

$$
\text { التوفيقية. }
$$

4- المسودة في أصول الفقه لآل تيمية طبعة دار الفضيلة.دار ابن حزم الطبعة الأولى

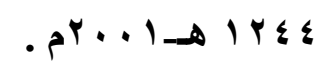

V- الوصف المناسب لشرع الحكم لأحمد الثنقيطىي المكتبة الشاملة 
^ـ شرح تنقيح الفصول اختصار المحصول في الأصول للقرافي طبعة مكتبة الكليات

$$
\text { الأزهرية. }
$$

9 ـ شرح الكوكب المنير المسمى مختصر التحرير او المختبر المبتكر شرح المختصر في أصول الفقه للعلامة محمد بن عبدالعزيز بن علي الفتوحي الحنبلي المعروف بابن النجار طبعة مكتبة العبيكان.

ـ ـ ـ شرح عضد الدين الإيجي على مختصر المنتهى لابـن الحاجب المـالكي طبعة مكتبة الكليات الأزهرية.

11 - ـفاء الغليل في بيان الشبه والمخيل ومسالك التعليل للشيخ الإمام حجة الإسلام أبى حامد الغزالى ط مطبعة الإرشاد بغداد.

r ا - الموافقات في أصول الشريعة لأبي اسحاق الشاطبي وهو ابراهيم ابن موسى اللخمي الغرناطي المالكي المتوفي سنة . Vq هـ ط المكتبة التوفيقية. ب ا - إرشاد الفحول إلى تحقيق الحق من علم الأصول تأليف الإمام محمد بن علي بن

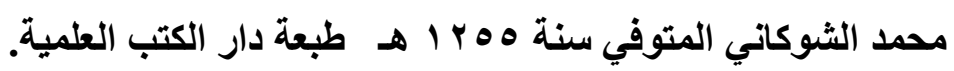

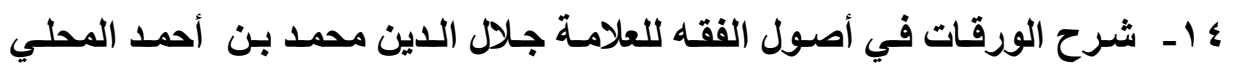
الشافعي المتوفي سنة ؛ ؟ 1 هـ طبعة مكتبة العبيكان. ه 1 ـ شرح مختصر الروضة تأليف نجم الدين أبي الربيع سليمان بن عبدالقوي بن عبدالكريم ابن سعيد الطوفي طبعة مؤسسة الرسالية. 17 - ضوابط المصلحة في الثريعة الإسلامية لمحمد سعيد رمضان البوطي طبعة دار الفكر. 
IV - حاثية العلامة البناني علي شرح الجلال شمس الدين محمد بن أحمد المحلي علي متن جمع الجوامع للإمام تاج الدين عبد الوهـاب ابن السبكي ط ـمصطفي البابي الحلبي وأولاده بمصر .

1 1ـ شرح التلويح علي التو ضيح لمتن التقبيح في أصول الققه للإمـام سـد الدين

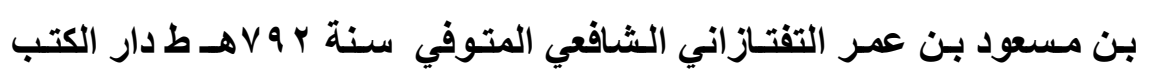

$$
\text { العلمية. }
$$

9 ا ـ ضوابط المصلحة في الشريعة الإسـلامية لمحمد سـعيد رمضان البوطى ط.دار

الفكر

• r- - روضة الناظر وجنة المناظر في أصول الفقه على مذهب الإمـام احمد بن حنبل

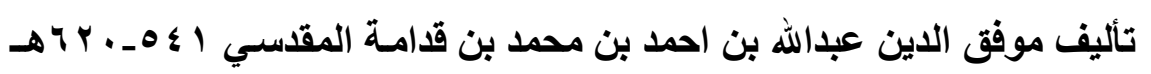

$$
\text { طبعة مكتبة الرشد-الرياض. }
$$

ابـ ـ تخريج الفروع على الأصول للإمام أبي المناقب شـهاب الدين محمود بن أحمد

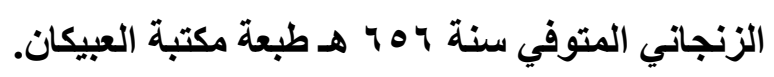

Y Y - المختصر في أصول الفقه على مذهب الإمام أحمد بن حنبل تأليف أبي الحسن علاء الدين علي بن محمد بن علي بن عباس البعلي المعروف بـابن اللحسام

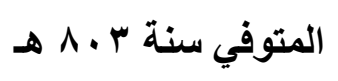

r r - المدخل إلى مذهب الإمام أحمد بن حنبل تأليف الشيخ عبدالقادر بن احمد بن مصطفى المعروف بابن بدران طبعة دار الكتب العلمية.

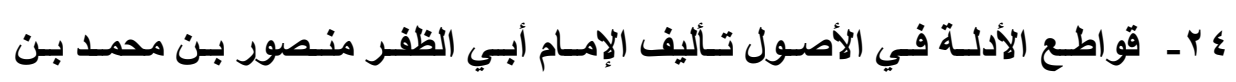

عبدالجبار السمعاني المتوفي 9 ه ـ هـ طبعة دار الكتب العلمية. 
ه بـ ـ لباب المحصول في علم الأصول للعلامـة الحسين بن رشيق المـالكي المتوفي سنة ب r ج هـ طبعة دار البحوث للاراسات الإسلامية وإحياء التراث. צr - كثف الأسرار عن أصول البزدوي تأليف الإمام علاء الدين عبد العزيز بن أحمد البخاري المتوفي سنة . V هـ ط .دار الكتب العلمية. rV - مختصر المنتهي ومعه شرح عضد الدين الإيجي للإمام ابن الحاجب المـالكي ط.

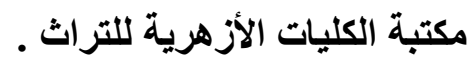
A Y - نهاية السول للإمام جمال الدين عبد الرحيم الإسنوى المتوفي VVY هـ شرح منهاج الوصول في علم الأصول تأليف القاضسي البيضاوي المتوفي سنة هـ هـ طبعة دار الكتب العلمية .

q بـ نبراس العقول في تحقيق القياس عند علماء الأصول للمؤلف عيسى منون ط.

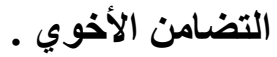

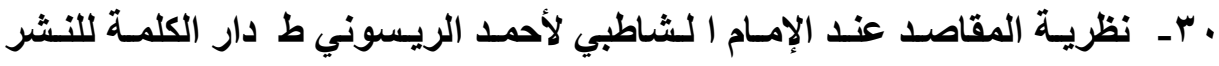
والتوزيع .

ابــ أصـول الفقه للأسـتاذ الـكتور محمــ أبـو النـور زهير طبعة المكتبـة الأزهريـة للتراث. r r - أصول الفقه الإسلامي د: زكي الدين شعبان ط الكتاب الجامعي. ب بــ المصالح المرسلة وأثرها في مرونة الفقه الإسلامي تأليف الدكتور محمد محمد أبو ركاب طبعة دار البحوث للاراسات الإسلامية وإحياء التراث. ع بـ- علم أصول الفقه للأستاذ الدكتور عبدالوهاب خلاف طبعة دار الحديث. هـ- الاستدلال المصالح المرسلة للاكتور سعد بن مطر العتيبي. 
צr- المصلحة المرسلة وتطبيقاتها المعاصرة للاكتور عبدالله محمد صالح.

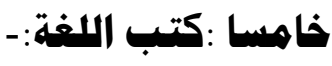

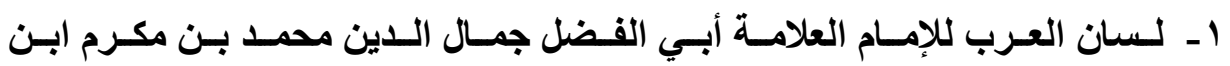

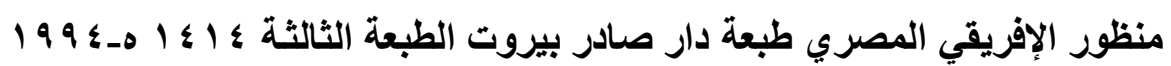

م.

Y - القاموس المحيط للثيخ مجد الدين محمد بن يعقوب الفيروز أبادي طبعة المطبعة

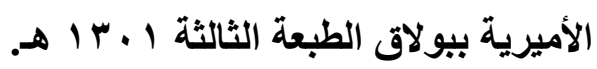

r- المصباح المنير للعلامـة أحمد بن محمد بن علي الفيومي المقري طبعة المكتبة

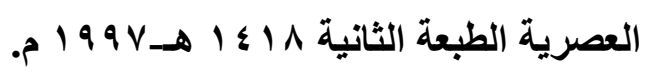

ع - مختار الصحاح للإمام محمد بن أبي بكر بن عبدالقادر الرازي طبعة مكتبة لبنان.

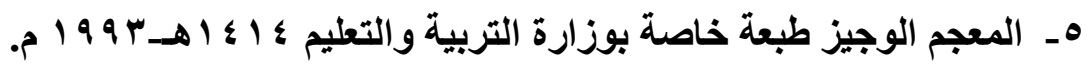

